

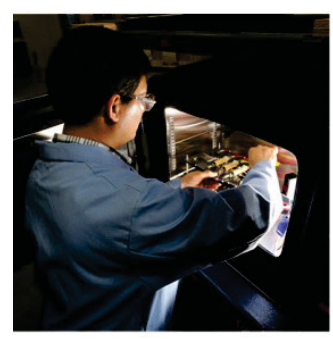

The High Energy Battery Test Facility at the Energy Systems Laboratory houses over 650 battery test channels, environmental chambers, a shake table, and related battery testing equipment and test vehicle platforms for evaluating new battery technologies under development for automotive applications.

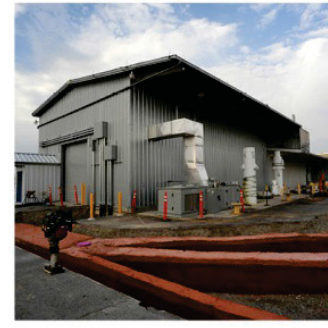

A portion of the new electrical distribution loop to provide double-ended feed for all facilities on the north side of MFC. The Experimental Fuels Facility (shown) is one of the R\&D facilities benefitting from this power expansion.

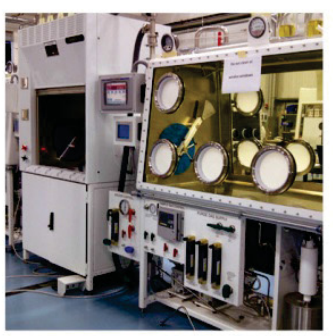

Transuranic Suveillance Glovebox being installed in Fiscal Year 2013 will establish a work platform providing radiological containment and an inert atmosphere to perform surveillance and repackaging of transuranic material in the Zero Power Physics Reactor

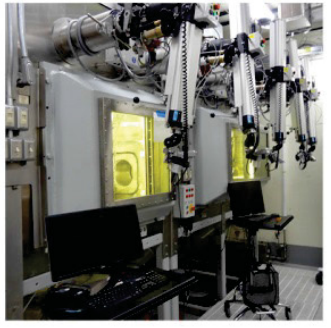

Shielded hot cells in the Fuel and Applied Science Building at the Materials and Fuels Complex protect workers from highly radioactive test specimens during irradiation assisted stress corrosion and cracking tests and post-test examinations.

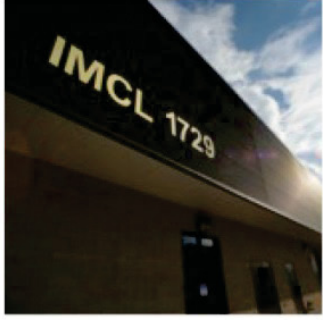

The Irradiated Materials

Characterization Laboratory at the Materials and Fuels Complex provides reconfigurable space for using a variety of instruments and equipment to analyze and characterize irradiated fuel and structural components.

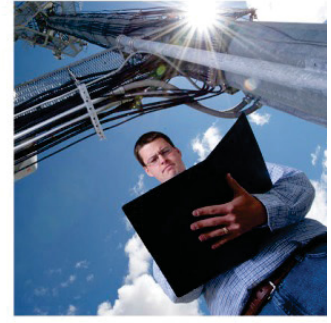

The unique capabilities at the Wireless Test Bed National User Facility enable industrial, federal, and academic researchers to address national challenges in infrastructure security, communications interoperability, spectrum utilization, and the reliability of wireless technologies. 


\section{Idaho National Laboratory 2015-2023 Ten-Year Site Plan}

September 2013

Prepared for the 


\section{Idaho National Laboratory}

\section{5-2023 TEN-YEAR SITE PLAN}
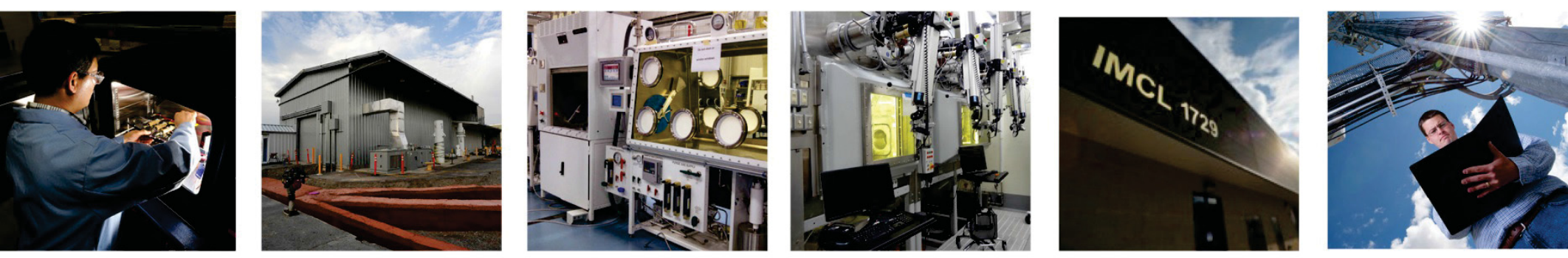

Developing and Maintaining the

INL Infrastructure

September 2013

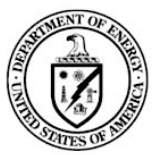

YIIdaho National Laboratory 


\section{APPROVALS}

Idaho National Laboratory

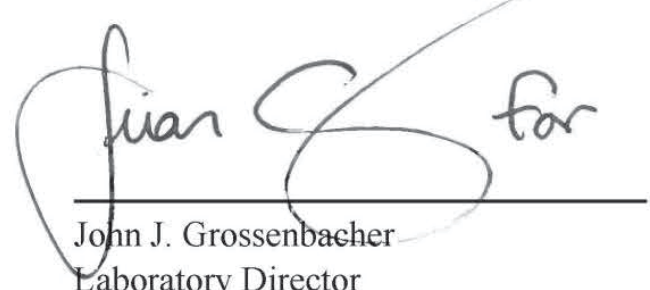

Laboratory Director

Idaho National Laboratory

President and Chief Executive Officer

Battelle Energy Alliance, LLC

\section{U.S. Department of Energy} Idaho Operations Office

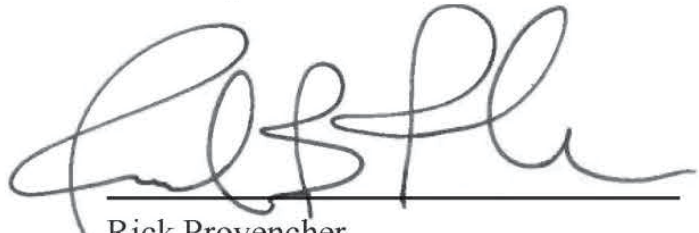

Rick Provencher

Manager

Idaho Operations Office

U.S. Department of Energy

\section{U.S. Department of Energy}

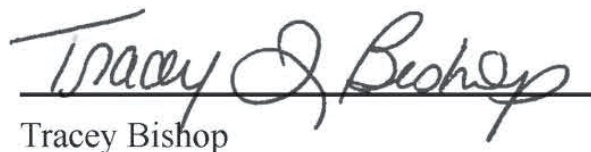

Acting Deputy Assistant Secretary

for Nuclear Facility Operations

U.S. Department of Energy 


\section{INL-AT-A-GLANCE}

\section{Location:}

Idaho Falls, Idaho

Type:

Multiprogram Laboratory

\section{Lead Program Secretarial Office:}

U.S. Department of Energy Office of Nuclear Energy

\section{Contractor:}

Battelle Energy Alliance, LLC

Responsible Site Office:

U.S. Department of Energy Idaho Operations Office

\section{Website:}

http://www.inl.gov/

DOE-NE Physical Assets (FY 2012 FIMS nonprogrammatic owned and operating assets):

- Land Area: 569,178 Acres

- 285 Buildings and Trailers, 2,276K Gross Square Feet

- 200 Nonprogrammatic Other Structures and Facilities

- Replacement Plant Value: $\$ 2,849 \mathrm{M}$

- Deferred Maintenance: $\$ 50.4 \mathrm{M}$

- Asset Condition Index:

All Assets: 0.982 (Target 0.950)

Mission Critical: 0.998 (Target 0.970)

Mission Dependent: 0.964 (Target 0.925)

Non Mission Dependent: 0.939 (Target 0.900)

Human Capital (as of April 8, 2013):

- 3,602 Full-Time Equivalent Employees

- 120 National Scientific User Facility Participants

- 10 Postdoctoral Researchers

- 19 Graduate Student Interns

- 16 Undergraduate Student Interns

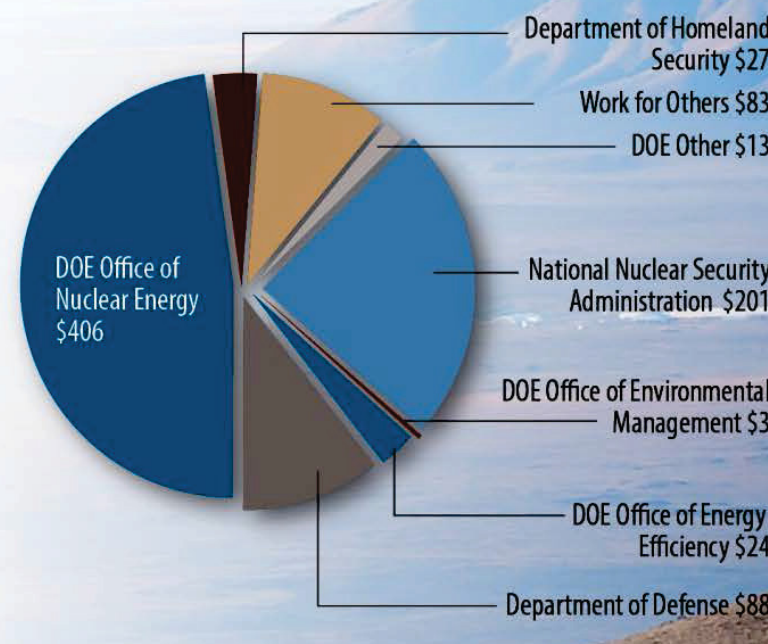

\section{FY 2012 INL FUNDING BY SOURCE (\$M):}

Department of Homeland
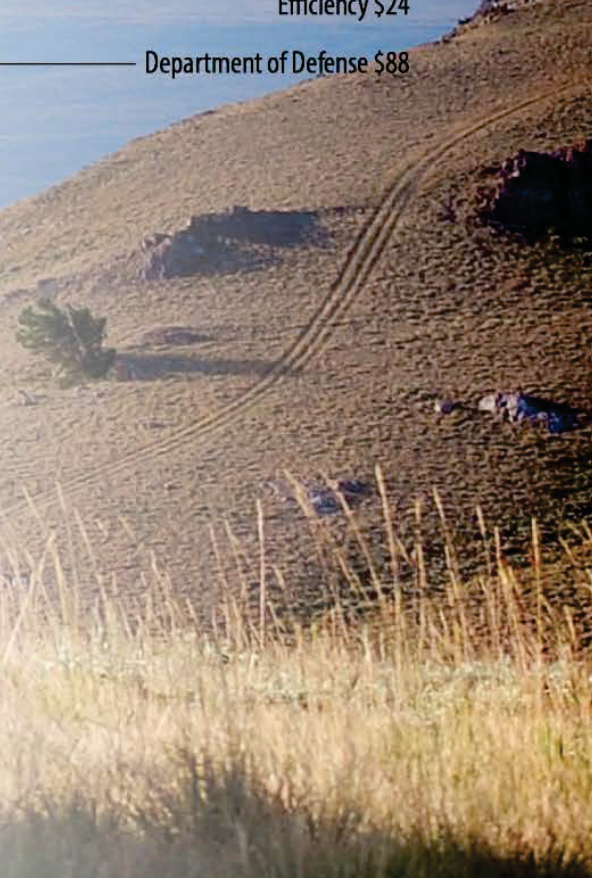


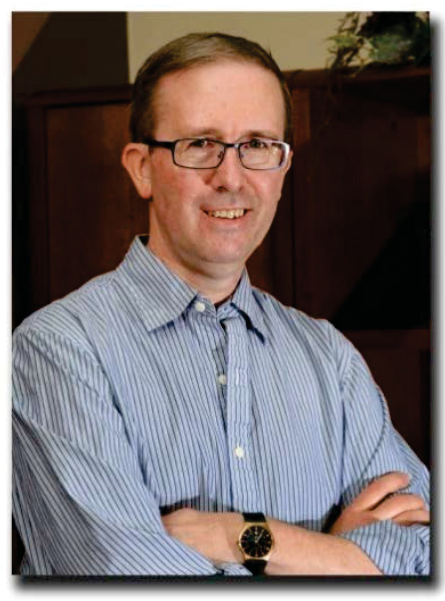

The Idaho National Laboratory (INL) has experienced a significant transformation since 2005. Beginning with an investment to stabilize the general site infrastructure and a major investment in the Advanced Test Reactor (ATR) and its ancillary capabilities, INL has focused more recently on enhancing and investing in capabilities at the Materials and Fuels Complex. Overall, the laboratory has made the most important investments needed to support the Department of Energy's nuclear energy mission while also positioning itself to better support the needs of U.S. industry. INL has transitioned from a collection of skills and facilities to an integrated set of capabilities resident in a modern campus environment across an 890-square mile site in a remote location. Key INL assets such as ATR, the Hot Fuels Examination Facility, and facilities, capabilities, instruments, and tools - enable a broad range of engineering development, testing, and demonstration in nuclear energy, critical infrastructure protection, national and homeland security, and other clean-energy missions.

The addition of the Center for Advanced Energy Studies in February 2009 and the Energy Systems Laboratory in October 2012, as well as the planned addition of the Research and Education Laboratory in October 2013, are transforming University Boulevard into the modern face of INL. After the removal of aging buildings (including decommissioned reactors) and the addition of a new radiochemistry laboratory, the ATR Complex has a new, fresh look. Changes at the Materials and Fuels Complex include the recent construction of the Irradiated Materials Characterization Laboratory, completion of the Experimental Fuels Facility, and utility upgrades to power and sewer systems.

Hosting national infrastructure alone is no longer sufficient to meet changing national energy supply, environmental, and other security needs in the 21 st century. Making certain INL assets available for use by other entities — such as industry, academia, national laboratories, and agencies beyond INL — is a necessary and proper use of the facilities. To optimize the use of precious national resources, INL embraces the user facility model: not only hosting a capability but also making it available to researchers across the nation. Pairing the best ideas with the best capability must be the goal. Establishing ATR and associated postirradiation capabilities at INL into a national user facility was a first step in this transformation; the Wireless Test Bed is our most recent addition.

Future planned additions of nuclear energy research capability will continue to enhance INL's ability to meet these needs. These include advanced postirradiation examination, fuel cycle research and development capability at the Idaho Nuclear Technology and Engineering Center, and bioenergy capability at the Energy Systems Laboratory

This Ten-Year Site Plan outlines the infrastructure vision for INL for the next decade and describes the facilities needed to accomplish the Department of Energy's mission. The task is to align available infrastructure funding to meet these needs. This document details the plans necessary to accomplish the task and continue the ongoing transformation of INL.

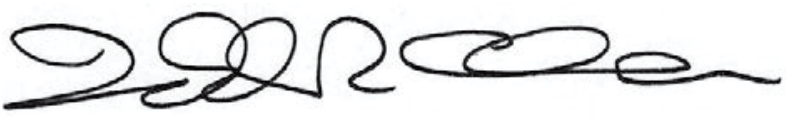

Todd R. Allen

Deputy Laboratory Director,

Science and Technology 


\section{CONTENTS}

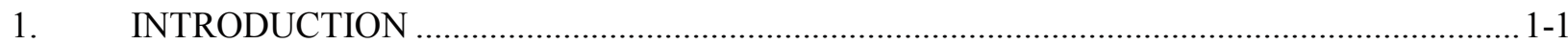

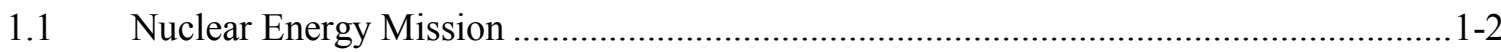

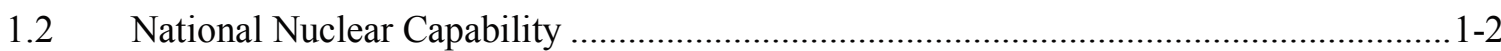

1.3 National and Homeland Security Missions and Capabilities........................................ 1-6

$1.4 \quad$ Energy and Environment Mission and Capabilities....................................................... 1-7

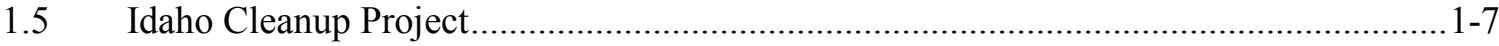

1.6 Advanced Mixed Waste Treatment Project ............................................................ 1-8

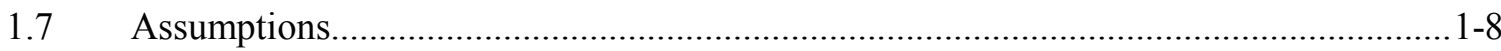

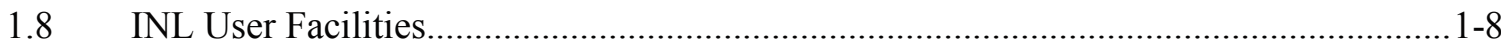

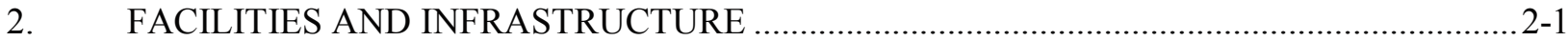

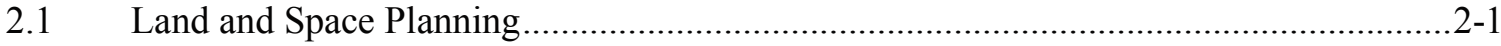

2.2 Idaho National Laboratory Campuses ……...............................................................

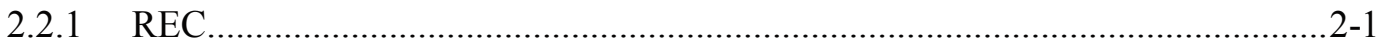

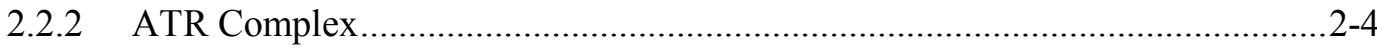

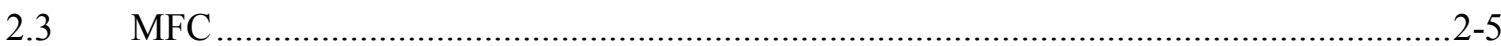

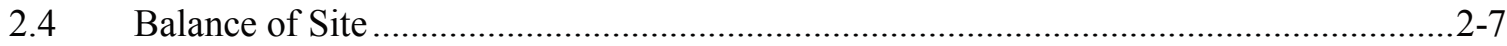

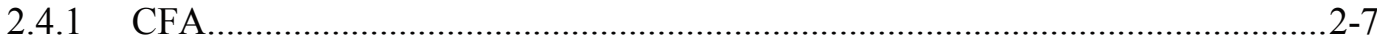

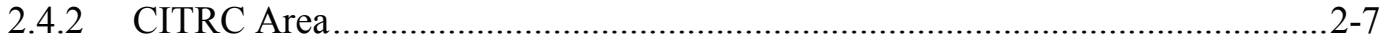

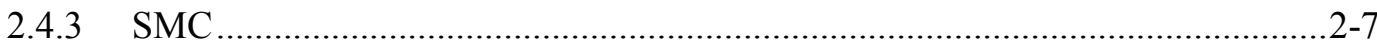

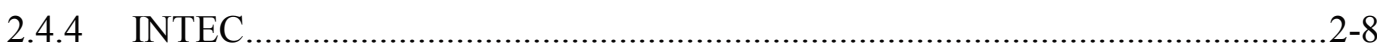

2.5 Idaho National Laboratory Strategic Sustainability ......................................................2-9

3. IDAHO NATIONAL LABORATORY CORE CAPABILITIES ........................................... 3-1

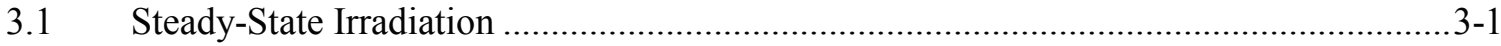

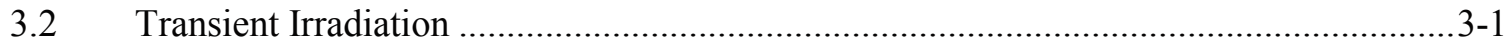

3.3 Fresh Fuel Characterization and Postirradiation Examination....................................... 3-2

3.3.1 Hot Fuel Examination Facility ...................................................................... 3-2

3.3.2 Electron Microscopy Laboratory ............................................................ $3-2$

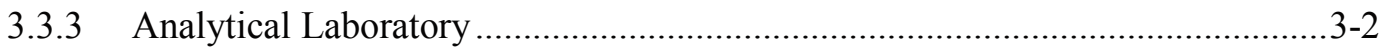

3.3.4 Fuels and Applied Science Building............................................................. 3-3

3.3.5 Irradiated Materials Characterization Laboratory ............................................... 3-3

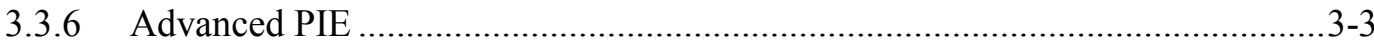

3.3.7 National Scientific User Facility............................................................... 3-3

3.4 Experimental Fuel Fabrication and Process Development ..............................................

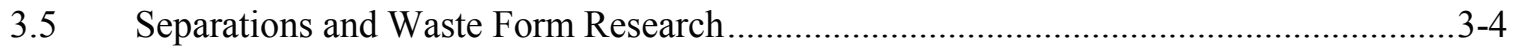




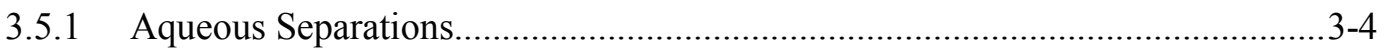

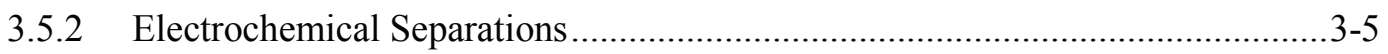

3.6 Used Fuel Storage and Transportation Research, Development, and Demonstration ......3-5

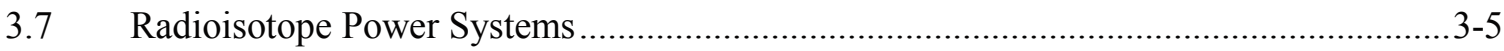

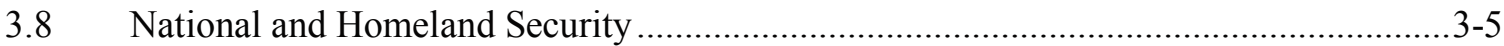

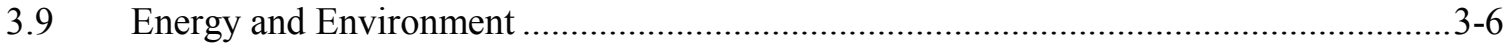

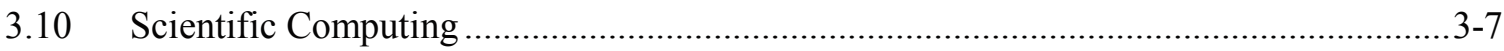

4. IDAHO NATIONAL LABORATORY ENABLING INFRASTRUCTURE ............................4-1

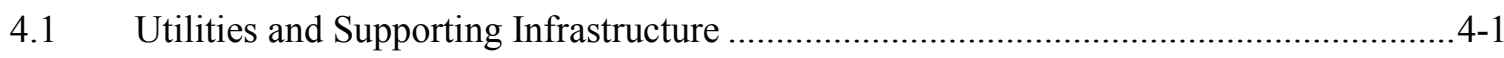

4.2 Nuclear Materials Management Infrastructure ..............................................................4-1

4.3 Waste Management Infrastructure ...........................................................................

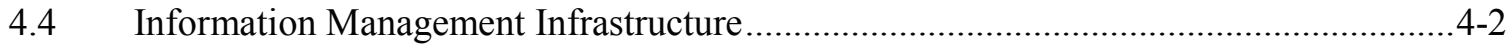

4.5 Laboratory Protection Services Infrastructure …....................................................... $4-2$

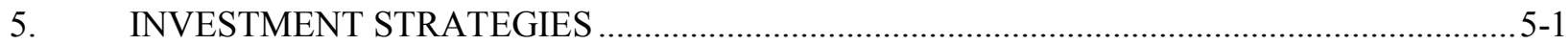

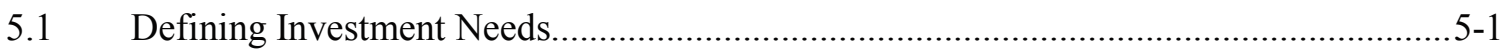

5.2 Investment Approach .................................................................................... $5-4$

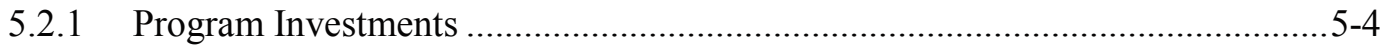

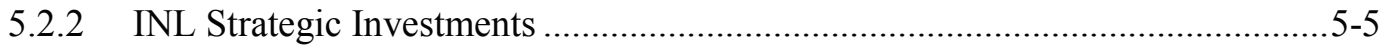

5.2.3 Alternatively Funded Investments …….......................................................5-5

6. CHANGES FROM FISCAL YEAR 2013 TEN-YEAR SITE PLAN …................................... 6-1

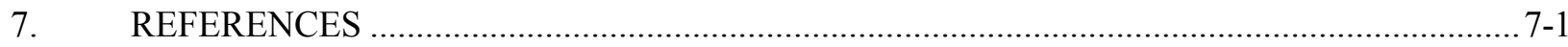

\section{FIGURES}

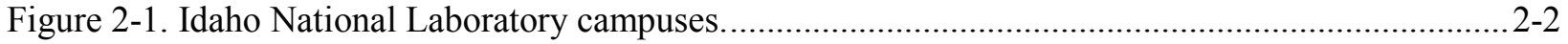

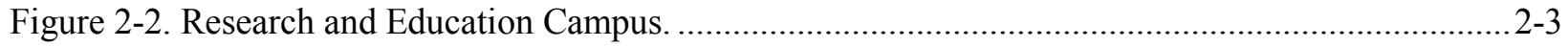

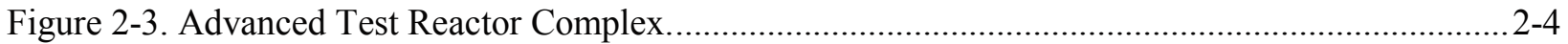

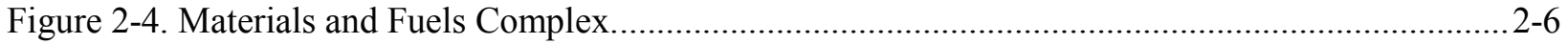

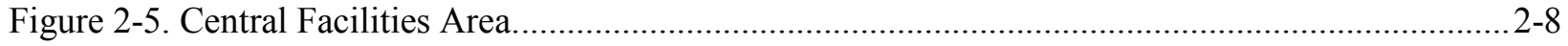

Figure 2-6. Idaho Nuclear Technology and Engineering Center. ........................................................2-9

Figure 5-1. Projected Idaho National Laboratory facilities, sustainment, and disposition needs.............5-4 


\section{TABLES}

Table 1-1. Idaho National Laboratory nuclear energy research and development core physical research capabilities - operational, in progress, or planned.

Table 5-1. Idaho National Laboratory infrastructure gaps.

\section{APPENDICES}

Appendix A: Real Property Asset Management

Appendix B: Prioritized Resource Needs

Appendix C: Cognizant Secretarial Offices, Program Secretarial Offices, and Non-DOE Programs

Appendix D: Strategic Sustainability 


\section{ACRONYMS}

\begin{tabular}{|c|c|c|c|}
\hline $\mathrm{ACI}$ & asset condition index & DRR & domestic research reactors \\
\hline $\mathrm{AL}$ & Analytical Laboratory & DU & depleted uranium \\
\hline \multirow[t]{2}{*}{ AMWTP } & Advanced Mixed Waste & EBR & Experimental Breeder Reactor \\
\hline & Treatment Project & ECM & energy conservation measure \\
\hline ARP & Accelerated Retrieval Project & ECS & Emergency Communication \\
\hline \multirow[t]{2}{*}{ ASME } & American Society of & & System \\
\hline & Mechanical Engineers & $\mathrm{EFF}$ & Experimental Fuels Facility \\
\hline ATR & Advanced Test Reactor & EML & Electron Microscopy \\
\hline \multirow[t]{2}{*}{ ATRC } & Advanced Test Reactor Critical & & Laboratory \\
\hline & (Facility) & EMS & environmental management \\
\hline AUI & asset utilization index & & system \\
\hline BA & Budget Authority & $\mathrm{EO}$ & Executive Order \\
\hline ВCTC & $\begin{array}{l}\text { Bonneville County Technology } \\
\text { Center }\end{array}$ & EPRI & $\begin{array}{l}\text { Electric Power Research } \\
\text { Institute }\end{array}$ \\
\hline BEA & Battelle Energy Alliance, LLC & EROB & Engineering Research Office \\
\hline \multirow[t]{2}{*}{ CAES } & Center for Advanced Energy & & Building \\
\hline & Studies & ESL & Energy Systems Laboratory \\
\hline CAIS & $\begin{array}{l}\text { Condition Assessment } \\
\text { Information System }\end{array}$ & ESPC & $\begin{array}{l}\text { Energy Savings Performance } \\
\text { Contract }\end{array}$ \\
\hline \multirow{3}{*}{$\begin{array}{l}\text { CAM } \\
\text { CERCLA }\end{array}$} & continuous air monitor & FASB & Fuels and Applied Science \\
\hline & Comprehensive Environmental & & Building \\
\hline & $\begin{array}{l}\text { Response, Compensation, and } \\
\text { Liability Act }\end{array}$ & FAST & $\begin{array}{l}\text { Fluorinel Dissolution Process } \\
\text { and Fuel Storage }\end{array}$ \\
\hline CFA & Central Facilities Area & $\mathrm{FCF}$ & Fuel Conditioning Facility \\
\hline \multirow{3}{*}{$\begin{array}{l}\text { CFI } \\
\text { CITRC }\end{array}$} & Conventional Facility Indicator & FCRD & Fuel Cycle Research and \\
\hline & Critical Infrastructure Test & & Development \\
\hline & Range Complex & FDP & Fluorinel Dissolution Process \\
\hline \multirow[t]{2}{*}{ CRADA } & Cooperative Research and & FFTF & Fast Flux Test Facility \\
\hline & Development Agreement & FIB & focused ion beam \\
\hline $\mathrm{CSO}$ & Cognizant Secretarial Office & FIMS & Facility Information \\
\hline CWI & CH2M-WG Idaho & & Management System \\
\hline \multirow[t]{2}{*}{$\mathrm{D} \& \mathrm{D}$} & decommissioning and & FMF & Fuel Manufacturing Facility \\
\hline & demolition & FRR & foreign research reactors \\
\hline \multirow[t]{2}{*}{ DHS } & Department of Homeland & FSV & Fort Saint Vrain \\
\hline & Security & FY & fiscal year \\
\hline $\mathrm{DM}$ & deferred maintenance & GGT & Gas Generation Testing \\
\hline DOD & Department of Defense & GHG & greenhouse gas \\
\hline DOE & Department of Energy & GPP & General Plant Project \\
\hline \multirow[t]{2}{*}{ DOE-EM } & Department of Energy Office of & GSA & General Services \\
\hline & Environmental Management & & Administration \\
\hline \multirow[t]{2}{*}{ DOE-HQ } & Department of Energy & GSF & gross square feet \\
\hline & Headquarters & HEU & highly enriched uranium \\
\hline DOE-ID & $\begin{array}{l}\text { Department of Energy Idaho } \\
\text { Operations Office }\end{array}$ & HEPA & $\begin{array}{l}\text { high-efficiency particulate air } \\
\text { (filter) }\end{array}$ \\
\hline \multirow[t]{2}{*}{ DOE-NE } & Department of Energy Office of & HFEF & Hot Fuel Examination Facility \\
\hline & Nuclear Energy & $\mathrm{HPC}$ & High-Performance Computing \\
\hline
\end{tabular}




\begin{tabular}{|c|c|c|c|}
\hline HPSB & $\begin{array}{l}\text { High Performance Sustainable } \\
\text { Building }\end{array}$ & $\begin{array}{l}\text { MII } \\
\text { MLLW }\end{array}$ & $\begin{array}{l}\text { Maintenance Investment Index } \\
\text { mixed low-level waste }\end{array}$ \\
\hline HVAC & $\begin{array}{l}\text { heating, ventilation, and air } \\
\text { conditioning }\end{array}$ & MOOSE & $\begin{array}{l}\text { Multiphysics Object Oriented } \\
\text { Simulations Environment }\end{array}$ \\
\hline $\mathrm{IAB}$ & INL Administration Building & N\&HS & National and Homeland \\
\hline IAEA & International Atomic Energy & & Security \\
\hline ICDF & $\begin{array}{l}\text { Agency } \\
\text { Idaho CERCLA Disposal }\end{array}$ & NASA & $\begin{array}{l}\text { National Aeronautics and Space } \\
\text { Administration }\end{array}$ \\
\hline & Facility & NDA & Non-destructive Assay \\
\hline ICIS & $\begin{array}{l}\text { Instrumentation Control and } \\
\text { Intelligent System }\end{array}$ & NEPA & $\begin{array}{l}\text { National Environmental Policy } \\
\text { Act }\end{array}$ \\
\hline ICP & Idaho Cleanup Project & NNSA & National Nuclear Security \\
\hline ICS & Integrated Control System & & Administration \\
\hline IFM & Idaho Facilities Management & NPG & Naval Proving Ground \\
\hline IGPP & Institutional General Plant & NR & Naval Reactors \\
\hline & Project & NRAD & Neutron Radiography Reactor \\
\hline IM & information management & NRC & Nuclear Regulatory \\
\hline IMCL & $\begin{array}{l}\text { Irradiated Materials } \\
\text { Characterization Laboratory }\end{array}$ & NRE & $\begin{array}{l}\text { Commission } \\
\text { National Register Eligible }\end{array}$ \\
\hline INL & Idaho National Laboratory & $\mathrm{NRF}$ & Naval Reactors Facility \\
\hline INTEC & $\begin{array}{l}\text { Idaho Nuclear Technology and } \\
\text { Engineering Center }\end{array}$ & $\begin{array}{l}\text { NSUF } \\
\text { O\&M }\end{array}$ & $\begin{array}{l}\text { National Scientific User Facility } \\
\text { operation and maintenance }\end{array}$ \\
\hline IORC & $\begin{array}{l}\text { Information Operations and } \\
\text { Research Center }\end{array}$ & $\begin{array}{l}\text { OOS } \\
\text { OSF }\end{array}$ & $\begin{array}{l}\text { out of service } \\
\text { other structures and facilities }\end{array}$ \\
\hline $\begin{array}{l}\text { IRC } \\
\text { ISFSI }\end{array}$ & $\begin{array}{l}\text { INL Research Center } \\
\text { Independent Spent Fuel Storage }\end{array}$ & & $\begin{array}{l}\text { (one of four FIMS categories of } \\
\text { real property) }\end{array}$ \\
\hline ITG & $\begin{array}{l}\text { Installation } \\
\text { Idaho Treatment Group, LLC }\end{array}$ & PAR & $\begin{array}{l}\text { programmable and remote } \\
\text { (manipulator) }\end{array}$ \\
\hline IWTU & $\begin{array}{l}\text { Integrated Waste Treatment } \\
\text { Unit }\end{array}$ & PCM & $\begin{array}{l}\text { personnel contamination } \\
\text { monitor }\end{array}$ \\
\hline LCB & Life-Cycle Baseline & PIE & postirradiation examination \\
\hline LED & light-emitting diode & PINS & portable isotopic neutron \\
\hline LEED & Leadership in Energy and & & spectroscopy \\
\hline & Environmental Design & PSO & Program Secretarial Office \\
\hline LEU & low-enriched uranium & $\mathrm{R} \& \mathrm{D}$ & research and development \\
\hline LLW & low-level waste & RAL & Remote Analytical Laboratory \\
\hline LNG & liquefied natural gas & RAM & radiation air monitor \\
\hline LP & Laboratory Protection & RAMP & Roof Asset Management \\
\hline LWR & light water reactor & & Program \\
\hline $\mathrm{MaCS}$ & Microscopy and & RCL & Radiochemistry Laboratory \\
\hline $\mathrm{MC}$ & $\begin{array}{l}\text { Characterization Suite } \\
\text { mission-critical (one of three }\end{array}$ & RCRA & $\begin{array}{l}\text { Resource Conservation and } \\
\text { Recovery Act }\end{array}$ \\
\hline & $\begin{array}{l}\text { FIMS Mission Dependency } \\
\text { categories) }\end{array}$ & RD\&D & $\begin{array}{l}\text { research, development, and } \\
\text { demonstration }\end{array}$ \\
\hline MD & $\begin{array}{l}\text { mission-dependent, not critical } \\
\text { (one of three FIMS Mission }\end{array}$ & REC & $\begin{array}{l}\text { Research and Education } \\
\text { Campus }\end{array}$ \\
\hline & Dependency categories) & REL & Research Education Laboratory \\
\hline
\end{tabular}




\begin{tabular}{|c|c|c|c|}
\hline RERTR & Reduced Enrichment for & TEC & total estimated cost \\
\hline & Research and Test Reactor & TEM & transmission electron \\
\hline RESL & Radiological and Environmental & & microscope \\
\hline & Science Laboratory & TLD & thermoluminescent dosimeter \\
\hline ROM & rough order of magnitude & TMI & Three-Mile Island \\
\hline RPV & replacement plant value & ТPC & total project cost \\
\hline RTR & Real Time Radiography & TRA & Test Reactor Area (legacy \\
\hline RWMC & Radioactive Waste Management & & building number prefix) \\
\hline S\&S & $\begin{array}{l}\text { Complex } \\
\text { safeguards and security }\end{array}$ & TREAT & $\begin{array}{l}\text { Transient Reactor Experiment } \\
\text { and Test Facility }\end{array}$ \\
\hline SBW & sodium bearing waste & TRIGA & Training, Research, Isotopes, \\
\hline SCADA & Supervisory Control and Data & & General Atomics \\
\hline & Acquisition & TRU & transuranic \\
\hline SDA & Subsurface Disposal Facility & TSA & Transuranic Storage Area \\
\hline SEM & scanning electron microscope & TSB & Technical Support Building \\
\hline SMC & Specific Manufacturing & TSCA & Toxic Substances Control Act \\
\hline & Capability & TTAF & Test-Train Assembly Facility \\
\hline SNM & special nuclear material & TYSP & Ten-Year Site Plan \\
\hline SPO & Sustainability Performance & UESC & Utility Energy Savings Contract \\
\hline & Office & UNF & used nuclear fuel \\
\hline SSP & Site Sustainability Plan & UREP & Utilities Replacement \\
\hline SSPP & Strategic Sustainability & & Enhancement Project \\
\hline & Performance Plan & VFD & variable frequency drive \\
\hline SSPSF & Space and Security Power & WAG & Waste Area Group \\
\hline & Systems Facility & WCB & Willow Creek Building \\
\hline SSSTF & Staging, Storing, Sizing, and & WIPP & Waste Isolation Pilot Plant \\
\hline & Treatment Facility & WMD & weapons of mass destruction \\
\hline SW & sitewide & ZPPR & Zero Power Physics Reactor \\
\hline
\end{tabular}




\section{INTRODUCTION}

This Idaho National Laboratory (INL) Ten-Year Site Plan (TYSP) describes the approach for managing real property assets to meet the Department of Energy Office of Nuclear Energy (DOE-NE) mission: to promote nuclear power as a resource capable of making major contributions in meeting the nation's energy supply, environmental, and energy security needs.

As the DOE-NE national nuclear laboratory, INL serves a unique role in civilian nuclear energy research. With a 60 -year history in reactor and fuel-cycle technology research, development, and demonstration (RD\&D), and as steward to the majority of the Department of Energy (DOE) infrastructure for nuclear energy development, INL assists DOE-NE by leading, coordinating, and participating in RD\&D performed by national laboratories, U.S. universities, and collaborating international research institutions.

INL is also a multiprogram laboratory. Many of these competencies developed from expertise or infrastructure initially developed for its nuclear energy mission. Besides nuclear energy, INL missions encompass National and Homeland Security (N\&HS), energy development, and environmental stewardship. The customer base is broad, supporting missions of DOE, other federal agencies, universities, and industry where INL has distinctive competencies. INL also serves a unique role in the Intermountain West Region as a technical resource and "honest broker" on local and regional issues related to the future direction of energy production and distribution.

Other federal agencies supported by INL include the National Aeronautics and Space Administration (NASA), Department of Defense (DOD), Department of Homeland Security (DHS), Nuclear Regulatory Commission (NRC), and Department of Interior. Some of this work involves application of INL's nuclear energy capabilities (e.g., nuclear forensics, nuclear nonproliferation, and radioisotope power systems assembly and testing), while other work is an extension of its capabilities and expertise in analysis, testing, validation, and demonstration in areas such as critical infrastructure protection, clean-energy system testing, energy storage, and related enabling technologies.

a. Managing and Operating Contract No. DE-AC07-05ID14517 with Battelle Energy Alliance, LLC (BEA).

\section{INL Mission}

Advance nuclear power as a resource

capable of making major contributions

in meeting the nation's energy supply,

environmental, and energy security

needs. Serve as a multiprogram

laboratory with competencies that

extend beyond nuclear energy to other

energy, environmental, and N\&HS

challenges. ${ }^{a}$

\section{DOE Vision for INL}

- Enhance the nation's energy security needs [Don't add "needs" - INL is enhancing the security, not enhancing the needs] by becoming the preeminent, internationally recognized nuclear energy $R D \& D$ laboratory.

- Establish itself as a major center for national security technology development and demonstration.

- Be a multiprogram national laboratory with world-class capabilities.

- Foster academic, industry, government, and international collaborations to produce the 
INL works closely with the nuclear industry on DOE research initiatives to bring an industry perspective to research and development (R\&D) efforts, and to meet its specific needs. INL supports engineering and applied research by industry partners in other segments of the energy sector as well as automobile manufacturing, agribusiness, and other industries.

The TYSP builds on information provided in the Nuclear Energy Research and Development Roadmap (DOE 2010; DOE-NE Roadmap), annual DOE-NE program guidance, and reports such as the "Facilities for the Future of Nuclear Energy Research: A Twenty-Year Outlook" (DOE-NE 2009). In addition, the TYSP incorporates the 2008 recommendations of the National Academy of Sciences (NAS 2008), which recognized the need for DOE-NE to invest in research capabilities and develop a process for prioritizing, evaluating, and obtaining them.

The TYSP serves as the real property asset plan for INL. Though budget formulation documents are informed by the TYSP, it is not itself a budget document.

\subsection{Nuclear Energy Mission}

INL's primary mission is to advance nuclear energy by supporting DOE-NE in achieving its objectives. In the 2010 DOE-NE Roadmap (DOE 2010), DOE-NE identified four research objectives it is pursuing to accomplish its mission of advancing nuclear energy:

- Objective 1 - Develop technologies and other solutions that can improve reliability, sustain safety, and extend the life of current reactors. INL provides overall technical leadership to the advanced Light Water Reactor (LWR) Sustainability Program; leads research pathways for advanced LWR nuclear fuels (including fuel performance modeling), advanced instrumentation and control systems, and risk-informed safety margin characterization; and is a participant on all the research pathways.

- Objective 2 - Develop improvements in the affordability of new reactors to enable nuclear energy to help meet the Administration's energy security and climate change goals. INL performs fuel performance modeling, supporting advanced modeling applications for new and advanced reactor and fuel-cycle technologies. INL leads the development and qualification of fuel and graphite for an advanced high-temperature gas reactor, and interacts with NRC on developing a licensing framework for the Next Generation Nuclear Plant.

- Objective 3 - Manage nuclear waste and develop sustainable nuclear fuel cycles. INL provides technical leadership to several focus areas, including fuel development, separations and waste form development, and systems analysis.

- Objective 4 - Understand and minimize the risks of nuclear proliferation and terrorism. INL fuel-cycle facilities (e.g., the Fuel Conditioning Facility [FCF]) will support development of approaches and testing of process control instrumentation and new sampling systems that provide near real-time accountability.

\subsection{National Nuclear Capability}

The DOE-NE Roadmap (DOE 2010) calls for increased coupling of theory with fundamental phenomenological testing, and modeling and simulation to accomplish DOE research objectives. This approach does not obviate the need for future larger-scale testing; however, it enables exploration of various technology options before having to prepare and invest in larger-scale testing. DOE-NE requires 
access to many capabilities - from small-scale laboratory experiments to larger-scale prototypic demonstrations - to explore new technologies. This section describes INL's capabilities to support the full spectrum of DOE-NE needs.

INL maintains and operates the majority of DOE-NE's essential nuclear energy R\&D capabilities, which represent the core of the federal government's national nuclear energy R\&D infrastructure. Core capabilities are those that: (1) are unique to nuclear energy R\&D, (2) typically enable handling of highly radioactive materials, or (3) are expensive to build/operate. Test reactors, hot cells, and shielded enclosures are at the top of the hierarchy of facilities in degree of complexity, making it possible to handle highly radioactive materials, followed by smaller-scale radiological facilities, specialty engineering facilities, and nonradiological laboratories.

As one of the few laboratories that can handle Safeguards Category I materials, INL has the unique ability to support research using fissile and highly radioactive fuels and materials. Under the Settlement Agreement between the State of Idaho, DOE, and U.S. Navy (State of Idaho 1995), INL can receive research quantities of used nuclear fuel (UNF). This enables INL to support research associated with existing and advanced reactor and fuel-cycle technologies, and to support the needs of industry and DOE in developing and qualifying new fuels, including fuels with enhanced accident tolerance.

Core capabilities operated by INL that are unique to nuclear energy R\&D include:

- Neutron irradiation in the Advanced Test Reactor (ATR) and Advanced Test Reactor Critical (ATRC) Facility and neutron radiography and small test component irradiation in the Neutron Radiography Reactor (NRAD).

- Postirradiation examination (PIE), testing, and characterization in the Hot Fuel Examination Facility (HFEF), Analytical Laboratory (AL), Electron Microscopy Laboratory (EML), Fuels and Applied Science Building (FASB), Center for Advanced Energy Studies (CAES), and Irradiated Materials Characterization Laboratory (IMCL).

- Experimental fuel development (fabrication process development) in the Fuel Manufacturing Facility (FMF), FCF, Experimental Fuels Facility (EFF), HFEF, and FASB.

- Separations and waste form development in the Radiochemistry Laboratory (RCL), Central Facilities Area (CFA), Bonneville County Technology Center (BCTC), FASB, and FCF/HFEF.

- Advanced nuclear and nonnuclear analysis/modeling and simulation via high-performance computing in the High-Performance Computing Center featuring the Multiphysics Object Oriented Simulations Environment (MOOSE) platform, along with nuclear applications that predict the behavior of fuels and materials under operating and accident conditions and visualization tools such as the Computer Assisted Virtual Environment in CAES.

- Other specialized testing capabilities (e.g., nuclear facilities, hot cells, and shielded enclosures dedicated to radioisotope power-source assembly [the Space and Security Power Systems Facility \{SSPSF\}], thermal hydraulic testing and instrumentation, human factors and digital instrumentation and control, and those associated with testing UNF in storage configurations and conducting tests in highly radioactive environments).

To support the DOE-NE mission, INL opens its facilities to other laboratories and universities participating in DOE research, as well as to the broader nuclear energy research community. Specialized capabilities in reactor technologies, fuel-cycle development, and systems engineering that qualify INL to 
conduct nuclear energy R\&D are also available to help other federal agencies, industry, and regional partners meet their mission needs. INL offers a remote location with the safeguards, security, and safety infrastructure to manage radiological and nuclear materials and testing under normal and abnormal conditions.

While national laboratories do not compete with industry, they retain unique capabilities that are generally complex and expensive to maintain and operate. Research conducted by other agencies and industry that requires access to DOE national laboratories is generally of national importance and involves cost-shared cooperation between DOE and an agency or DOE and industry (e.g., the radioisotope power system and the LWR sustainability programs). INL also provides direct contracted technical support to industry. In this instance, the research often takes place under a Cooperative Research and Development Agreement (CRADA), and the research results are often proprietary to the customer.

Table 1-1 summarizes INL core capabilities and facilities that are operational, in progress, or planned; the DOE-NE Roadmap objectives that require them; and current or other potential customers. Section 4 is a general discussion of other support facilities and structures required to sustain these key R\&D facilities (e.g., steam plants, electrical distribution systems, and waste and material storage facilities).

Table 1-1. Idaho National Laboratory nuclear energy research and development core physical research capabilities - operational, in progress, or planned.

\begin{tabular}{|c|c|c|c|c|c|c|c|c|c|c|}
\hline \multirow[b]{2}{*}{ Core Capabilities/Functionality } & \multirow[b]{2}{*}{ INL Facilities ${ }^{a}$} & \multicolumn{4}{|c|}{$\begin{array}{c}\text { DOE-NE Objectives } \\
(1-4)\end{array}$} & \multicolumn{5}{|c|}{ Other Users ${ }^{b}$} \\
\hline & & 1 & 2 & 3 & 4 & NNSA & Univ. & $\begin{array}{l}\text { Other } \\
\text { Fed. }\end{array}$ & $\begin{array}{l}\text { Intl. } \\
\text { Coop }\end{array}$ & Industry \\
\hline \multicolumn{11}{|l|}{ Irradiation/Capabilities } \\
\hline Thermal-spectrum irradiation & $\begin{array}{l}\text { ATR/ATRC/ } \\
\text { NRAD (small test } \\
\text { components) }\end{array}$ & $\bullet$ & $\bullet$ & $\bullet$ & $\bullet$ & $\bullet$ & $\bullet$ & $\bullet$ & $\bullet$ & $\bullet$ \\
\hline Transient irradiation & $\begin{array}{l}\text { Transient } \\
\text { Reactor } \\
\text { Experiment and } \\
\text { Test Facility } \\
\text { (TREAT) } \\
\text { (cold standby) }\end{array}$ & $\bullet$ & $\bullet$ & & $\bullet$ & $\bullet$ & $\bullet$ & $\bullet$ & $\bullet$ & $\bullet$ \\
\hline Neutron Radiography & NRAD & $\bullet$ & $\bullet$ & $\bullet$ & $\bullet$ & $\bullet$ & $\bullet$ & $\bullet$ & $\bullet$ & $\bullet$ \\
\hline \multicolumn{11}{|c|}{ PIE and Fresh Fuel Characterization Capabilities } \\
\hline Receipt of irradiated fuels/materials & HFEF & $\bullet$ & $\bullet$ & $\bullet$ & $\bullet$ & $\bullet$ & • & $\bullet$ & $\bullet$ & $\bullet$ \\
\hline $\begin{array}{l}\text { Nondestructive examinations } \\
\text { (physical dimensions, photography, } \\
\text { gamma scanning, neutron } \\
\text { radiography, eddy current } \\
\text { evaluation, etc.) }\end{array}$ & HFEF & • & $\bullet$ & $\bullet$ & $\bullet$ & $\bullet$ & • & • & $\bullet$ & • \\
\hline $\begin{array}{l}\text { Destructive initial analysis (pin } \\
\text { puncturing, gas pressure, fission } \\
\text { gas sampling and analysis, and } \\
\text { void volume) }\end{array}$ & HFEF & • & • & $\bullet$ & & $\bullet$ & • & • & • & $\bullet$ \\
\hline
\end{tabular}


Table 1-1. (continued).

\begin{tabular}{|c|c|c|c|c|c|c|c|c|c|c|}
\hline \multirow[b]{2}{*}{ Core Capabilities/Functionality } & \multirow[b]{2}{*}{ INL Facilities $^{\mathrm{a}}$} & \multicolumn{4}{|c|}{$\begin{array}{l}\text { DOE-NE Objectives } \\
(1-4)\end{array}$} & \multicolumn{5}{|c|}{ Other Users ${ }^{b}$} \\
\hline & & 1 & 2 & 3 & 4 & NNSA & Univ. & $\begin{array}{l}\text { Other } \\
\text { Fed. }\end{array}$ & $\begin{array}{l}\text { Intl. } \\
\text { Coop }\end{array}$ & Industry \\
\hline $\begin{array}{l}\text { Destructive examinations (cutting/ } \\
\text { sectioning, sample mounting, } \\
\text { grinding/polishing/etching, and } \\
\text { optical microscopy) }\end{array}$ & HFEF & $\bullet$ & $\bullet$ & $\bullet$ & & $\bullet$ & $\bullet$ & $\bullet$ & • & $\bullet$ \\
\hline $\begin{array}{l}\text { Mechanical testing of highly } \\
\text { radioactive materials (sample } \\
\text { preparation/machining/punching; } \\
\text { high temperature mechanical } \\
\text { properties; fatigue and crack } \\
\text { growth; tensile, hardness, impact } \\
\text { testing, etc.) }\end{array}$ & HFEF/FASB & $\bullet$ & $\bullet$ & $\bullet$ & $\bullet$ & $\bullet$ & $\bullet$ & $\bullet$ & $\bullet$ & $\bullet$ \\
\hline $\begin{array}{l}\text { Destructive analyses (chemical and } \\
\text { isotopic analysis, material } \\
\text { characterization, fuel density, } \\
\text { fission gas retention, crack-growth } \\
\text { rate, electro-optical examination, } \\
\text { including scanning electron } \\
\text { microscope [SEM], transmission } \\
\text { electron microscope [TEM], focused } \\
\text { ion beam [FIB], etc.) }\end{array}$ & $\begin{array}{l}\text { HFEF/AL/EML/F } \\
\text { ASB/CAES/INL } \\
\text { Research Center } \\
\text { (IRC)/IMCL }\end{array}$ & $\bullet$ & $\bullet$ & $\bullet$ & & $\bullet$ & $\bullet$ & $\bullet$ & $\bullet$ & $\bullet$ \\
\hline \multicolumn{11}{|c|}{ Experimental Fuel Fabrication Capabilities (Glovebox lines collocated with irradiation facilities) } \\
\hline $\begin{array}{l}\text { Fuel containing plutonium and } \\
\text { minor actinides that can be contact } \\
\text { handled (ceramic, metal); small } \\
\text { rods and targets up to dose limits }\end{array}$ & $\begin{array}{l}\text { FMF/Zero Power } \\
\text { Physics Reactor } \\
\text { (ZPPR) }\end{array}$ & $\bullet$ & $\bullet$ & $\bullet$ & $\bullet$ & $\begin{array}{l}\text { Material } \\
\text { Storage }^{c}\end{array}$ & $\bullet$ & $\bullet$ & $\bullet$ & $\bullet$ \\
\hline $\begin{array}{l}\text { Fuel that must be fabricated in a } \\
\text { shielded facility, pin/rod scale }\end{array}$ & FCF/HFEF & $\bullet$ & & $\bullet$ & & & • & • & $\bullet$ & $\bullet$ \\
\hline $\begin{array}{l}\text { Highly enriched uranium (HEU), } \\
\text { low-enriched uranium (LEU), } \\
\text { thorium in small quantities } \\
\text { (pin/plate), and characterization } \\
\text { (irradiation-assisted stress } \\
\text { corrosion cracking capability) }\end{array}$ & FASB & $\bullet$ & & $\bullet$ & & $\bullet$ & $\bullet$ & $\bullet$ & $\bullet$ & $\bullet$ \\
\hline $\begin{array}{l}\text { LEU in larger quantities; larger } \\
\text { scale fabrication equipment such as } \\
\text { extrusion presses and rolling mills }\end{array}$ & EFF & $\bullet$ & & $\bullet$ & & $\bullet$ & $\bullet$ & $\bullet$ & $\bullet$ & $\bullet$ \\
\hline \multicolumn{11}{|c|}{ Advanced Separations and Waste Forms (Hot cells and RCLs) } \\
\hline $\begin{array}{l}\text { Aqueous separations and } \\
\text { pretreatment technologies }\end{array}$ & $\begin{array}{l}\text { RCL, FASB, } \\
\text { CFA, BCTC }\end{array}$ & & & • & $\bullet$ & $\bullet$ & $\bullet$ & & $\bullet$ & \\
\hline $\begin{array}{l}\text { Electrochemical separations and } \\
\text { waste form (engineering scale) }\end{array}$ & FCF/HFEF & & & • & $\bullet$ & • & • & & $\bullet$ & \\
\hline
\end{tabular}


Table 1-1. (continued).

\begin{tabular}{|c|c|c|c|c|c|c|c|c|c|c|}
\hline \multirow[b]{2}{*}{ Core Capabilities/Functionality } & \multirow[b]{2}{*}{ INL Facilitiesa } & \multicolumn{4}{|c|}{$\begin{array}{l}\text { DOE-NE Objectives } \\
(1-4)\end{array}$} & \multicolumn{5}{|c|}{ Other Users ${ }^{b}$} \\
\hline & & 1 & 2 & 3 & 4 & NNSA & Univ. & $\begin{array}{l}\text { Other } \\
\text { Fed. }\end{array}$ & $\begin{array}{l}\text { Intl. } \\
\text { Coop }\end{array}$ & Industry \\
\hline \multicolumn{11}{|l|}{ Specialized Laboratory Facilities } \\
\hline $\begin{array}{l}\text { Radioisotope power system } \\
\text { assembly and test }\end{array}$ & SSPSF & & & & & & & - & & \\
\hline $\begin{array}{l}\text { Modeling and simulation, high } \\
\text { performance computing, and } \\
\text { visualization }\end{array}$ & $\begin{array}{l}\text { CAES / } \\
\text { Engineering } \\
\text { Research Office } \\
\text { Building (EROB) }\end{array}$ & $\bullet$ & - & - & & & • & • & 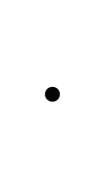 & - \\
\hline $\begin{array}{l}\text { a. Facilities are operational and DOE-NE-owl } \\
\text { b. Capabilities related to fuel fabrication, irrac } \\
\text { c. The Reduced Enrichment for Research an }\end{array}$ & $\begin{array}{l}\text { unless otherwise id } \\
\text { n, fresh fuel charac } \\
\text { st Reactor (RERTR }\end{array}$ & & & & & suppo & stry use & & & \\
\hline
\end{tabular}

\subsection{National and Homeland Security Missions and Capabilities}

By virtue of distinct geography and location, N\&HS unique capabilities, facilities, and expertise complement the nuclear mission of INL. The N\&HS mission focuses on four areas:

1. Protecting U.S. critical infrastructure. The critical infrastructure protection mission focuses on reducing cyber, wireless, and physical security risks across the nation's 16 critical infrastructure sectors (NIPP 2009). INL has unique integrated capabilities in industrial control-systems cyber security; wireless communications; electric power infrastructure emulation, simulation, and modeling; and explosives technologies. Included are assessment of vulnerabilities from physical and cyber attacks, natural disasters, and aging infrastructure, as well as research, development, testing, evaluation, and implementation of protective solutions that address prevention, intrusion detection, system resiliency, and event recovery.

2. Advancing nonproliferation technologies. Nuclear nonproliferation safeguards and security (S\&S) assets support multiple U.S. Government organizations, including DOE-NE and NNSA, with direct relevance to DOE-NE Roadmap Research Objective 4 (Understand and Minimize Proliferation Risk). INL capabilities support, or can support, R\&D in a number of nonproliferation areas, such as fuels that reduce proliferation risk, safeguard approaches and technologies using INL fuel-cycle facilities and expertise, risk management approaches to security, and signatures and observables of proliferation activities.

3. Providing prevention, detection, mitigation, and response-readiness technologies to defeat chemical/radiological/nuclear/explosive threats. In support of the Global Threat Reduction Initiative, INL provides nuclear forensics capability, first responder training, and customer support. Capabilities for fuel fabrication and postirradiation at the Materials and Fuels Complex (MFC) and irradiation in ATR are central to the success of this initiative. INL has capabilities in the detection of, and response to, threats involving chemical, nuclear, and radiological materials, and explosives that are accessed by DOD, DHS, and NNSA for many facets of defense against weapons of mass destruction (WMD). 
4. Manufacturing armor packages for the U.S. Army and supplying R\&D and manufacturing capabilities for other national security needs. The Specific Manufacturing Capability (SMC) plays a key role in supporting national security by providing the capabilities to manufacture armor packages for the U.S. Army Abrams main battle tank. The INL National Security Test Range enables materials and systems tests of both classified and unclassified designs that are important to accomplishing various SMC missions.

\subsection{Energy and Environment Mission and Capabilities}

INL applies science and engineering to expand energy supply, improve energy efficiency, and address the environmental consequences of energy production and use. Specific areas of emphasis include:

- Energy Systems Development and Testing. Supporting DOE, DOD, and industry in addressing challenges in renewable energy supply by providing engineering design and assessment, and prototype development and testing. The focus is on biofuel feedstock production and biopower applications, and geothermal, novel wind, and hybrid energy systems. INL also assists in solving challenges with integrating energy technologies on the grid, including grid stability, load balance, and energy conversion optimization.

- Energy Storage and Advanced Vehicle Testing. Providing benchmark data for technology modeling, simulations, and R\&D in energy storage and advanced vehicle testing, field performance, and life testing of advanced vehicles and batteries. INL also coordinates plug-in demonstration projects with private companies and city, country, port, and environmental entities.

- Advanced Manufacturing and Materials. Including process design, chemical separations, and advanced controls that enable process development and improve material performance. INL performs materials research, providing insight to material performance in harsh environments indicative of fossil and nuclear energy conversion systems and chemical plants. INL also supports development of intelligent systems and controls methods used in a variety of industrial processes and energy conversion industries.

- Assessing the environmental consequences of energy operations. In the field of critical materials recycle and reuse, INL is a partner with Ames National Laboratory and its Critical Materials Institute. INL provides nuclear-chemical separations expertise to develop and test new processing methods that selectively recover critical metals.

INL's energy and environmental mission activities take place in the newly commissioned Energy Systems Laboratory (ESL), IRC, and other facilities within the Research and Education Campus (REC). The ESL houses battery testing, biofuels research, and critical materials research instruments, tools, and equipment.

\subsection{Idaho Cleanup Project}

The Idaho Cleanup Project (ICP) ensures the safe, informed, and judicious use of the INL site by multiple generations following remediation through decisions and actions that: (1) protect human health and the environment from residual contamination; (2) conserve ecological and cultural resources; and (3) respond to regulatory, political, and technological changes.

ICP involves the safe environmental cleanup of the INL site, which was contaminated by conventional weapons testing, government-owned research and defense reactors, laboratory research, and defense missions at other DOE sites. 
The 3-year ICP extension contract is a \$741-million cleanup project, funded through the DOE Office of Environmental Management (DOE-EM). The project, managed and operated by CH2M-WG Idaho (CWI), focuses on: (1) reducing risks to workers, the public, and the environment, and (2) protecting the Snake River Plain Aquifer, the sole drinking water source for more than 300,000 residents of eastern Idaho. Appendix $\mathrm{C}$ discusses this activity in detail.

\subsection{Advanced Mixed Waste Treatment Project}

The Advanced Mixed Waste Treatment Project (AMWTP) mission is to retrieve, characterize, treat, and ship from Idaho legacy transuranic (TRU) and mixed low-level waste (MLLW) stored at the Radioactive Waste Management Complex (RWMC) Transuranic Storage Area (TSA). AMWTP is a DOE-EM-funded project managed and operated by Idaho Treatment Group, LLC (ITG).

Beginning in 1970, approximately 65,000 cubic meters of waste in 55-gallon drums, boxes, and bins were placed on asphalt pads for interim storage at the RWMC TSA. DOE and ITG are working to meet the requirements of the Idaho Settlement Agreement, which states that these wastes must be removed from Idaho by December 31, 2018 (State of Idaho 1995). To date, approximately $90 \%$ of waste has been retrieved from long-term storage and approximately $60 \%$ has been shipped from Idaho. ITG and the DOE Idaho Operations Office (DOE-ID) are shipping waste at a rate that will meet the mandated completion date before December 2018.

The 4-year, \$448 million project also focuses on: (1) reducing risks to workers, the public, and the environment; and (2) protecting the Snake River Plain Aquifer, as discussed in Appendix C.

\subsection{Assumptions}

The following planning assumptions apply to this TYSP:

- Out-year budget profiles will remain relatively constant for all major entities at INL (i.e., DOE-NE, DOE-EM, and the Naval Reactors [NR] Office).

- Infrastructure gaps will be analyzed based on mission requirements. As a first principle, DOE-NE and INL will reuse existing infrastructure where feasible.

- The number of uncleared, onsite visitors and collaborative partners will grow, increasing the need for unrestricted access to experimental capabilities in an open campus environment as much as possible within REC (e.g., CAES, ESL, and Research and Education Laboratory [REL]), which may drive security and general infrastructure needs to accommodate increased use.

- Decisions currently within the National Environmental Policy Act (NEPA) process (Pu-238 and Transient Testing) that may impact infrastructure are not addressed in detail.

\subsection{INL User Facilities}

INL views its unique nuclear R\&D capabilities and infrastructure as national assets available to universities, industry, national laboratories, international research organizations, and other federal agencies. DOE-NE seeks to involve the foremost experts from across the nuclear energy community in its research, including national and international partners from the government as well as private and education sectors. INL seeks to offer its capabilities and related nuclear science and engineering infrastructure to these experts to advance DOE-NE research goals. 
Through the National Scientific User Facility (NSUF), INL offers irradiation and PIE capabilities to help researchers explore and understand the complex behavior of fuels and materials. In 2007, DOE designated ATR and associated PIE capabilities at MFC as user facilities that provide universities, national laboratories, industry, other federal agencies, and international research institutions with greater access. NSUF also includes educational initiatives aimed at preparing nuclear science and engineering students to conduct nuclear energy research and experimentation. As a program, it also encourages teaming among universities, industry, and national laboratories.

NSUF grants university-led scientific groups access to ATR, ATRC, the sample library, and facilities with PIE equipment for work on major projects. In addition, NSUF allows access to any researcher for small-scale, rapid-turnaround projects and provides competitive pricing for industry groups and other federal agencies.

The research sponsored and funded by NSUF links directly to DOE-NE mission accomplishments, as well as to the Nuclear Energy University Program, administered by CAES. In addition, INL is working through a CRADA with the Electric Power Research Institute (EPRI) to enable industry use of INL facilities. The Institute for Nuclear Energy Science and Technology is developing university partners that can work with industry to use the NSUF capability. The NSUF Program, located within the CAES building, is prototyping the laboratory of the future, serving as a gateway to INL and expanding opportunities for broader access.

The INL wireless test bed was designated a national user facility by DOE in January 2013 to enable improved access for academic and industrial users of distinctive capabilities. The Wireless National User Facility enables government, industry, and academic researchers to address some of the nation's most pressing challenges in wireless communications, spectrum sharing, and communications interoperability. 


\section{FACILITIES AND INFRASTRUCTURE}

The proximity of ATR to INL PIE and characterization capabilities, collocated glovebox lines for experimental fuel development, and collocated separations research facilities provides the foundation for national nuclear energy research at INL. With targeted investments, these facilities, along with other facilities supporting (or capable of supporting) future needs for scale-up testing and demonstrations, should meet the needs of DOE-NE and nuclear energy R\&D for years to come.

Since 2005, INL has revitalized and enhanced its research capabilities, beginning with ATR and continuing with MFC and REC. In addition to significant investment in new instruments, tools, and upgrades to existing capabilities and facilities, a number of new research facilities were commissioned. This period of growth, represented by new facilities, is largely complete. INL is directing its resources on sustaining, fully utilizing, and obtaining the most value out of existing real property assets. In addition, the user-facility model established for irradiation, PIE, and the wireless test bed will help assure the full use or access to distinctive research capabilities.

\subsection{Land and Space Planning}

INL land and space planning is a critical element in transforming INL to meet DOE national nuclear $\mathrm{R} \& \mathrm{D}$ goals. The major objective for land and space utilization is to consolidate and collocate like activities and forecast future mission needs. The guiding principles for campus planning are to provide: (1) a collaborative environment to foster scientific innovation, (2) flexible and modern facilities that are reconfigurable to meet changing research needs, (3) environmentally and operationally sustainable facilities, and (4) compliance with federal land use requirements. Near-term plans include full utilization of ESL and REL, terminating two non-enduring leases, repurposing the IRC laboratories and offices, and consolidating and collocating personnel.

\subsection{Idaho National Laboratory Campuses}

Activities associated with nuclear energy security and other energy security missions take place at several locations at INL. Nuclear energy R\&D capabilities are consolidated around three main campuses: REC, the ATR Complex, and MFC (Figure 2-1).

Each campus supports specific missions based on capabilities and functions. For instance, the ATR Complex is the primary location to conduct thermal irradiation; MFC provides shielded hot cells for handling highly irradiated materials and gloveboxes for handling special nuclear material (SNM); and REC provides nonradiological laboratories and administrative facilities that support multiple laboratory missions. In addition, N\&HS has numerous test ranges located throughout the INL site.

\subsubsection{REC}

REC (Figure 2-2), the gateway to INL, includes diverse laboratories supporting all INL research areas. INL is transforming REC to be more conducive to collaboration with business and university partners while providing the latest in laboratory and office efficiencies. INL has repurposed its buildings to enable the consolidation and collocation of activities from outlying and substandard-leased spaces to the main campus area in Idaho Falls. 


\section{9,135 Acres 889 Square Miles}

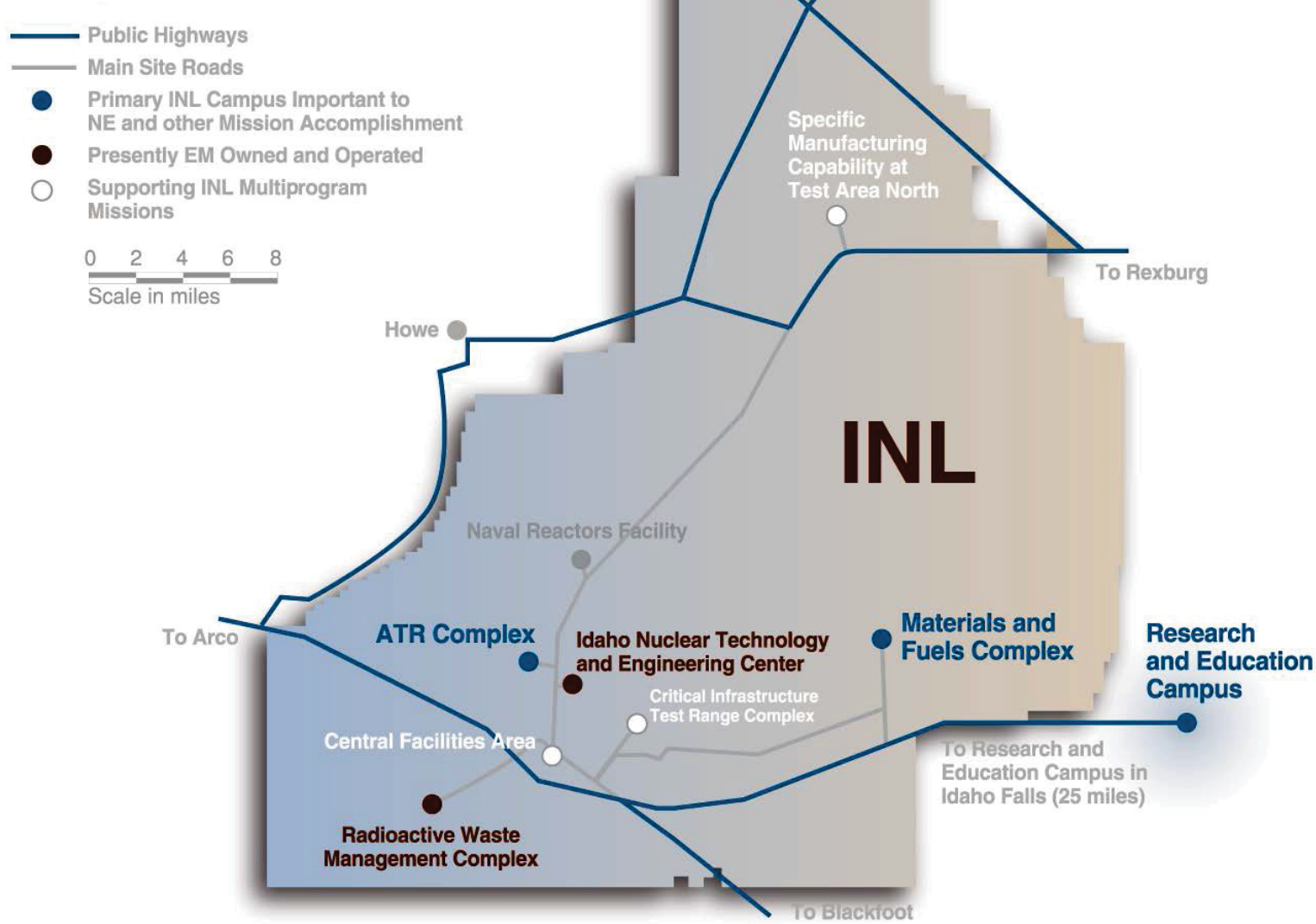

Figure 2-1. Idaho National Laboratory campuses.

REC houses a variety of research capabilities and facilities as well as INL administrative functions. EROB $\left(280,000 \mathrm{ft}^{2}\right)$, a research office building, houses the INL High-Performance Computing (HPC) Data Center $\left(3,700 \mathrm{ft}^{2}\right)$. The data center provides essential support for modeling and simulation work as well as multiple program missions. In 2011, INL installed a supercomputer known as "Fission." INL upgrades its computing capabilities approximately every 3 years.

The ESL, a new 91,000- $\mathrm{ft}^{2}$ laboratory and office facility that began operations in Fiscal Year (FY) 2013, is the largest new research laboratory built at INL in the last 30 years. It houses multiple research programs for advancing energy security and reducing risks that may be associated with new technologies. It expands current capabilities and provides state-of-the-art high-bays and laboratory space for programs formerly housed in IRC and BCTC. ESL enables research and demonstration in bioenergy feedstock processing, advanced battery testing, and hybrid energy systems-integration.

REL (148,000 $\left.\mathrm{ft}^{2}\right)$, currently under construction, will be the R\&D and NSUF showcase for INL, offering state-of-the-art laboratory and office space and a scientific conference center. This facility will consolidate laboratories needed for fundamental R\&D activities and provide opportunities to centralize key research functions at REC. Specifically, this laboratory will support chemical sciences, nanotechnology, water chemistry, advanced microscopy, control systems, high-temperature testing, thermal hydraulics, materials testing and characterization, separations technology, and advanced instrument training. INL will occupy REL in FY 2014. 


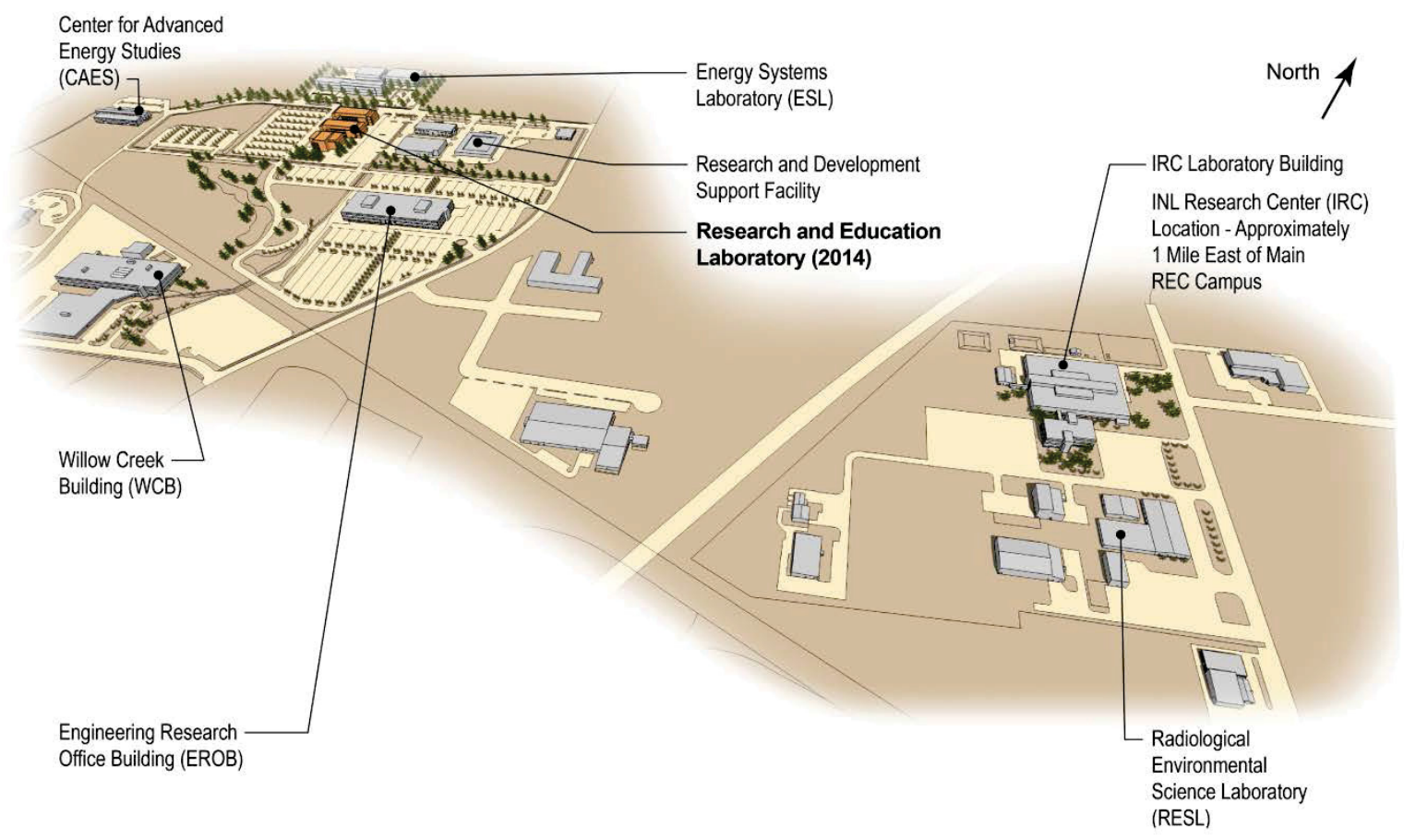

Figure 2-2. Research and Education Campus.

IRC $\left(280,000 \mathrm{ft}^{2}\right)$ is a collection of laboratories that support advanced research, process development, and applied engineering in biology, chemistry, metallurgy, robotics, materials characterization, modeling and computational science, physics, and high-temperature electrolysis production of hydrogen for nuclear and nonnuclear energy applications. Its large footprint, including high-bay areas for small-scale pilot plant research, enables advancement of basic research and bench-scale concepts into viable, integrated systems (e.g., hybrid energy systems). INL will assess options and will develop an integrated plan to repurpose space in IRC to meet nuclear energy, environmental, and energy security multiprogram R\&D needs.

The Radiological and Environmental Science Laboratory (RESL) is a critical resource for DOE and the Office of Health, Safety, and Security. RESL features analytical chemistry and radiation protection, and serves as a reference laboratory for numerous performance evaluation programs. It also provides technical support and quality assurance metrology, which is directly traceable to the National Institute of Standards and Technology. RESL also houses INL's whole body counter.

The CAES $\left(55,000 \mathrm{ft}^{2}\right)$ facility fosters multi-institution, collaborative energy research programs important to the nation, attracts students and faculty to the Idaho state universities, promotes informed energy policy dialogue across Idaho and the nation, and acts as a catalyst for technology-based economic development in Idaho. CAES houses modern materials science laboratories and imaging equipment featuring an Atom Probe. It also features a four-wall computer-assisted immersive virtual environment for advanced visualization and modeling. Other laboratories are dedicated to actinide sciences, analytical chemistry, and carbon management. These capabilities are made available to CAES partners through collaborative research activities in nuclear science and engineering, bioenergy, carbon management, energy efficiency, and advanced materials. 
Three REC facilities dedicated to the INL N\&HS mission house research and program capabilities that require secure locations for cyber security, power grid reliability, and wireless communication RD\&D. Capabilities include the following:

- National Response Center for the Industrial Control Systems Cyber Emergency Response Team

- International Atomic Energy Agency (IAEA) safeguards laboratory

- National Supervisory Control and Data Acquisition (SCADA) test bed for DOE's Office of Electricity Delivery and Energy Reliability

- Ultratrace radioanalytical laboratories

- Rapid prototyping facilities and integrated test systems for Instrumentation Control and Intelligent System (ICIS).

Other REC facilities, including EROB, also support this mission. These facilities provide continuity between modeling and simulation and full-scale testing at the Test Range, supporting a build/test/build approach.

\subsubsection{ATR Complex}

Located 45 miles west of Idaho Falls, ATR is one of the world's most versatile materials test reactors (Figure 2-3). A low-temperature, pressurized, water-cooled reactor for steady-state irradiation, ATR meets the irradiation testing needs of DOE-NE, NR, NNSA, and many other researchers. Other facilities in the complex include the associated ATRC, Test-Train Assembly Facility (TTAF), Radioanalytical Chemistry Laboratory, and Radiation Measurements Laboratory.

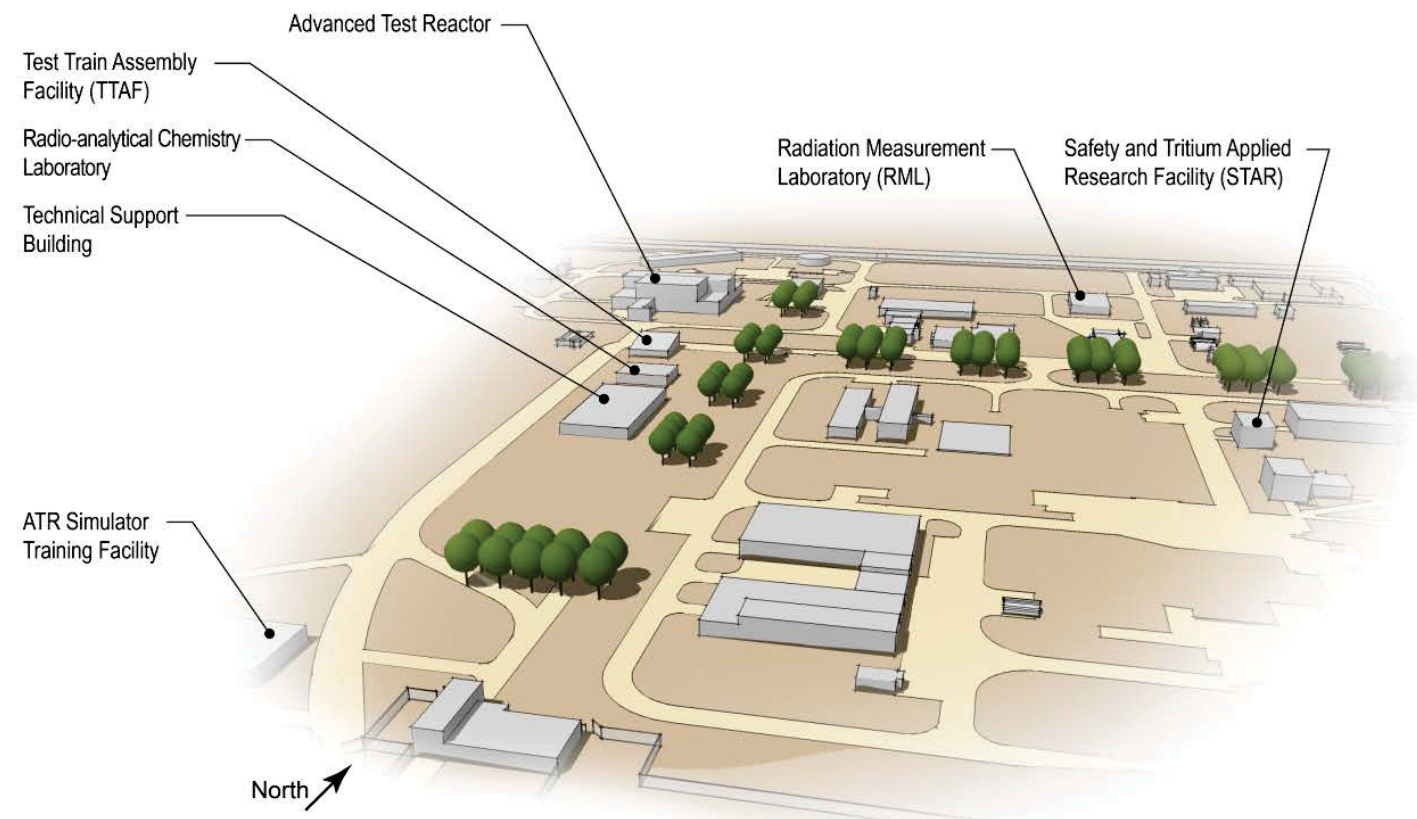

Figure 2-3. Advanced Test Reactor Complex. 
ATR has historically supported fuel development for the Navy's nuclear propulsion program. Over the last decade, its use has expanded into other mission areas that include particle fuel and graphite materials development for the high-temperature gas reactor, minor actinide-bearing fuel development, and low enriched fuel for the NNSA RERTR Program, which is part of the Global Threat Reduction Initiative.

The ATR Life Extension Program is pursuing activities that provide long-term sustainability to ATR while improving its operational reliability. After concluding these specific activities in FY 2015, ATR will continue to implement ongoing maintenance and repair activities and the core internals change-out that occurs approximately every 10 years. The next change-out is planned for 2016.

In FY 2011, in response to the Fukushima nuclear plant accident, DOE allocated funds to accelerate the following defense-in-depth retrofits:

1. Increase heat exchanger support seismic capacity

2. Design and install auxiliary canal fill system

3. Provide station blackout power for one of the ATR emergency cooling pumps.

Many of these upgrades are complete. Other activities associated with emergency response equipment will take place in FY 2013.

Installation of an uninterruptible power supply began in FY 2013, as well as a condition based maintenance program to improve operational reliability. The Preventative Maintenance Optimization phase is underway to evaluate and classify systems and components.

Recent additions to the ATR Complex include a Technical Support Building (TSB; $16,400 \mathrm{ft}^{2}$ ), office space; TTAF $\left(4,483 \mathrm{ft}^{2}\right)$, containing high precision equipment for experiment test-train assembly; the replacement Radiation Measurement Laboratory $\left(6,929 \mathrm{ft}^{2}\right)$; and the Radioanalytical Chemistry Laboratory $\left(4,600 \mathrm{ft}^{2}\right)$.

Besides the planned ATR maintenance, significant investments needed at the ATR Complex include an operational support facility essential to core internal change-out and a modernized instrumentation and control system for the ATRC Facility Control System, a low-pressure reactor that directly supports the ATR test program.

\subsection{MFC}

MFC, located 28 miles west of Idaho Falls, enables fuel fabrication and PIE (Figure 2-4). It is home to the TREAT facility (currently in cold standby); NRAD (a Training, Research, Isotopes, General Atomics [TRIGA] reactor); and hot cell facilities. The hot cell facilities support PIE and advanced separations and waste form research at HFEF, FCF, FASB, and the ZPPR Facility, which has been repurposed for N\&HS testing and evaluation related missions as well as continuing DOE-NE SNM management. The ZPPR reactor shut down in 1992, and the reactor compartment was subsequently removed.

MFC houses analytical laboratories (including mass separators), EML for isotopic and nanometer-scale microstructural and microchemical analysis of material samples from its research facilities, and collocated fuel fabrication glovebox lines (e.g., FMF and FASB). In addition, MFC operates SSPSF for final assembly and testing of radioisotope power systems. 


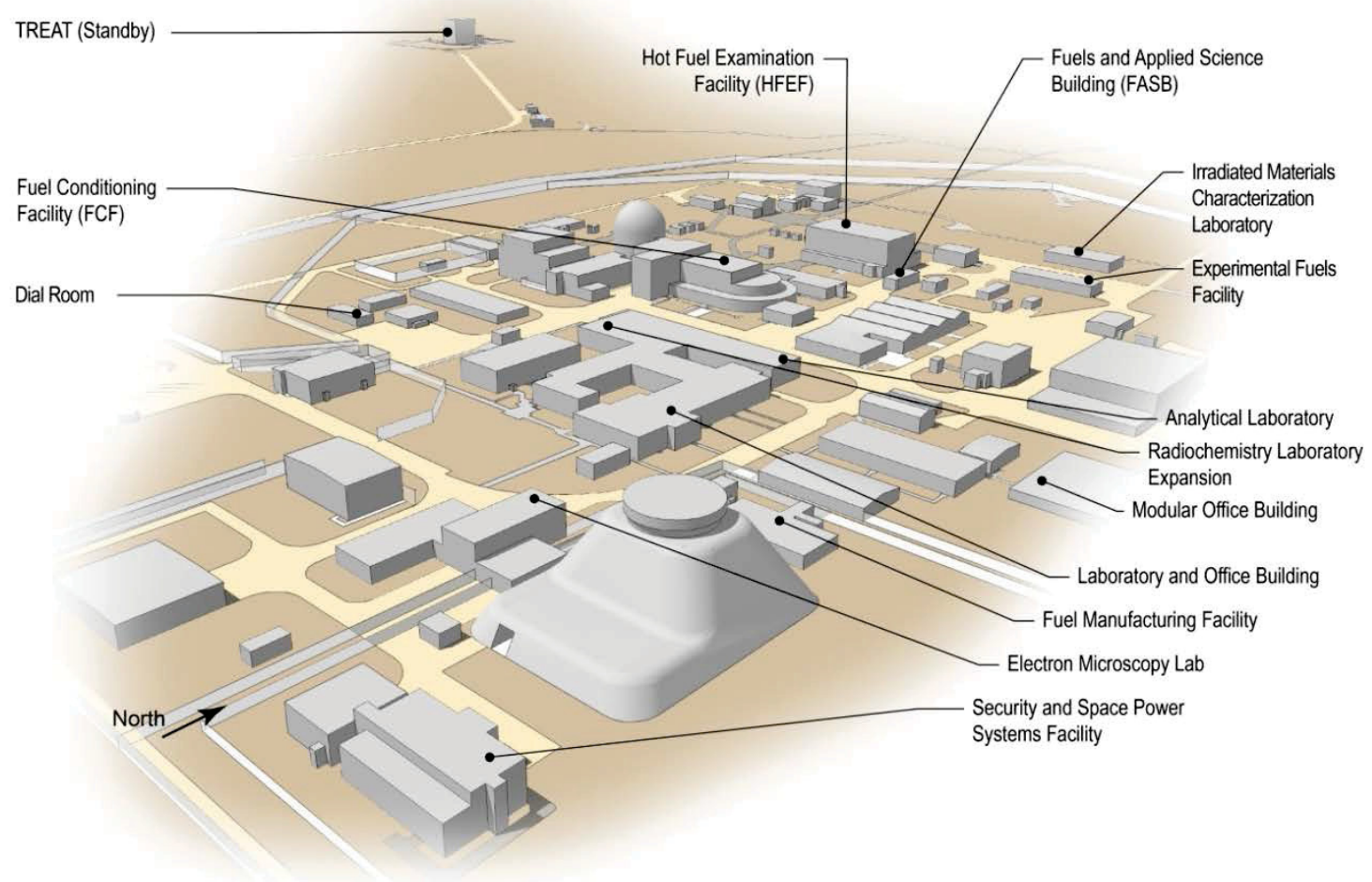

Figure 2-4. Materials and Fuels Complex.

INL completed construction of IMCL $\left(12,000 \mathrm{ft}^{2}\right)$ in FY 2012 and is preparing for fuels and materials characterization R\&D. Designed to perform advanced PIE studies, IMCL will also be available to prototype and demonstrate any future PIE investments. A Hazard Category 2 nuclear facility, it was designed and constructed to be flexible and reconfigurable in order to support a variety of research in irradiated and nonirradiated materials.

Also in FY 2012, INL completed and initiated operations in EFF, which houses research equipment dedicated to fuel fabrication R\&D. EFF capabilities include rolling uranium foil, machining uranium with a computer numeric control lathe, and providing for general uranium handling. It will soon have the capability for electric discharge machining of uranium. By the end of FY 2013, EFF will house a complete ceramic/uranium processing capability, including mixing, grinding, classifying, pressing, and sintering with multiple process line options. Further expansion of the TRU ceramic fuel fabrication capability will proceed based on DOE-NE needs.

SSPSF completed facility upgrades in FY 2012 to provide greater flexibility and surge capacity for fueling multiple units in a short timeframe. SSPSF is the dedicated production facility for assembly and testing operations of radioisotope-powered systems.

INL recently completed multiple MFC utility upgrades, including a new MFC dial room constructed in FY 2012. The associated information technology equipment connections and cutover were completed in FY 2013. This upgrade establishes continuity and reliability of service with new telecommunications hardware and software at MFC, the Critical Infrastructure Test Range Complex (CITRC), CFA, and Waste Management Facility dial rooms. INL also completed Phase 1 of an electrical power upgrade, which will provide redundant power and upgrade communications to the north end of MFC. It is the first of several power upgrades to MFC. Finally, INL upgraded the sewage transport and lagoon system, replacing a leaking system and increasing capacity. 


\subsection{Balance of Site}

Eight facility areas are located on the INL site, which occupies an 890-square mile of otherwise undeveloped, high-desert terrain. Buildings and structures are clustered within these facility areas, which are typically less than a few square miles in size and separated by miles of open land. CFA, centrally located on the INL site, is the main sitewide services and support area for the two main DOE-NE R\&D campuses, ATR and MFC. Also located on the INL site are three primary non-DOE-NE facility areas: the Idaho Nuclear Technology and Engineering Center (INTEC), RWMC, and Naval Reactors Facility (NRF). Other smaller areas include CITRC and SMC.

INL depends on the DOE-EM owned and operated RWMC for disposal of remote-handled LLW from continuing operations. This is expected to continue until the Subsurface Disposal Area at RWMC is full or until it must be closed in preparation for final remediation.

Sitewide area infrastructure consists primarily of roads, railroads, power distribution systems, and communication systems that serve and connect facility areas.

\subsubsection{CFA}

CFA supports N\&HS R\&D, including the Wireless National User Facility with three independent network operations centers for testing, along with materials testing and development. The remoteness of CFA and other site locations, along with the quiet radiofrequency spectrum, makes this area a unique and desirable location for a national user facility wireless test bed. In addition, the Scoville Power System is a critical resource for electric-grid power testing.

Support services provided from CFA include medical, emergency response, transportation, equipment maintenance, security, communications, electrical power SCADA center, craft support, warehousing, and instrument calibration (Figure 2-5).

INL developed a CFA consolidation plan in FY 2012 detailing a campus dedicated to N\&HS wireless research and development missions. It also promotes space-management and land-use initiatives directed toward improving space utilization and reducing cost by consolidating and collocating office and laboratory space.

\subsubsection{CITRC Area}

The CITRC area serves the INL N\&HS missions, including program and project testing (i.e., critical infrastructure resilience and nonproliferation testing and demonstration). Activities that take place at the CITRC area include wireless test-bed operations, power line and grid testing, unmanned aerial vehicle testing, accelerator testing, explosives detection, and radiological counter-terrorism emergency-response training. An electric-grid test bed is planned at INL near the CFA/CITRC area, which will provide a new reconfigurable test substation and several miles of transmission and distribution lines.

\subsubsection{SMC}

SMC has been manufacturing armor packages for the U.S. Army Abrams main battle tank since 1984. Located at the north end of the 890 -square mile INL site, this 25 -acre armor-manufacturing complex provides $320,000 \mathrm{ft}^{2}$ of secure floor space and state-of-the-art equipment. Capabilities at the SMC complex include light and heavy fabrication equipment and a state-of-the-art metallurgical laboratory. 


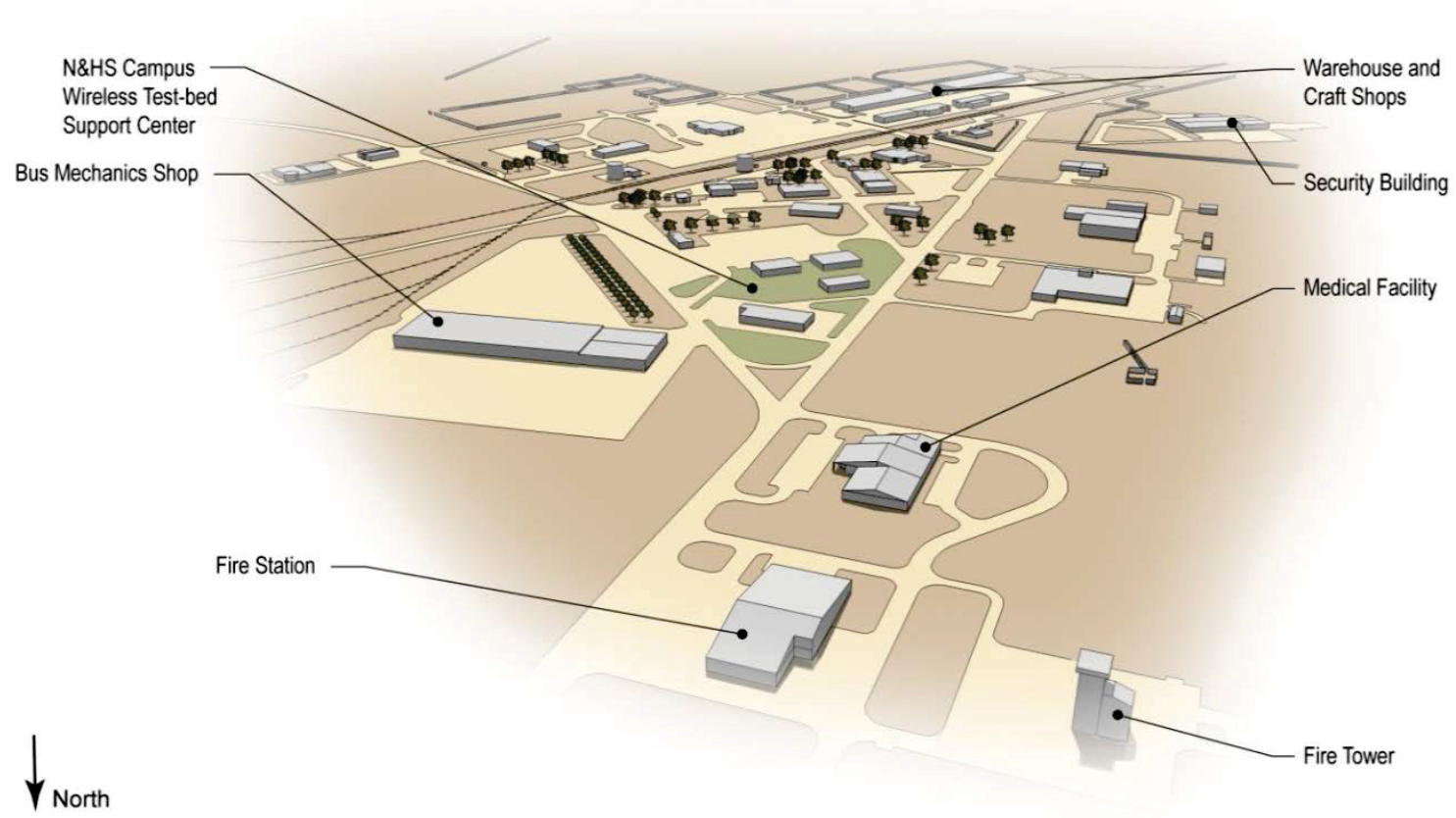

Figure 2-5. Central Facilities Area.

\subsubsection{INTEC}

Currently owned and operated by DOE-EM, INTEC operated until 1992 to recover HEU from UNF from government reactors and convert the resulting liquid high-level waste into a more stable, solid granular material suitable for long-term storage (Figure 2-6). Today, with environmental cleanup of INTEC nearing completion, most of these facilities are, or will be, surplus to ICP and the DOE-EM mission.

INL completed the Material Security and Consolidation Project, repurposing the Unirradiated Fuel Storage Facility (CPP-651), and several surrounding buildings for the relocation of LEU disposition product from a sodium-bonded spent nuclear fuel campaign.

While other INTEC facilities are candidates for reuse to support DOE-NE and/or the multiprogram mission needs, development of a business case analysis that considers utilization and life cycle costs is needed to help inform future decisions. Resources at INTEC include the Remote Analytical Laboratory (RAL), a 13,000- $\mathrm{ft}^{2}$ facility designed for a number of organic, inorganic, and radioanalytical capabilities. Other resources include fuel handling and storage facilities such as the Fluorinel Dissolution Process and Fuel Storage (CPP-666) Facility, including the Fuel Dissolution Process Cell; the CPP-603 used fuel storage facility; and the CPP-2707 used fuel storage pad. 


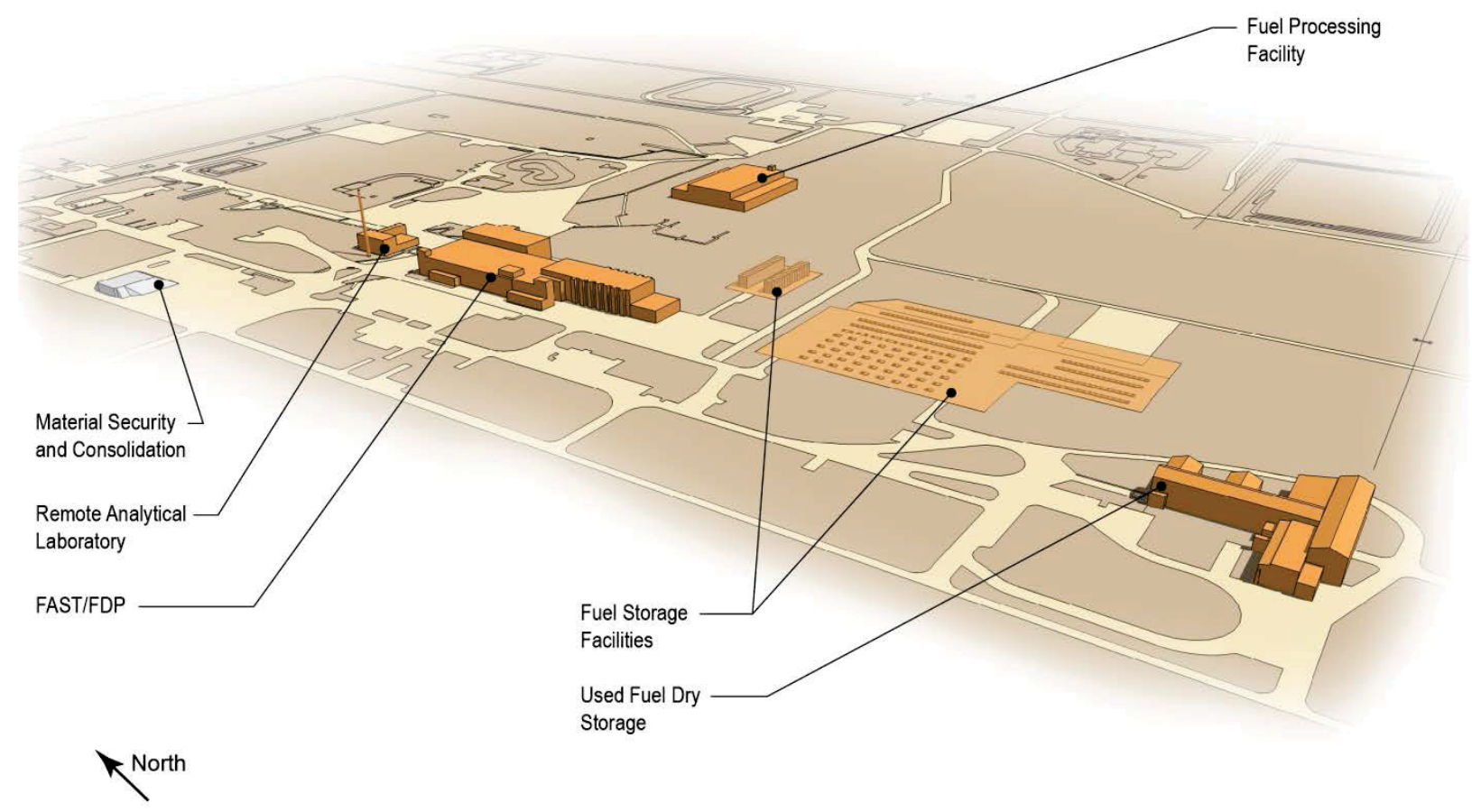

Figure 2-6. Idaho Nuclear Technology and Engineering Center.

\subsection{Idaho National Laboratory Strategic Sustainability}

INL implements sustainable practices in facility design and operation, procurement, and program operations that meet the requirements of the following documents:

- Executive Order (EO) 13514, "Federal Leadership in Environmental, Energy, and Economic Performance"

- EO 13423, "Strengthening Federal Environmental, Energy, and Transportation Management"

- The "Energy Independence and Security Act of 2007" (PL 110-140)

- $\quad$ The DOE Strategic Sustainability Performance Plan (SSPP; DOE 2012a)

- $\quad$ The FY 2013 INL Site Sustainability Plan (SSP; DOE-ID 2012).

The INL Sustainability Program seeks to achieve measurable and verifiable energy, water, and greenhouse gas reductions; responsible use and disposal of materials and resources; and cost-effective facilities, services, and program management. The INL Sustainability and Energy Management Program is captured in the SSP (DOE-ID 2012). INL continues to mature its comprehensive leadership strategy to address the execution gaps identified in Appendix D by refining the investments needed to meet its goals. 


\section{IDAHO NATIONAL LABORATORY CORE CAPABILITIES}

INL maintains core nuclear energy R\&D capabilities in irradiation testing, PIE, fuel fabrication, advanced separations, waste form development, and final assembly and testing of radioisotope power systems. These comprise reactors, hot cells, and other specialized laboratory facilities that are able to support research using highly radioactive materials; they are essential to DOE-NE research and accessible to the broader nuclear energy R\&D community. INL also maintains capabilities in critical infrastructure protection; nuclear nonproliferation; energy, environment, and fundamental research; and engineering.

\subsection{Steady-State Irradiation}

ATR is a materials and fuels test reactor with thermal neutron fluxes of $1 \times 10^{15}$ neutron $/ \mathrm{cm}^{2}$-sec and maximum fast $(\mathrm{E}>0.1 \mathrm{MeV})$ neutron fluxes of $5 \times 10^{14}$ neutrons $/ \mathrm{cm}^{2}$-sec. These fluxes, combined with its 77 irradiation positions, make ATR a mission-critical (MC) facility with a unique, versatile thermal irradiation capability. The reactor accommodates static, sealed capsule tests with passive instrumentation, tests with active instrumentation for measurement and control of specific testing parameters, and pressurized water loops that allow testing of materials and fuels under representative plant conditions (e.g., pressure, temperature, flow, and chemistry). A hydraulic shuttle irradiation system allows for shortduration irradiation tests. TTAF $\left(4,200 \mathrm{ft}^{2}\right)$ supports the precision work associated with experiment assembly for insertion in the reactor. A newly installed pressurized water reactor loop is currently in use by EPRI for LWR sustainability research.

Establishing the ATR NSUF brought a sustained focus on enabling high-quality experiments through improved experiment design, control, and instrumentation to achieve capabilities that compare to, if not exceed, top test reactors worldwide. Improved instrumentation is a key aspect of this capability, and the continual deployment of new sensors at ATR enables better experimental control and data acquisition from scientific investigations, such as embrittlement behavior of pressure vessel steels, degradation of core structural materials by irradiation, and demanding tests on fuel performance limits.

Located in an extension of the ATR canal, ATRC is a full-size, low-power, pool-type nuclear replica of ATR used to evaluate prototypical experiments before they take place in ATR. There is increasing demand for use by researchers, and ATRC is running for longer periods to accommodate experiments. Its normal operating power level is approximately $100 \mathrm{~W}$, with a maximum power rating of $5 \mathrm{~kW}$.

\subsection{Transient Irradiation}

In December 2010, DOE-NE approved the mission need for resumption of transient testing; alternatives to meet the mission need are currently being evaluated. Transient testing capability is needed to support the DOE-NE R\&D mission by helping establish an understanding of fuel performance phenomenology at the millisecond-to-second time scales. It supports Research Objectives 1 through 3 of the DOE-NE Roadmap, to understand and predict LWR performance, develop innovative fuel designs for existing LWRs and advanced reactors, and develop advanced TRU-bearing fuels for the Fuel Cycle Research and Development (FCRD) Program.

Transient testing would screen advanced fuel concepts, including accident tolerant fuels, by allowing for early identification of the limits of fuel performance. It would also focus fuel development from various viable options, ultimately reducing the time and cost required to develop new fuels. 
The United States has not performed transient testing for over a decade but has retained a capability to do so with the TREAT reactor, currently in cold standby and maintained to enable use of its floor space for alternative mission work. TREAT can conduct tests on full-size fast reactor fuel and 36-in. segments of LWR fuel. During previous missions, TREAT performed 6,604 startups and 2,885 transient irradiations.

\subsection{Fresh Fuel Characterization and Postirradiation Examination}

Characterization and PIE capabilities at MFC are located in HFEF, AL, EML, and FASB. PIE capabilities are also being established in IMCL. In addition, the CAES Microscopy and Characterization Suite (MaCS) is located in an NRC-licensed facility that focuses on characterization using microgram or nanogram quantities of irradiated material specimens downsized and prepared at MFC. MaCS is operational, and its equipment includes a local electrode atom probe, a FIB, a TEM, an atomic force microscope, and a SEM. The NSUF is a portal for national and international research teams to perform research in MaCS. Collectively, these resources are adequate to serve basic needs for fuel examination, material handling, and waste disposal, and to provide the foundation for world-leading PIE capabilities.

Handling large quantities of irradiated fuel at the assembly scale must be carefully controlled and conducted in heavily shielded hot cell facilities on a protected site, such as MFC. Conducting basic studies on small, low-hazard radiological specimens in a radiological laboratory environment rather than in a nuclear facility can be beneficial. The most effective research capabilities couple heavily shielded nuclear facilities with radiological characterization laboratories that contain high-end research equipment. INL is equipping the CAES facility with high-end equipment and is developing sample analysis capabilities that will ultimately be transferred to MFC to be used under highly radioactive conditions.

Sustaining world-leading capabilities for the next 40 to 60 years will require full utilization and sustainment of current facilities. To meet the growing needs for PIE anticipated over the coming decades, planning has begun to identify capabilities that would be required.

\subsubsection{Hot Fuel Examination Facility}

HFEF is a heavily shielded nuclear facility designed to be the front-end of the PIE capability. It can receive and handle kilograms to hundreds of kilograms of nuclear fuel and material in almost any type of cask, including full-size commercial LWR fuel. The mission of HFEF is to receive material, conduct nondestructive and destructive examinations, and prepare material specimens for transfer to characterization laboratories for detailed analysis. It also houses limited mechanical testing equipment, as well as the NRAD 250-kW TRIGA reactor for neutron radiography, bench-scale electrochemical separations testing, and engineering-scale waste-form development to support operations in FCF. HFEF will continue in its current mission, with refurbishment as needed to support the DOE-NE mission.

\subsubsection{Electron Microscopy Laboratory}

EML houses a TEM, a dual-beam FIB fitted with electron backscatter diffraction and microchemical analysis capabilities, and a state-of-the-art SEM fitted with a Wavelength Dispersive Spectrometer with software that allows semi-quantitative analysis of heavy actinides. EML will continue to function in this capacity although tight space makes R\&D less than optimal.

\subsubsection{Analytical Laboratory}

The AL focuses on chemical and isotopic characterization of unirradiated and irradiated fuels and materials. It receives small quantities of irradiated material from HFEF, performing dissolution and dilution in a series of analytical hot cells, followed by analysis of the diluted materials using 
instrumentation equipped with hoods or gloveboxes for radiological control. AL houses advanced instruments, including the state-of-the-art Inductively Coupled Plasma Mass Spectrometer, two Thermal Ionization Mass Spectrometers, and instruments for determining the fundamental thermodynamic properties of actinide-bearing materials. AL will continue its current mission with regular maintenance and refurbishment, as required, to maintain capabilities.

\subsubsection{Fuels and Applied Science Building}

FASB provides the resources to perform fuel development, materials characterization, and irradiated materials testing. It houses a low-level, thermophysical properties laboratory, outfitted with equipment for sample preparation, optical microscopy, electron microscopy, and thermodynamic properties determination. It is also equipped with a suite of lead-shielded gamma cells to conduct environmental crack-growth-rate and fracture-toughness testing on irradiated materials. This testing enables examination of larger specimens providing quantitative data on the effects of reactor environments upon which to base science-based determinations of reactor life extension. FASB will continue to transition out of a fuel development mission to a radiological characterization and mechanical testing capability.

\subsubsection{Irradiated Materials Characterization Laboratory}

A multipurpose facility suitable for many different missions, IMCL will initially house modern, state-ofthe-art PIE instrumentation. It is designed specifically for advanced instrumentation and equipment, serving as a prototype to inform future PIE needs. IMCL is the next step in making specialized nuclear research capability available to the larger DOE-NE research community by housing advanced microstructural characterization equipment. It contains space for installation of instruments, equipment, and shielding structures that can be redesigned and refitted whenever necessary. Specialized equipment includes mechanical systems that tightly control temperature, electrical and magnetic noise, and vibration to the standards required for advanced analytical equipment.

\subsubsection{Advanced PIE}

Existing PIE capabilities at DOE laboratories, universities, and in the private sector are widely distributed. Current PIE capabilities such as those being established in IMCL serve basic needs for fuel examination, material handling and waste disposal but are limited in their ability to function on micro-, nano-, and atomic-scale levels. A better understanding of nuclear fuels and material performance in the nuclear environment can assist in the development of innovative fuels and materials required for tomorrow's nuclear energy systems. Characterizing radioactive samples at the nano-scale to micro-scale length resolutions should also support the development of modern computer codes that could enable order-of-magnitude improvements in the time and cost of developing new fuel. Technical option studies are underway to determine if advanced PIE capabilities are needed in the future.

\subsubsection{National Scientific User Facility}

NSUF activities are centered at the CAES facility. CAES houses high-end PIE instruments that are accessible to visiting user-facility researchers, enabling them to collaborate in DOE-NE research programs. The CAES research facility operates in the same manner as universities. For low-risk radiological research, it provides a cost-effective, innovative, and productive environment to explore fundamental science questions and execute basic research that compliments INL research. CAES holds an NRC license through Idaho State University that has material quantity limits sufficient for handling low-activity specimens. These research tools position CAES to be a major regional center for materials characterization. REL will house additional office and laboratory space for NSUF. 


\subsection{Experimental Fuel Fabrication and Process Development}

Comprehensive nuclear fuel fabrication capabilities at INL: (1) support R\&D on multiple fuel types and all hazard levels, (2) support work requiring fume-hood-handling to remote hot-cell-handling, and (3) supply bench and lab-scale quantities of actinide elements in both metal and oxide forms to research programs. Much of the existing MFC equipment and supporting infrastructure for metal fuel development can also support fabrication and characterization of ceramic and intermetallic fuels, thereby leveraging existing infrastructure to expand capabilities while reducing costs.

Capabilities at AL will expand to fabricate TRU containing metallic fuels, facilitate the controlled casting of TRU containing metallic fuels, and allow for the investigation of volatilization rates of the TRU elements during the casting process. The capability to fabricate fuel remotely to support a CRADA with the Republic of Korea and prepare for eventual transient irradiation testing of pre-irradiated fuels is planned for FY 2017. Development of the neptunium-oxide reduction capability is also underway to supply program feedstock and meet some international needs for metal feedstock.

FMF supports laboratory-scale development and assembly of TRU metal and ceramic fuels for the Advanced Fuel Cycle Initiative. Americium distillation is being developed in FMF, and americium oxide reduction will be pursued in FY 2014.

FASB houses uranium glovebox lines for developing new fuel types for converting research and test reactors from HEU to LEU fuel. It supports fuel development R\&D such as prototyping of transmutation fuel fabrication processes for fuel-cycle R\&D. FASB houses unique uranium fabrication capabilities and is dedicated to characterization of fresh uranium fuel.

EFF supports fuel fabrication R\&D for oxides, nitrides, carbides, silicides, and composite fuels — all forms that may offer advantages over current commercial fuel technologies.

\subsection{Separations and Waste Form Research}

Over the last decade, DOE sponsored research on two broad categories of technologies for group separation of actinides: (1) advanced aqueous processes and (2) molten salt electrochemical techniques. For aqueous processes, a suite of advanced flow sheets was demonstrated at the laboratory and bench scale. Electrochemical processing is currently used to disposition fast reactor fuels and conduct research on group separation of actinides. Waste form R\&D is also conducted in close coordination with the separations processes at the bench and laboratory scale, and in the case of electrochemical processing, at the engineering scale.

\subsubsection{Aqueous Separations}

Cold laboratory-scale testing for aqueous systems takes place at IRC. Engineering/pilot-scale cold surrogate testing for aqueous systems takes place in Idaho Falls at the BCTC laboratory. Additional laboratory-scale flowsheet capabilities to support the critical materials hub will be established at BCTC in FY 2014. Warm (radiotracers and glovebox work) laboratory/bench-scale testing and analytical capabilities exist at CFA and the MFC AL and RCL, while nonradiological separations and waste form R\&D will be housed in REL (planned availability in FY 2015). Additionally, a state-of-the-art Cobalt-60 gamma irradiator with a radiolysis/hydrolysis test loop is located at FASB. DOE's progression to integrated laboratory-scale testing may require a larger hot cell facility, waste management support systems, and enhanced S\&S measures. 


\subsubsection{Electrochemical Separations}

The electrochemical separations process uses electrochemical and metallurgical techniques at elevated temperature in the absence of water and other neutron-moderators, enabling processing of highly fissile materials without extreme dilution. The intent is recovery of uranium and group actinides and conditioning of the fission products into stable waste forms.

Used sodium-bonded Experimental Breeder Reactor II (EBR-II) and Fast Flux Test Facility (FFTF) fuel is being prepared for processing and disposition in engineering-scale equipment installed in FCF at MFC, with additional waste form equipment planned for installation in HFEF.

Gram-scale electrochemical experiments are supported in a nonradiological laboratory for investigations with surrogate materials in FASB for experiments with low-activity materials (i.e., depleted uranium $[\mathrm{DU}]$ or thorium), and in HFEF for experiments with irradiated materials.

\subsection{Used Fuel Storage and Transportation Research, Development, and Demonstration}

The DOE-NE FCRD Program is chartered to identity alternatives and conduct scientific research and technology development to effectively manage (i.e., store, transport, and dispose) UNF and waste generated by existing and future nuclear fuel cycles. The Used Nuclear Fuel Storage and Transportation Research, Development, and Demonstration Plan (DOE 2012b) outlines DOE's approach for conducting RD\&D to address the concerns and ensure safe and secure storage and transportation of the nation's UNF until final disposition is achieved.

Capabilities at INL that may be able to support this mission include: (1) the AL and IMCL at MFC; (2) existing commercially designed dry storage facilities at INTEC; and (3) the ability to receive large fuel rods or materials, prepare samples, and move the material to testing equipment locations without having to repackage for movement to another facility. Development and testing of monitoring and inspection devices and sensors are in the early stages.

\subsection{Radioisotope Power Systems}

DOE-NE commissioned SSPSF in FY 2004 for final assembly and testing of radioisotope power systems. This facility provides one-of-a-kind capabilities and is operational and fully staffed for fueling, testing, and delivering radioisotope power systems. It houses three fueling glovebox lines, including one equipped to meet NASA planetary protection protocols. It also houses a vibration test apparatus to simulate launch pad scenarios, a magnetic-moment measuring device, and a mass-property-measuring device. Finally, there are two thermal vacuum chambers, one equipped to employ liquid nitrogen cooling for simulating space environments and one for assessing power output. Its full delivery system is comprised of two specially equipped trailers and three type-B shipping containers for delivering the final power systems to the customer's location.

\subsection{National and Homeland Security}

INL provides leadership and innovative solutions to many significant national security challenges (e.g., Global Threat Reduction Initiative, National Infrastructure Protection Plan). N\&HS capabilities reside in unclassified and secured offices and laboratories equipped with communication and network connectivity for onsite and remote command and control, computer emulation, modeling and simulation, and real-time testing and demonstration and include broad use of INL facilities, test ranges, and the full-scale infrastructure for training and technology RD\&D. Capabilities focus on current and urgent national challenges such as: 
- Enable the war fighter, intelligence community, and first responder

- Ensure a secure and resilient electric grid

- Support wireless security and spectrum bandwidth limitations

- Secure industrial control systems across critical infrastructure sectors

- Protect against nuclear and radiological threats

- Sustain nuclear nonproliferation safety and safeguards.

Critical infrastructure protection RD\&D uses offices, including secured space, within REC, CFA, and CITRC. Programmatic RD\&D occurs in laboratories and test facilities within REC, CFA, and INL site field-testing areas for the Wireless Test Bed and the National Security Test Range. Critical infrastructure protection electrical power-grid testing routinely uses part of the INL operating power grid for full-scale testing. Other field-testing activities use facilities and areas across the INL site, as available, at CFA, MFC, Test Area North (TAN), and INTEC. Facilities in Idaho Falls support national security threat analysis and technology R\&D for nonproliferation and critical infrastructure protection.

Nonproliferation RD\&D uses offices, including secured space, within REC and MFC. Programmatic RD\&D occurs in laboratories and test facilities within dedicated laboratories in REC facilities, shared field-testing areas at CITRC and CFA, and in collaboration with nuclear facilities at MFC and ATR.

\subsection{Energy and Environment}

INL maintains a large number of engineering development laboratories that support energy systems prototype development and testing. These include large, high-bay space housing prototype biomass conversion equipment, liquid-metal hydrogen generation systems, complete biomass processing units, grinders, thermal treatment units, chemical treatment and extraction systems, densification systems, synthesis gas-generation and process-integration test stands with associated controls and data acquisition systems, and high-temperature test chambers for heat exchangers and other devices. Numerous analytical laboratories support these programs, including those that assess physical, chemical, rheological, and structural characteristics of biomass.

INL maintains $15,000 \mathrm{ft}^{2}$ of laboratory space for advanced vehicle and energy storage testing. This infrastructure supports development of materials and process chemistry for innovative energy storage devices, and accommodates testing of research-sized coin cells through full vehicle systems. It houses over 650 battery test channels, environmental chambers, a shake table, and related battery testing equipment and test vehicle platforms.

INL also maintains laboratories that support chemical analysis; chemical separations, materials development and materials testing functions for the nuclear energy research mission; and advanced manufacturing, energy storage, and advanced process development for industry. In addition, it provides laboratory space supporting R\&D of new chemical production processes and chemical separations systems.

Commissioning of REL will significantly enhance the chemical processes capability base at INL to support research on the nuclear fuel-cycle, site stewardship, industrial processes, and advanced energy generation. 
INL has core capabilities to monitor, assess, and mitigate environmental consequences and risks associated with national challenges related to energy-consequent activities such as fossil energy extraction. Critical infrastructure supporting these capabilities includes geochemistry and mechanics laboratories (including a geocentrifuge), chemical and radiological assay laboratories at the ATR Complex, and chemical assay laboratories at REC in Idaho Falls.

\subsection{Scientific Computing}

Advances in scientific computing over the last 40 years have made it possible to simulate scientific systems at a scale from smallest to largest, and to a much greater degree of fidelity than previously possible. Modeling and simulation is a powerful tool that can be combined with experimental data to reduce design and testing time, uncertainties associated with models, and the burden on infrastructure.

The INL HPC Data Center, located in EROB, supports INL fuel development and other reactor development needs, including those of other national laboratories and users. Expanding the HPC Data Center may be required to house expanding scientific computing needs. 


\section{IDAHO NATIONAL LABORATORY ENABLING INFRASTRUCTURE}

INL has five types of enabling infrastructure that support mission-driven core capabilities and allow them to function most effectively:

1. Utilities and supporting infrastructure

2. Nuclear materials management infrastructure

3. Waste management infrastructure

4. Information management infrastructure

5. Laboratory protection services infrastructure.

\subsection{Utilities and Supporting Infrastructure}

Supporting infrastructure consists primarily of real property assets (e.g., buildings, trailers, utility systems, and roads) that enable INL's core R\&D capabilities and mission critical facilities. INL real property infrastructure includes 485 DOE-NE-owned and operating real property assets, with a total Facility Information Management System (FIMS) replacement plant value of \$2,849 million. These assets include 285 operating buildings ${ }^{\mathrm{b}}$ totaling 2.3 million $\mathrm{ft}^{2}$, and 200 nonprogrammatic ${ }^{\mathrm{c}}$ other structures and facilities (OSFs). OSFs include real property assets that are: (1) not buildings (e.g., bridges, communications towers, roads, and railroads) and (2) site utility systems that collect or distribute utility services (e.g., steam, electricity, compressed gases, liquid waste streams, natural gas, and water).

\subsection{Nuclear Materials Management Infrastructure}

The INL mission requires access to a variety of SNM. Responsible management of these materials is fundamental to ensuring the availability of nuclear material, when needed. This requires appropriate facilities and the infrastructure capabilities to store and handle Safeguards Category I quantities of SNM. These unique assets not only enable INL to perform its missions but also to attract other R\&D organizations.

The overall nuclear material management strategy of INL is to obtain/retain and make accessible materials needed to support $R \& D$, dispose of unneeded materials to reduce liabilities, and ensure the safe and efficient handling and storage of nuclear materials. The following facilities and capabilities are key elements of this strategy.

MFC houses a variety of gloveboxes and other equipment to stabilize a significant portion of INL surplus materials for future use or disposition. MFC also supports visual inspections of nuclear materials to ensure appropriate storage configurations.

INL completed refurbishing the 4,600- $\mathrm{ft}^{2}$ Materials Security and Consolidation Facility (formerly the Unirradiated Fuel Storage Building [CPP-651]) at INTEC in 2013. This facility will serve as a storage location for INL nuclear materials.

b. The term "operating buildings" includes all operating buildings and real property trailers that have a FIMS status of operating (status codes 1, 2, and 6).

c. Nonprogrammatic OSFs include all FIMS OSF assets except 3000-series OSFs like the Advanced Test Reactor, its cooling tower and the Transient Reactor Evaluation and Testing (TREAT) reactor. 


\subsection{Waste Management Infrastructure}

DOE-EM and DOE-NE have complementary infrastructure to support INL's waste management activities. Both organizations have waste storage pads and waste disposition infrastructures that directly support their individual missions, and both actively utilize each other's capabilities when needed to ensure minimal duplication of infrastructure. DOE-NE owns 11 waste management facilities that directly support newly generated waste from ongoing operations, including R\&D programs. DOE-NE uses some of the 25 DOE-EM-owned waste management facilities where it is not cost effective to maintain duplicative capabilities or when DOE-NE's waste stream is small compared to DOE-EM's waste volumes.

DOE-NE with NR is proposing a replacement facility for onsite disposal of remote-handled low-level waste (LLW). DOE-EM will maintain existing onsite remote-handled disposal capability until the facility is full. The Remote-handled LLW Disposal Project will provide onsite replacement of disposal capability. DOE-NE is planning for the Remote-handled LLW Disposal Facility to be a Hazard Category 2 nuclear facility, consisting of up to 500 below-grade precast concrete vaults, designed to emplace and dispose of remote-handled LLW generated onsite for a minimum of 20 years. DOE-NE requires this capability to support ongoing and future programs (including DOE-NE and NR) at INL.

\subsection{Information Management Infrastructure}

INL maintains a significant information management (IM) infrastructure, including HPC and business computing centers, network infrastructure, a substantial fiber backbone, and dial rooms. This infrastructure supplies all internet, intranet, email, forms, scientific and engineering data, as well as business applications, business data, telecommunications data, safety alarms, and emergency systems data. Within the next 10 years, plans are in place to replace a portion of the aging fiber backbone at MFC to ensure uninterrupted support to research, operational and business communications. INL also plans facility enhancements that support classified computing system upgrades during this same period.

\subsection{Laboratory Protection Services Infrastructure}

Laboratory Protection (LP) at INL deploys a suite of emergency services to protect laboratory missions, personnel, property, and the environment:

- Security infrastructure includes protective force training facilities, security fences, alarm stations, and personnel and vehicle inspection stations to protect INL's assets and people in a manner consistent with Departmental regulations.

- Emergency response infrastructure includes the INL Emergency Operations Center in Idaho Falls and four emergency control centers located at INL.

- Fire department emergency response functions are deployed through three fire stations that provide emergency response services to all missions conducted on the INL site, as well as the transportation corridors that pass through INL.

- Occupational Medicine operates five dispensaries sitewide. Services include drug screening; medical and psychological evaluations; and emergency medical and psychological care with advanced cardiac life support, 24/7 nursing services available at CFA, chelation therapy, a decontamination facility, and $\mathrm{x}$-ray capability at two locations. 


\section{INVESTMENT STRATEGIES}

As part of the ten-year vision for sustainment, DOE-NE and INL are committed to implementing a proactive, mission-driven, risk-based approach to sustain the readiness of mission-supporting infrastructure. The following are key elements of the strategy for sustaining INL utilities and supporting infrastructure:

- Effective management of the capabilities provided by enduring assets

- Investment in new supporting infrastructure to continue to reliably support current missions and make new mission capabilities possible

- Implementation of sustainability concepts into enduring and new infrastructure assets to enhance energy and water efficiency and improve employee health and productivity

- Efficient and timely disposition of nonenduring assets.

To maximize the value of available funding resources, DOE-NE and INL are updating infrastructure with attributes that promote collaboration, modernization, flexibility, and sustainability. The investment strategy is to build upon existing infrastructure and acquire a few new real property assets. DOE-NE and INL base this strategy on a business case that recognizes the economy and efficiency of investing in existing resources relevant to DOE-NE and multiprogram nuclear and energy security missions. Looking forward, DOE-NE and INL will focus on sustaining and revitalizing core capabilities and establishing a financially realistic plan to use existing infrastructure efficiently, regardless of location.

In FY 2012, DOE-NE and INL made notable progress toward the infrastructure plan by completing several construction projects at MFC including IMCL building construction, the EFF facility conversion to enable R\&D related to fuel fabrication, power upgrades, and the sewage lagoon replacement. Early in FY 2013, construction was completed on the Materials Security and Consolidation Facility establishing additional storage for INL nuclear materials. At REC, ESL began operations enabling enhanced R\&D capabilities for biofuel feedstock process demonstration, hybrid energy systems testing, and battery testing.

\subsection{Defining Investment Needs}

As stated above, DOE-NE's goal is to utilize existing infrastructure to the extent practical to support mission activities before proceeding with new construction or additional lease facilities. DOE-NE and INL assess infrastructure needs through a closely linked process that focuses first on ascertaining mission requirements and then on assessing the existing infrastructure to identify gaps or excess capacity. As outlined in Chapter 1, the major real property holdings at INL are linked to DOE-NE programmatic mission needs. Consistent with DOE Policy and before proceeding with surplus facility activities, DOE-NE and INL analyze any additional capacity to determine its potential for future use by customers within DOE or other federal agencies.

Some significant infrastructure gaps will develop within the next 10 years, two of which DOE is already actively addressing:

- The anticipated closure of concrete vaults at the RWMC Subsurface Disposal Area, which provide onsite remote-handled LLW disposal capability. DOE expects that the vaults will reach capacity by 2020, which will have an impact on DOE-NE and NR missions. Therefore, DOE-NE and NR are proposing a replacement facility located adjacent to the ATR complex to provide up to 20 years of additional storage capacity. 
- The lack of a domestic capability for transient testing of nuclear fuel. DOE-NE has identified a need to resume transient testing to support $\mathrm{R} \& \mathrm{D}$ missions and has commenced technical and environmental studies to assess options for filling the gap using existing infrastructure within the DOE complex. Two alternatives are under analysis: restarting the TREAT reactor at INL or using the Annular Core Research Reactor at Sandia National Laboratory. An outcome of the analysis may include the modification or construction of real property to support mission goals.

Additional infrastructure gaps (i.e., advanced PIE capabilities) exist, and studies will continue to clarify associated needs, schedules, and potential solutions for those gaps.

In addition to closing gaps, INL needs to refurbish, maintain, and repair existing infrastructure. Many existing INL facilities are over 30 years old and require system or facility refurbishment to maintain a safe, secure operating environment. Appendix A contains an assessment of the INL Real Property Infrastructure, an essential mission-enabling capability; it describes and discusses INL's strategy for managing utilities and supporting infrastructure, as well as a proactive approach to sustaining real property assets. It also discusses deferred maintenance backlog, replacement plant value, and asset condition index (ACI) for the mission critical and mission-dependent buildings and OSFs. Appendix B, Table B-1 highlights the current plan to build and refurbish supporting infrastructure.

Table 5-1 provides a high-level summary of identified infrastructure gaps and associated actions. Appendix B outlines the investments directed toward addressing the gaps identified in Table 5-1. 


\begin{tabular}{|c|c|c|c|c|c|c|}
\hline & 逽 & 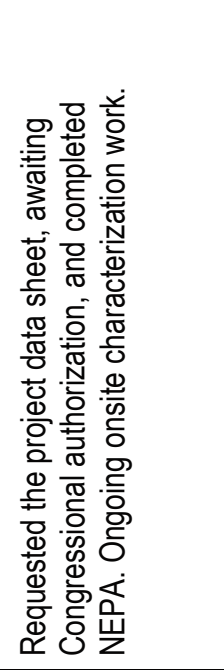 & 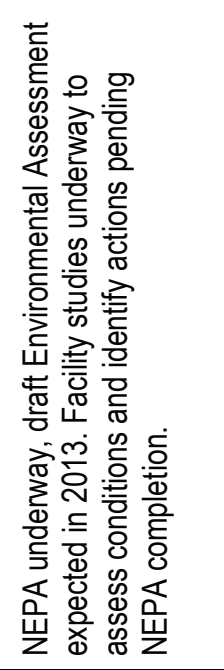 & 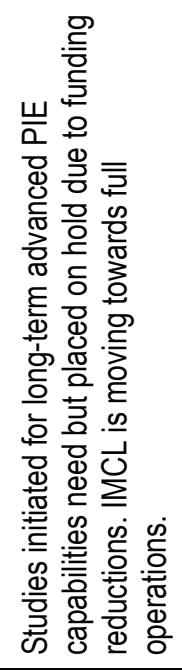 & 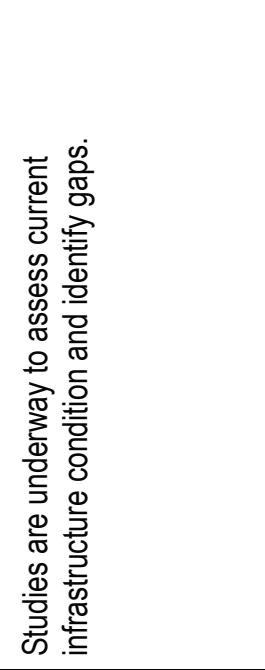 & 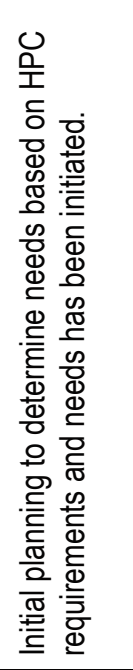 \\
\hline 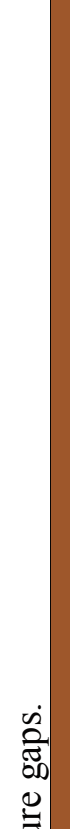 & 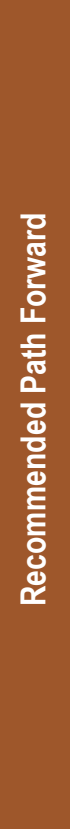 & 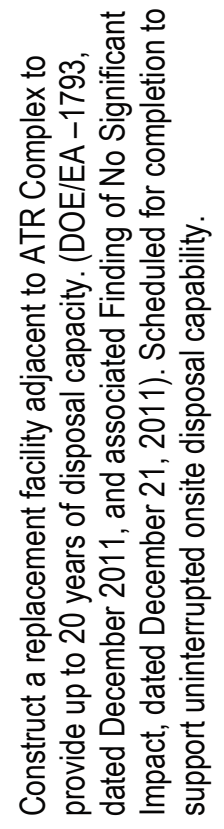 & 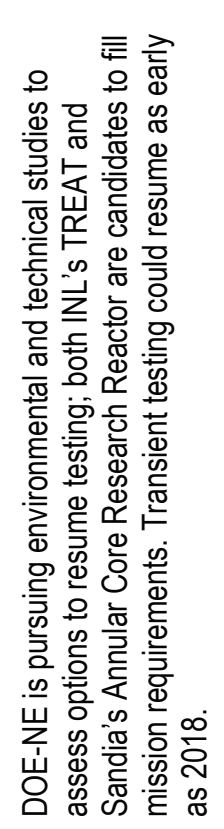 & 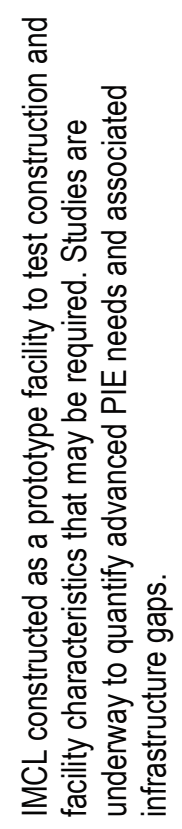 & 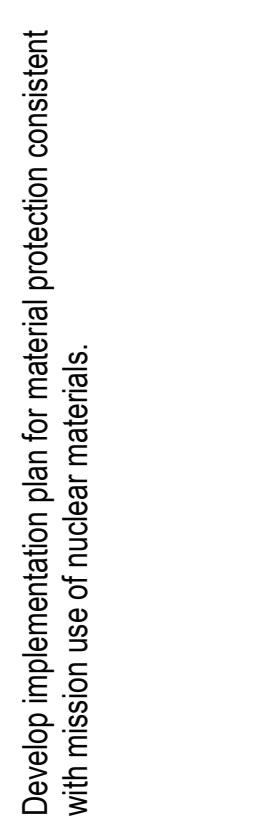 & 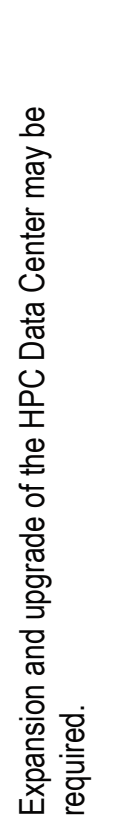 \\
\hline 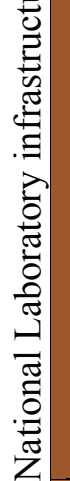 & 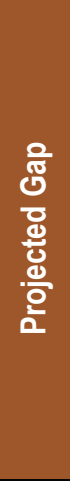 & 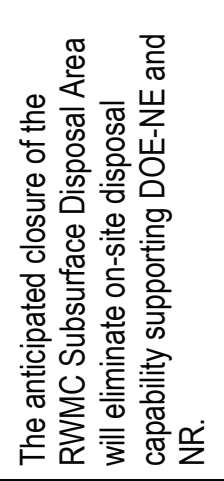 & 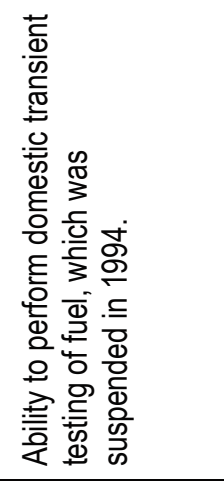 & 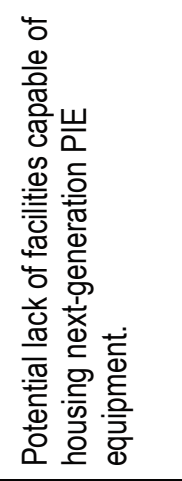 & 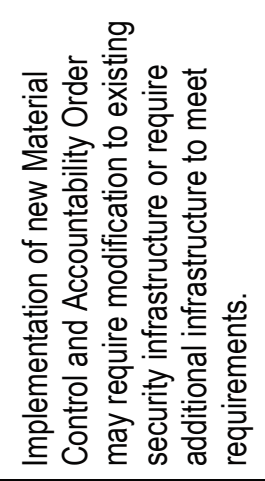 & 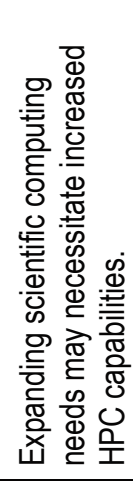 \\
\hline 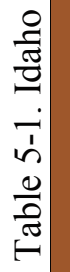 & 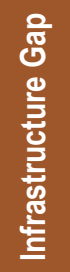 & 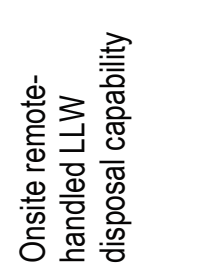 & 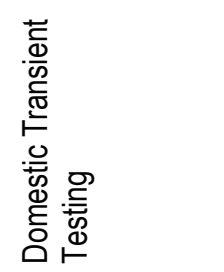 & 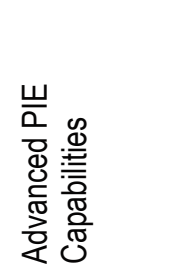 & 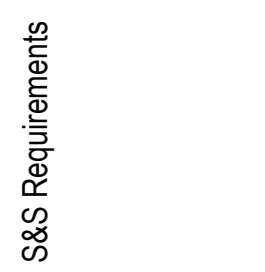 & $\begin{array}{l}\text { 몸 } \\
\text { 年 }\end{array}$ \\
\hline
\end{tabular}




\subsection{Investment Approach}

A multifaceted investment strategy leverages program, facility maintenance, strategic, and work-forothers investments to maintain and refurbish infrastructure at INL to the level allowed by anticipated funding. This integrated investment portfolio seeks to optimize available funding. DOE-NE and INL continue to investigate funding alternatives and pursue cost efficiencies through consolidation, laboratory integration, and footprint reduction to better utilize available resources. Figure 5-1 summarizes the INL real property investment resource requirements associated with TYSP implementation.

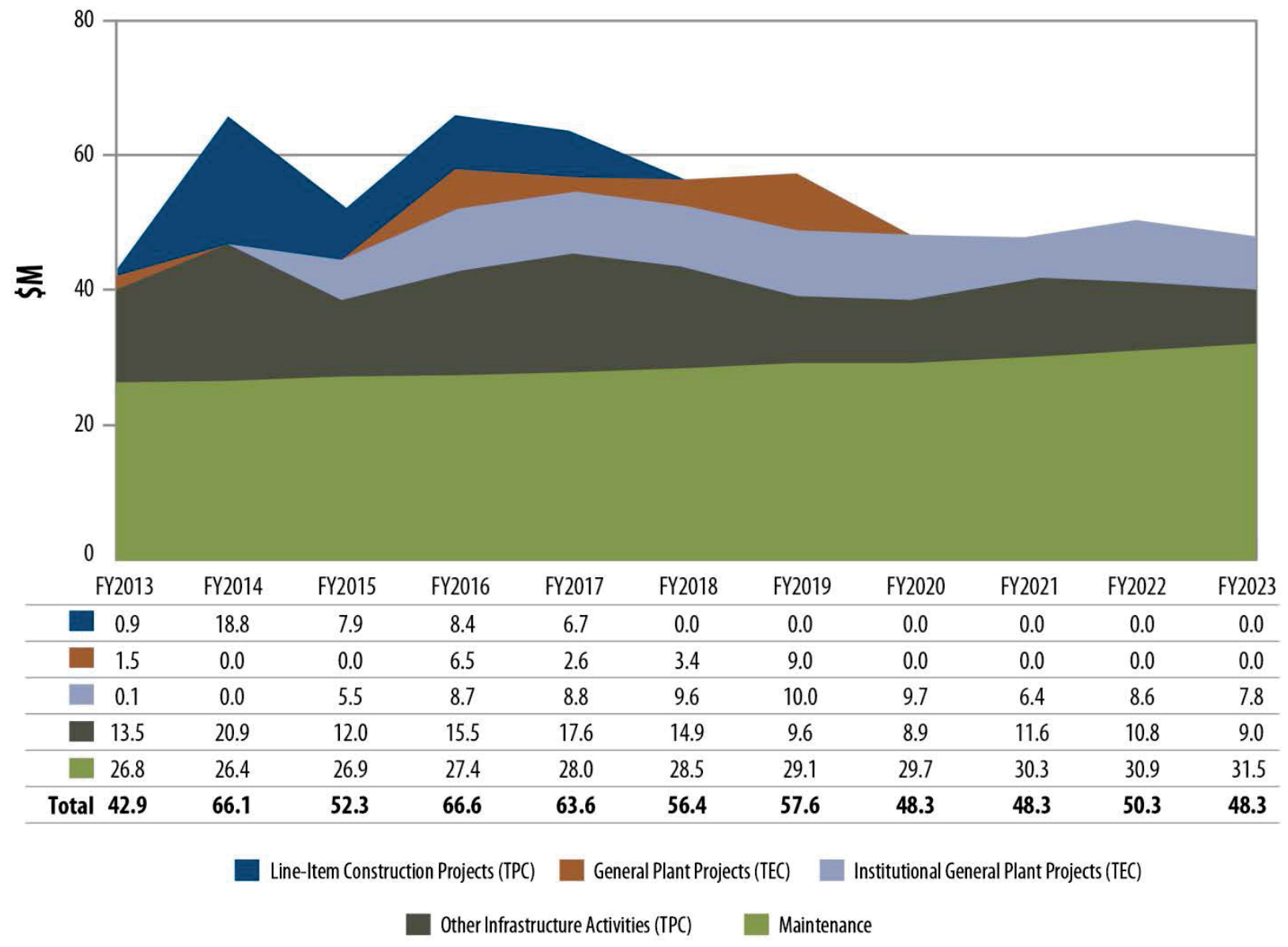

Figure 5-1. Projected Idaho National Laboratory facilities, sustainment, and disposition needs.

\subsubsection{Program Investments}

- DOE-NE supports maintenance and repair of nuclear facilities and it funds major maintenance and repair of nuclear infrastructure, disposition of nonnuclear facilities, and assessments for development of new or replacement capabilities. The real property investments identified in Tables B-2 (Programmatic General Plant Projects [GPPs]) and B-3 (Line-item Construction Projects) are supported through DOE-NE programmatic investments. 
- DOE-EM, consistent with DOE-NE, provides funds to maintain existing infrastructure supporting the DOE-EM clean-up mission, identifies gaps, and constructs new facilities such as the Integrated Waste Treatment Unit. DOE-EM also invests in the decommissioning and demolition (D\&D) of unneeded footprint, including radioactively contaminated facilities. Appendix $\mathrm{C}$ provides additional details regarding DOE-EM's real property investments at the site.

- $\quad$ NR directly funds maintenance and operations of NRF as discussed in Appendix C. NR is also directly contributing to the replacement Remote-Handled LLW Disposal Facility proposed to replace the one at RWMC.

\subsubsection{INL Strategic Investments}

INL Strategic Investments support institutional projects, both technical and support facilities and infrastructure, as required to advance the INL mission. This plan assumes an annual strategic investment of approximately $\$ 10$ million. In the next 3 to 5 years, these funds will go primarily to maintaining and modernizing institutional infrastructure that supports mission-critical and supporting capabilities such as utility enhancements (e.g., sewer, power, roads, and communication). The real property investments identified in Table B-1 (Institutional General Plant Projects [IGPPs]) are supported through INL strategic investments. INL strategic investments also support sustainability, as affordable.

\subsubsection{Alternatively Funded Investments}

Alternatively Funded Investments are the primary method to fund sustainability and efficiency projects, and savings are reinvested into new efficiency projects. This funding resource is utilized based on strict guidelines to ensure that the method is the most advantageous to the government in terms of cost savings and return on investment. Appendix D provides additional details on proposed and active alternatively funded projects underway at INL. 


\section{CHANGES FROM FISCAL YEAR 2013 TEN-YEAR SITE PLAN}

Two major changes have been made to the TYSP since the FY 2013 publication:

- This TYSP focuses on how INL will manage and sustain its real property assets to meet DOE mission needs within the current budgetary constraints and out-year fiscal projections

- To reflect the emphasis on real property, capital equipment investments are no longer included in TYSP investment data.

These changes resulted from DOE-NE guidance and direction received in discussions with DOE-NE.

DOE has issued a strategy in response to the Blue Ribbon Commission recommendations (DOE 2013). As specific implementation plans mature based on DOE's strategies, additional real property needs may be identified in subsequent revisions to this plan. 


\section{REFERENCES}

DOE 2010, Nuclear Energy Research and Development Roadmap, Report to Congress, U.S. Department of Energy, April 2010.

DOE 2012a, DOE Strategic Sustainability Performance Plan, Report to The White House Council on Environmental Quality, Department of Energy, June 2012.

DOE 2012b, Used Nuclear Fuel Storage and Transportation Research, Development, and Demonstration Plan, FCRD-FCT-2012-000053, Rev. 0, U.S. Department of Energy, April 2012.

DOE 2013, Strategy for the Management and Disposal of Used Nuclear Fuel and High-Level Radioactive Waste, January 2013.

DOE-ID 2012, FY 2013 INL Site Sustainability Plan with the FY 2011 Annual Report, DOE/ID-11383, Rev. 4, Department of Energy Idaho Operations Office, December 2012.

DOE-NE 2009, "Facilities for the Future of Nuclear Energy Research: A Twenty-Year Outlook (Draft)," Department of Energy Office of Nuclear Energy, February 2009.

EO 13423, "Strengthening Federal Environmental, Energy, and Transportation Management," Executive Order, June 24, 2007.

EO 13514, "Federal Leadership in Environmental, Energy, and Economic Performance," Executive Order, October 5, 2009.

NAS 2008, "Review of DOE's Nuclear Energy Research and Development Program," Committee on Review of DOE's Nuclear Energy Research and Development Program, Board on Energy and Environmental Systems, Division on Engineering and Physical Sciences, National Research Council of the National Academies, 2008, page 7.

NIPP 2009, DHS National Infrastructure Protection Plan.

PL 110-140, “Energy Independence and Security Act of 2007,” Public Law, December 19, 2007.

State of Idaho 1995, "Settlement Agreement and Consent Order to fully resolve all issues in the actions Public Service Co. of Colorado v. Batt, No. CV 91-0035-S-EJL (D. Id.) and United States v. Batt, No. CV-91-0065-S-EJL (D. Id.)," Executed October 16, 1995. 


\section{APPENDIX A}
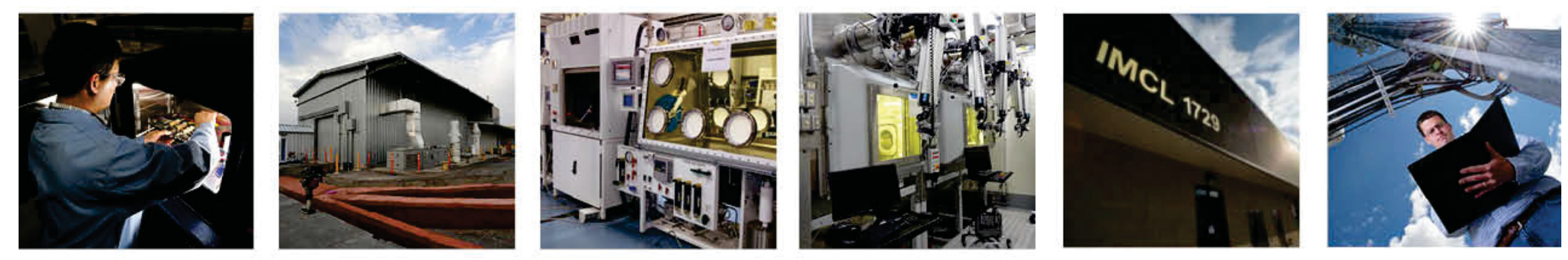

Real Property Asset Management 



\section{CONTENTS}

A-1. SUMMARY OF REAL PROPERTY

A-1.1 DOE-NE Owned and Operating Real Property Inventory

A-1.2 Asset Condition Index A-3

A-1.3 Asset Utilization Index A-4

A-2. REAL PROPERTY ASSET MANAGEMENT ....

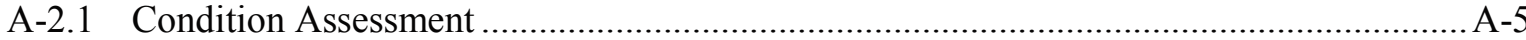

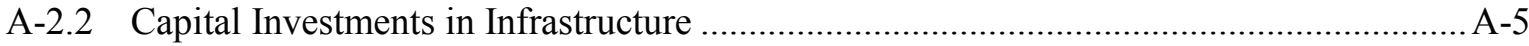

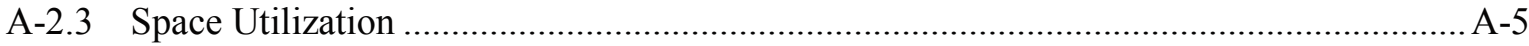

A-2.3.1 Space Planning Principles, Standards, and Criteria .....................................A-5

A-2.3.2 Space Utilization Surveys ..................................................................... A-6

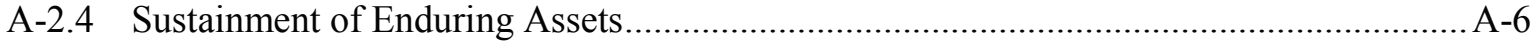

A-2.5 Disposition of Excess Real Property Assets ................................................................. A-6

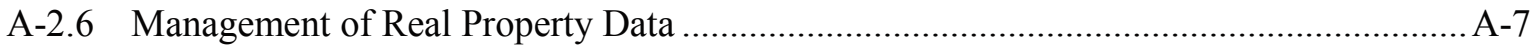

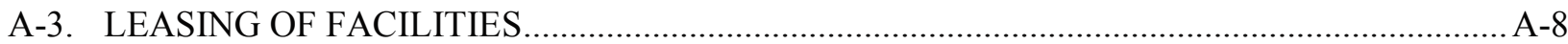

A-4. MANAGEMENT AND PRESERVATION OF HISTORIC REAL PROPERTY AT IDAHO NATIONAL LABORATORY

A-4.1 INL Historic Real Property

\section{FIGURES}

Figure A-1. Trends of deferred maintenance, total site replacement plant value, and asset condition index (Fiscal Year 2012 Federal Real Property Council snapshot)

Figure A-2. Asset condition index by mission dependency and property type.

Figure A-3. Experimental Breeder Reactor I. 


\section{TABLES}

Table A-1. Idaho National Laboratory mission critical real property inventory.

Table A-2. Summary of Department of Energy Office of Nuclear Energy owned and operating nonprogrammatic asset data

Table A-3. Idaho National Laboratory asset utilization index.......................................................... A-4

Table A-4. Summary of shutdown/excess property inventory ............................................................... A-7

Table A-5. Current Idaho National Laboratory Department of Energy Office of Nuclear Energy leased building information.

Table A-6. Planned Idaho National Laboratory Department of Energy Office of Nuclear Energy leased building information. 


\section{Appendix A \\ Real Property Asset Management}

While remaining focused on the vision established for INL by DOE, INL is realigning its priorities for real property asset management to focus on sustaining, fully utilizing, and obtaining the most value of existing assets to meet DOE-NE mission requirements.

To this end, INL is continuing the following efforts:

- Establish a solid baseline of real property asset condition and sustainment requirements

- Identify the risk associated with these requirements

- Prioritize sustainment activities

- Take action to mitigate the risk of those activities that cannot be accomplished due to resource limitations.

Specific multi-year asset management plans are being developed for significant asset groups (e.g., roads, roofs, etc.) to document sustainment and recapitalization requirements as a basis for future investment decisions and planning.

INL has also started accelerating efforts to improve utilization at REC by consolidating work and staff from minor leased buildings into DOE-owned and leased buildings. Investment in demolition of excess buildings to improve utilization at the INL Site, particularly at CFA, is low priority for funding allocation due to the relatively low risk associated with retaining these excess buildings in the inventory.

The historical trends of DM, RPV, and ACI are illustrated in the graphs in Figure A-1.

Deferred Maintenance (DM \$M)

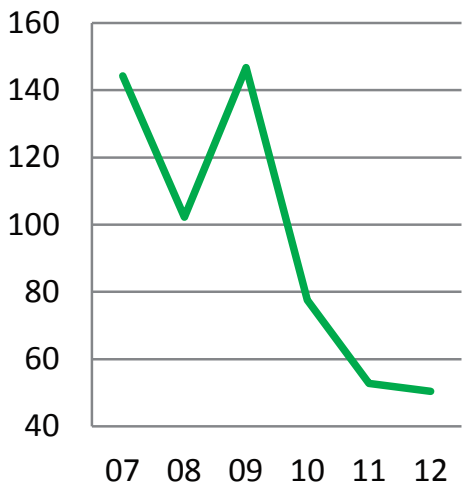

Total Site Replacement Plant Value (RPV \$B)

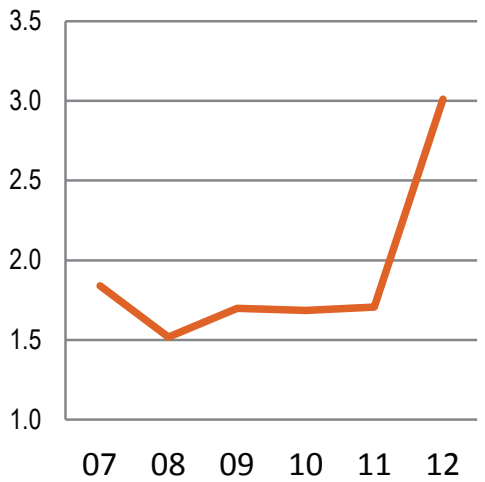

Asset Condition Index $(\mathrm{ACl})$

Control Range $=1.000$ to 0.950 )

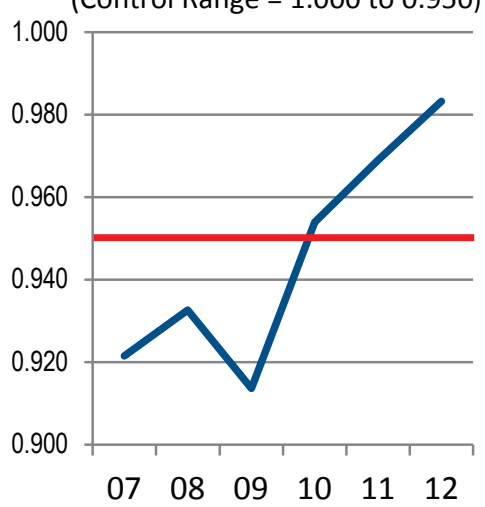

Figure A-1. Trends of deferred maintenance, total site replacement plant value, and asset condition index (Fiscal Year 2012 Federal Real Property Council snapshot). 


\section{A-1. SUMMARY OF REAL PROPERTY}

\section{A-1.1 DOE-NE Owned and Operating Real Property Inventory}

DOE-NE manages 485 nonprogrammatic ${ }^{\mathrm{a}}$ owned and operating real property assets. These assets have an estimated RPV of $\$ 2,849$ million and include 285 owned and operating buildings and real property trailers totaling 2.3 million $\mathrm{ft}^{2}$. The remaining 200 owned and operating assets are $\mathrm{OSFs}^{\mathrm{b}}$ that support these buildings.

DOE-NE real property inventory also includes three "programmatic" real property assets that have a total FIMS RPV of $\$ 1,397$ million. These three assets fall into the 3000-series FIMS OSF usage code category and include ATR, its cooling tower (TRA-771), and the TREAT reactor (MFC-726).

INL DOE-NE real property inventory includes the $27 \mathrm{MC}$ buildings, OSFs, and land assets listed in Table A-1. MC assets are defined as those that conduct primary missions of the site with defined, quantifiable output. All assets chosen have direct links to program sponsors, DOE-NE Roadmap (DOE 2010) R\&D objectives, or are part of other external commitments. They are unique and enable DOE-NE to make progress toward R\&D objectives and its various program missions.

Table A-1. Idaho National Laboratory mission critical real property inventory.

\begin{tabular}{|l|l|}
\hline \multicolumn{1}{|c|}{ FIMS Property ID } & \multicolumn{1}{c|}{ Property Name } \\
\hline ATR REACTOR (OSF) & ATR \\
\hline IF-603 & IRC Laboratory Building \\
\hline IF-605 & Energy Storage Technology Laboratory \\
\hline IF-638 & IRC Physics Laboratory \\
\hline IF-657 & INL Engineering Demonstration Facility \\
\hline IF-683 & RESL \\
\hline MFC-1702 & RCL \\
\hline MFC-1729 & IMCL \\
\hline MFC-704 & FMF \\
\hline MFC-704A & FMF Compressor Building \\
\hline MFC-709 & Safety Equipment Building \\
\hline MFC-752 & AL and Office Building \\
\hline MFC-765 & FCF \\
\hline MFC-774 & EML \\
\hline MFC-785 & HFEF \\
\hline MFC-787 & FASB \\
\hline MFC-792 & SSPSF Control Room \\
\hline MFC-792A & SSPSF Annex \\
\hline
\end{tabular}

a. Nonprogrammatic real property assets exclude assets with a FIMS usage code in the 3000-series of OSFs. At the INL, 3000 series OSFs include ATR, its cooling tower, and the TREAT reactor.

b. OSFs include any fixed real property improvements to land that are not classified as a building (e.g., bridges, towers, roads, and fences). They also include site utility systems used to generate or distribute any services such as heat, electricity, sewage, gas, and water. 
Table A-1. (continued).

\begin{tabular}{|l|l|}
\hline \multicolumn{1}{|c|}{ FIMS Property ID } & \multicolumn{1}{c|}{ Property Name } \\
\hline TAN-629 & SMC Assembly Building \\
\hline TAN-679 & Manufacturing and Assembly Building \\
\hline TAN-679A & Manufacturing and Assembly Annex \\
\hline TRA-670 & ATR Reactor Building \\
\hline TRA-770 & ATR Vent Stack \\
\hline TRA-771 a & ATR Cooling Tower \\
\hline IF-LAND-02a & DOE Owned IRC Land \\
\hline S-LAND-01a & Withdrawn from Public Use INL Site Land \\
\hline S-LAND-02a & DOE Owned INL Site Land \\
\hline $\begin{array}{l}\text { a. The ACl is not applicable to land or FIMS 3000 series OSFs. Therefore, these OSFs are not included in the ACl } \\
\text { discussion in Section A-1.2. FIMS 3000-series OSFs at INL are the ATR, its cooling tower, and the TREAT. }\end{array}$ \\
\hline
\end{tabular}

\section{A-1.2 Asset Condition Index}

The ACI for DOE-NE assets continues to improve due to investments in maintenance and continued improvement in the quality of FIMS RPV and DM data.

Table A-2 breaks down the DOE-NE building square feet, DM, and RPV for owned and operating assets ${ }^{\mathrm{c}}$ in each of the three mission dependency categories. Table A-2 also shows that the average ACI of INL DOE-NE real property exceeds the ACI target in each FIMS mission dependent (MD) category. Additionally, the ACI for each of the 22 DOE-NE MC assets ${ }^{\mathrm{d}}$ exceeds the 0.970 target.

Table A-2. Summary of Department of Energy Office of Nuclear Energy owned and operating nonprogrammatic asset data.

\begin{tabular}{|c|c|c|c|c|c|c|}
\hline $\begin{array}{c}\text { FIMS Mission } \\
\text { Dependency Category }\end{array}$ & $\begin{array}{l}\text { Number of } \\
\text { Assets }^{\mathrm{a}}\end{array}$ & $\begin{array}{l}\text { DM } \\
\text { (\$M) }\end{array}$ & $\begin{array}{l}\text { RPVa } \\
(\$ M)\end{array}$ & $\begin{array}{l}\text { Gross Square Feet } \\
\text { (GSF) } \\
\left.\text { (million } \mathrm{ft}^{2}\right)\end{array}$ & $\mathrm{ACl}$ & Target ${ }^{b}$ \\
\hline Mission Critical & 22 & 3.5 & 1,634 & 0.8 & 0.998 & 0.970 \\
\hline Mission Dependent & 309 & 39.2 & 1,089 & 1.1 & 0.964 & 0.925 \\
\hline Not Mission Dependent & 154 & 7.7 & 127 & 0.4 & 0.939 & 0.900 \\
\hline TOTAL & 485 & 50.4 & 2,849 & 2.3 & 0.982 & 0.950 \\
\hline \multicolumn{7}{|c|}{$\begin{array}{l}\text { a. Reduction of the number of assets and RPV from } 2012 \text { are the result of excluding leased assets from this data and implementing new FIMS } \\
\text { RPV site factors (September 2012). } \\
\text { b. The ACI targets are from the DOE Three-Year Rolling Timeline, FY } 2013 \text { Update, March 2013. All targets were lowered from } 2012 \text { levels } \\
\text { with the issue of the FY } 2013 \text { update. }\end{array}$} \\
\hline
\end{tabular}

c. Operating assets are those with a FIMS status code of 1, 2, or 6.

d. The ACI is not applicable to land or FIMS 3000 series OSFs. Therefore, these OSFs are not included in the ACI discussion above. FIMS 3000-series OSFs at INL are the ATR, its cooling tower, and the TREAT. 
Figure A-2 presents additional detail concerning the ACI for owned and operating DOE-NE assets by property type (e.g., building, trailer, or OSF). It provides a breakdown of the ACI target, the average ACI for all assets, the ACI for buildings and trailers, and the ACI for OSFs in each mission dependency category.

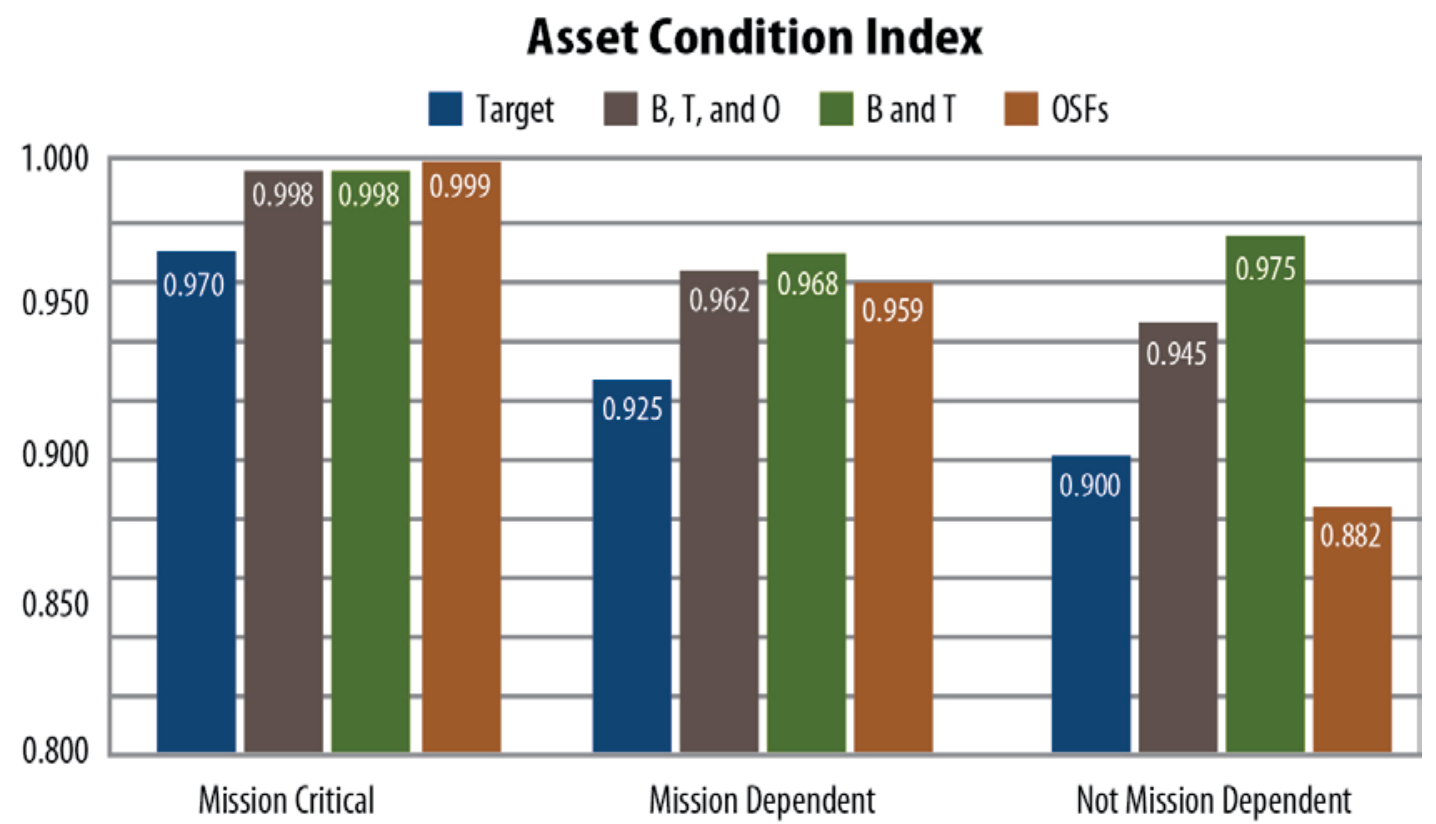

Figure A-2. Asset condition index by mission dependency and property type.

\section{A-1.3 Asset Utilization Index}

The asset utilization index (AUI) for INL DOE-NE-owned assets is summarized in Table A-3. Overall, the INL AUI decreased by $2 \%$ when compared to FY 2012. The AUI for MFC and the ATR Complex followed the overall trend as well, dropping $3 \%$ and $1.4 \%$, respectively.

Table A-3. Idaho National Laboratory asset utilization index.

\begin{tabular}{|c|c|c|c|}
\hline Site Area & $\begin{array}{l}\text { Owned Facilities } \\
\text { (GSF) }^{\mathrm{a}}\end{array}$ & AUlb & Rating \\
\hline MFC & 632,017 & $92.2 \%$ & Adequate \\
\hline ATR Complex & 393,216 & $96.5 \%$ & Good \\
\hline REC & 297,296 & $95.0 \%$ & Good \\
\hline Balance of INL & $1,094,641$ & $85.7 \%$ & Fair \\
\hline All INL Facilities & $2,417,170$ & $90.3 \%$ & Adequate \\
\hline \multicolumn{4}{|c|}{ 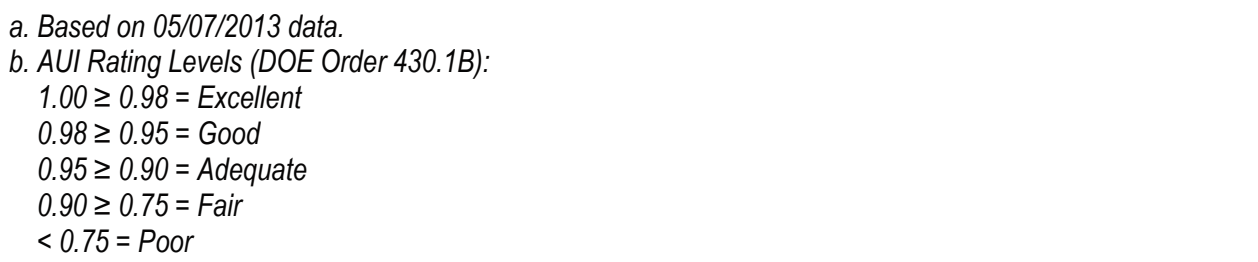 } \\
\hline
\end{tabular}


The reduced AUI is mostly the result of recent (2012 and 2013) improvements in utilization tracking and reporting. These improvements more accurately account for the unutilized space in shutdown and operational standby buildings. AUI reductions are also a result of FY 2012 and FY 2013 workforce restructuring.

\section{A-2. REAL PROPERTY ASSET MANAGEMENT}

The key elements of the INL real property asset management program include condition assessment, capital investment in new and revitalized infrastructure, space utilization, sustainment, disposition of excess real property, and management of real property data. Each of these key elements is discussed in greater detail in the following subsections.

\section{A-2.1 Condition Assessment}

The INL Condition Assessment Program fulfills the requirements of DOE Order 430.1B, Real Property Asset Management. INL employs facility managers, engineers, and third-party contractors to inspect DOE-NE real property assets at least every 5 years. Primary roads are inspected under contract with the Idaho Transportation Department using modern, vehicle-mounted inspection equipment. Bridge inspections are performed under subcontract to a qualified bridge inspector. Roof assets are inspected by the NNSA Roof Asset Management Program (RAMP) contractor.

INL bases its DM backlog on the deficiencies identified during these condition assessment surveys. Condition information from facility professionals, which is based on feedback from building occupants and their own operating and maintenance experience, contributes to identification of DM. These deficiencies are recorded in the DOE Condition Assessment Information System (CAIS) database and submitted for execution to the INL computerized maintenance management system. The CAIS data are the source of DM uploaded to FIMS during the annual FIMS update cycle.

\section{A-2.2 Capital Investments in Infrastructure}

Ongoing capital investment in new construction, expansion, and recapitalization is providing needed R\&D capability, space, and support infrastructure capacity and reliability.

\section{A-2.3 Space Utilization}

\section{A-2.3.1 Space Planning Principles, Standards, and Criteria}

The INL goal is to ensure employees are provided a modern, collaborative, and sustainable work environment that is flexible by design and can be configured to meet specific program and/or project needs without major renovation and investment. INL has updated its office standards and provided a variety of office and workspace types and sizes based on job code and function, privacy, and work style needs.

Consistent with industry practices, these types of spaces are trending to a smaller individual footprint within well laid-out neighborhoods that provide open, multiuse areas and invite groups together for team-based work.

These spaces include the traditional conference rooms plus huddle areas that allow small groups to find convenient private locations for impromptu meetings and open areas that include space for casual meetings, shared storage, equipment areas, and break rooms. This open office environment encourages team collaboration supporting today's researchers and staff members' work styles based on modern technology options. 
The combination of the assigned office space, office support areas, and collaboration space results in an average total workspace allocation of $200 \mathrm{ft}^{2}$ per person. This standard is being applied to new buildings and modernized space, as funding allows. Existing buildings have a space allocation goal of $230 \mathrm{ft}^{2}$ per occupant. Over the next few years, efforts will be taken to reestablish conference rooms and collaboration areas that were modified to office space during a time when INL was having difficulty keeping up with office space demands. Once completed, a more accurate accounting of facility utilization can be tracked. Until that time, fluctuations will be seen due to restructuring, consolidation, and collocation effort.

\section{A-2.3.2 Space Utilization Surveys}

In FY 2011, INL conducted a utilization survey of office and laboratory space to develop laboratory and office standards. The standards enable INL to use existing space more effectively and plan efficient new facilities.

Currently, the condition of the offices varies. The large office complexes are generally in average condition, while some of the smaller facilities on the INL Site are in less desirable condition. Individual space utilization, when comparing actual space assignments to the space standards, is below the targeted utilization in all buildings.

\section{A-2.4 Sustainment of Enduring Assets}

INL maintenance budgets are expected to remain flat or decrease over the 5-year sustainment planning horizon. Therefore, the INL sustainment strategy will continue to focus on corrective maintenance and cost-effective preventive maintenance and predictive monitoring that is based on the principles of reliability centered maintenance. Refer to Table A-2 and Section A-1.2 for a discussion of the ACI for DOE-NE INL real property assets.

INL has used the NNSA RAMP for roof condition assessments, condition data management, and planned roof repair and replacement activities since FY 2010. Use of the RAMP has resulted in the replacement of $105,687 \mathrm{ft}^{2}$ of roof area with "Cool Roof" technology. INL installed $86,000 \mathrm{ft}^{2}$ of new cool roof area as part of recent new construction, including the $67,000-\mathrm{ft}^{2}$ roof for the new REL that was completed in October 2013. Additionally, completion of REL in the fall of 2013 will add another $44,000 \mathrm{ft}^{2}$ of new cool roof area.

\section{A-2.5 Disposition of Excess Real Property Assets}

INL has demolished $369,512 \mathrm{ft}^{2}$ of excess buildings since inception of the BEA INL contract in February 2005.

INL real property inventory includes 53 excess real property assets ${ }^{\mathrm{e}}$ that are managed in a safe and stable condition until funding is allocated to accomplish planning and disposition. Table A-4 provides a summary of this inventory.

\footnotetext{
e. Excess assets include those with a shutdown related FIMS status codes for buildings, trailers, and OSFs (FIMS status codes 3 ,
} $4,5,11$, and 12). 
Table A-4. Summary of shutdown/excess property inventory.

\begin{tabular}{|c|c|c|}
\hline Excess Property Type & Inventory & GSF \\
\hline \multicolumn{3}{|l|}{ Buildings } \\
\hline National Register Eligible (NRE) & 11 & 119,784 \\
\hline Non Historic & 3 & 13,329 \\
\hline \multicolumn{3}{|l|}{ OSFs } \\
\hline NRE & 1 & N/A \\
\hline Non Historic & 38 & $\mathrm{~N} / \mathrm{A}$ \\
\hline Total & 53 & 133,113 \\
\hline
\end{tabular}

The INL excess building disposition plan was developed to meet the following needs:

- Reduce the cost, hazards, risk of continued asset deterioration, and visual impact associated with maintaining an excess asset in the inventory for an extended period after the asset has been declared to be excess

- Improve the work environment and operational efficiency as part of campus planning activities

- Clear land area to provide for expansion or construction of new buildings

- "Bank" demolished square footage to offset expansion or construction of new square footage.

A proposed dispositioning plan for excess INL buildings is included in Appendix B, Table B-4. The actual investment and disposition square-foot profile will depend on the amount of funding that is ultimately allocated to this effort.

\section{A-2.6 Management of Real Property Data}

INL captures real property data in the DOE FIMS database. Efforts to improve the quality of the FIMS data have been documented in the last three TYSPs. Recent activities include the following:

- Calculating FIMS RPVs for MC and MD buildings and OSFs that are not, or not adequately, modeled by FIMS RPV models (February 2012)

- Implementing the FIMS conventional facility indicator $(\mathrm{CFI})^{\mathrm{f}}$ to improve the validity of the Maintenance Investment Index (MII; February 2012)

- Developing a comprehensive FIMS data quality assurance plan (March 2012)

- Updating the FIMS RPV site factors.

f. The CFI is a FIMS approved process for applying a percentage factor, the CFI, to the asset RPV prior to the RPV being used in calculation of the site Maintenance Investment Index (MII; target is 2\% to 4\% of site RPV). The factor reflects the fraction of the asset RPV that is considered "conventional" and is used to exclude those assets, or the portions of asset, that are unique programmatic assets and therefore not within the basis of the MII measure. 
Implementation of the new RPVs was completed in February 2012. Part of this implementation included applying a FIMS CFI. These investments, in the improvement of RPVs and implementation of the CFI, have resulted in a significant improvement in the accuracy of the ACI and the MII (target is $2 \%$ to $4 \%$ of site RPV) for DOE-NE assets at INL. The MII for FY 2012 is $2.34 \%$ of the site RPV.

\section{A-3. LEASING OF FACILITIES}

INL leases 24 buildings (Table A-5) totaling 823,189 GSF with an annual rent of $\$ 7.5$ million. All but one of these buildings (the Boise, Idaho Outreach Office) are located at REC in Idaho Falls, Idaho. The lease rates for the two primary INL office buildings in Idaho Falls (Willow Creek Building [WCB; IF616] and EROB [IF-654]) are extremely favorable. These two buildings provide 500,000 $\mathrm{ft}^{2}$ at an average rate of $\$ 5.25 / \mathrm{ft}^{2}$ annually. Although INL intends to occupy government-owned buildings whenever possible, facility leasing will continue to be an important and cost-effective component in INL's facility management and campus planning strategy. Planned leased building information is provided in Table A-6.

This strategy, which is centralized around INL's gateway of core $R \& D$, leases general purpose office and laboratory buildings when it is in the best interest of the government and the INL mission. Leased buildings will be obtained that provide the best value to government; that maximize employee comfort, health, and productivity; and minimize operating and utility costs. Certification to the Leadership in Energy and Environmental Design (LEED) Gold for New Construction is the INL standard for design and construction of new building leases or build-to-suit leases. New leases on existing buildings will include provisions to evaluate the facility prior to occupancy for energy efficiency and the ability of the building systems to provide the appropriate indoor environmental quality. Cost-effective updates are incorporated into new/renegotiated leases for existing buildings to maximize energy efficiency and employee productivity by incorporating the guiding principles for HPSBs.

When leases on existing buildings are renewed, negotiations will include energy updates to maximize energy efficiency and employee productivity by incorporating the EO 13423, "Guiding Principles." For leases intended to be very short-term temporary occupancies, the buildings will be evaluated and updated on a case-by-case basis, with a preference for a facility that demonstrates better energy efficiency and indoor environmental quality. This allows enhancement of R\&D capabilities and, at the same time, provides the most cost-effective alternative to construction of new DOE-owned buildings as a tool to optimize the facility inventory. Additionally, this strategy provides the ability to consolidate and collocate into a more enduring centralized campus area, which allows for termination of outlying and substandard leased facilities.

There are a few unique R\&D activities occurring at leased facilities located a significant distance from the REC core campus area. The buildings that house these activities will need to be replicated through new leases or acquisitions. Relocating these activities to the newly leased REL or ESL is not appropriate primarily due to laboratory size, floor loading, adjacency of other nonrelated activities, vibration, and several other factors. These new leases or acquisitions will follow the guiding principles of EO 13423.

INL took occupancy of ESL, a new long-term contractor-leased laboratory building, in April 2013. INL has also entered into agreement for construction of another long-term leased building, REL, on University Boulevard. REL will be ready for occupancy in FY 2014. These two buildings will support consolidation of staff and equipment and enhance the research capability of the REC campus. Additionally, the LEED Gold certification will contribute to achieving DOE targets for HPSBs. 


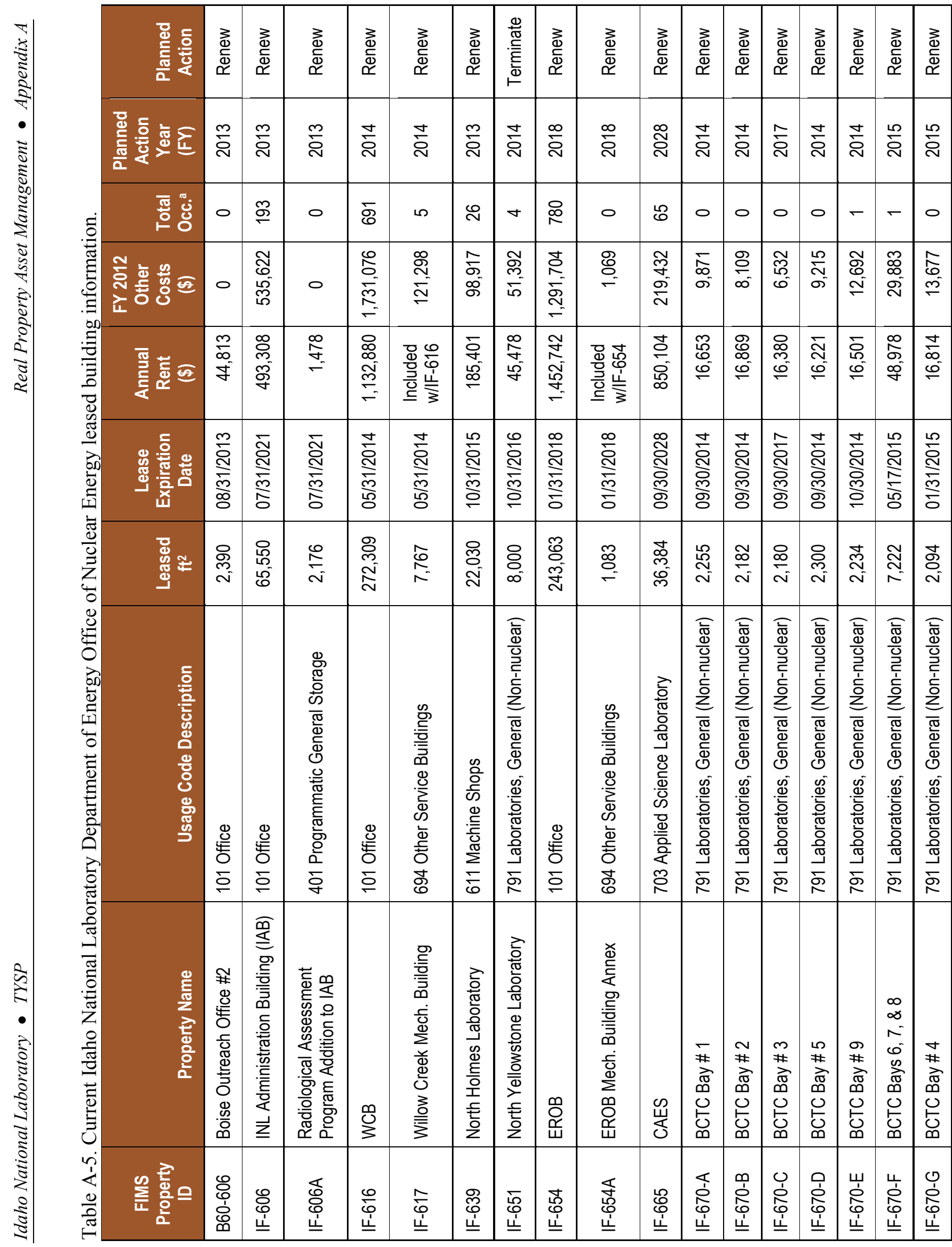



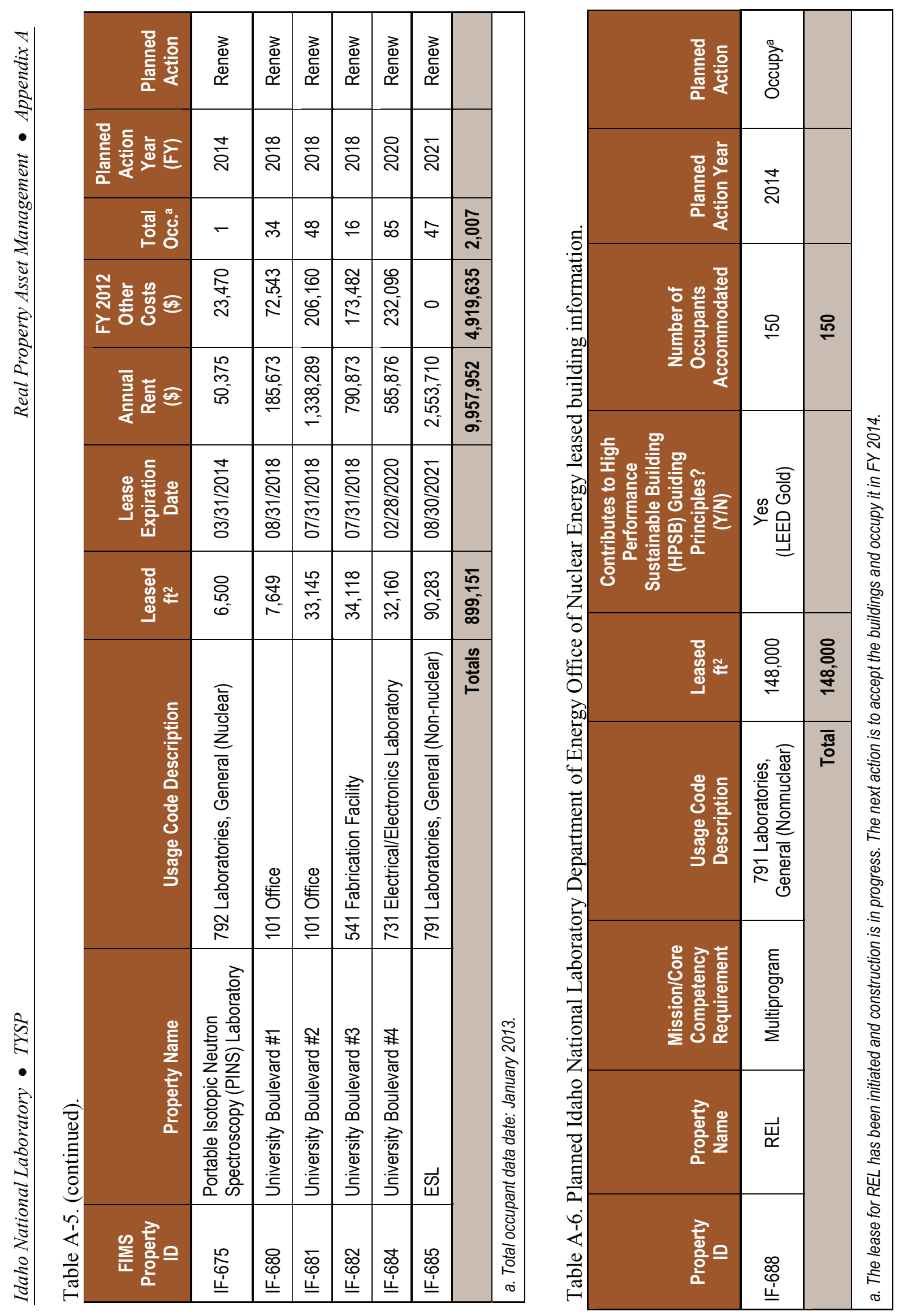
Populating the new ESL and REL will make space available at IRC facilities and enable relocating staff and equipment from the North Boulevard Annex (IF-613) and North Yellowstone Laboratory (IF-651) to IRC. The underutilized International Way Building (IF-674) was vacated in the second quarter of FY 2012 and consolidated into the University Boulevard \#4 Building (IF-684) and Modular Office Trailer (CF-1610). Relocation out of the INL Research Library (IF-618) into the Radiological Environmental Sciences Office Building (IF-601) in February 2013 allowed termination of the library lease and further reduced leased facilities.

Vacating the remaining outlying facilities, the PINS Laboratory (IF-675) and North Holmes Laboratory (IF-639), will require acquisition of new facilities to consolidate them into the REC campus. As stated above, available space in ESL and REL is not appropriate for the activities performed in the PINS and North Holmes laboratories.

On the INL Site, leasing is practiced only as an option for temporary structures (e.g., construction and short-term office trailers). Capital investment (General Plant Project [GPP] and Institutional General Plant Project [IGPP]) is preferred for satisfying long-term space needs.

\section{A-4. MANAGEMENT AND PRESERVATION OF HISTORIC REAL PROPERTY AT IDAHO NATIONAL LABORATORY}

Cultural resources are found within INL boundaries that represent over 13,000 years of human land use. They include an estimated 70,000 prehistoric archaeological sites dating from the early prehistoric period, thousands of historic archaeological sites dating back to the early $1800 \mathrm{~s}$, and 101 historic real property buildings and OSFs related to World War II and the early pioneering era of nuclear energy in the United States.

The management of INL cultural resources is driven and guided by various federal laws, regulations, executive orders, DOE directives, supplementary State of Idaho statutes, and an Agreement-in-Principle between DOE-ID and the Shoshone-Bannock Tribes. These requirements have been tailored to the unique needs of INL through the INL Cultural Resource Management Plan (DOE-ID 2013), as legitimized through a Programmatic Agreement between DOE-ID, the Idaho State Historic Preservation Office, and the Advisory Council on Historic Preservation.

\section{A-4.1 INL Historic Real Property}

EBR-I (Figure A-3) is a national historic landmark that is open to the public for self-guided tours during the summer months. FIMS assets associated with the reactor are building EBR-I-601 and the small guardhouse (EBR-I-602) - a National Register eligible DOE signature property.

Nine other National Register eligible INL real property assets have been classified as "DOE Signature Properties," a term coined by the Department of Energy Headquarters (DOE-HQ) that denotes the most historically significant properties across the complex and/or those that have tourism potential. These nine real property assets include the following:

- Four buildings (CF-606, -607, -613, and -632), two water pump houses (CF-642 and CF-651), and the concussion wall, gun emplacements, and gantry crane located near CF-633 that remain from the Arco Naval Proving Ground (NPG). The two pump houses are operating and are the primary source of potable and fire suppression water to CFA. The remaining NPG related assets are not operating and in a FIMS status of shutdown pending D\&D.

- Hanger (TAN-629), formerly used for development of the nuclear powered airplane, now used by SMC. 


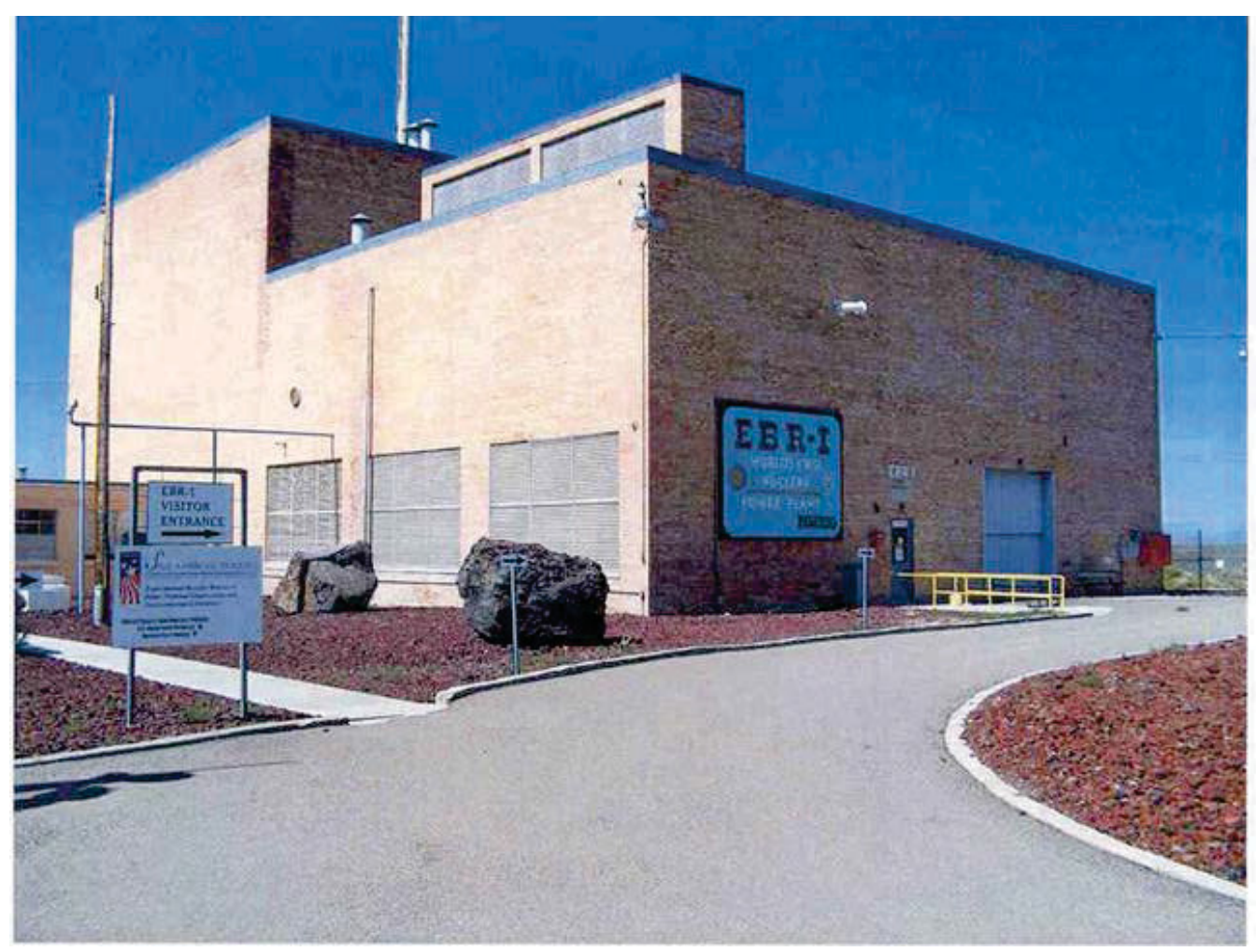

Figure A-3. Experimental Breeder Reactor I.

\section{A-5. REFERENCES}

DOE, 2010, Nuclear Energy Research and Development Roadmap, Report to Congress, U.S. Department of Energy, April 2010.

DOE Order 430.1B, Real Property Asset Management, Chg. 2, U.S. Department of Energy, September 2003.

DOE-ID, 2013, INL Cultural Resource Management Plan, DOE/ID-10997, Rev. 5, Department of Energy Idaho Operations Office, February 2013.

EO 13423, "Strengthening Federal Environmental, Energy, and Transportation Management," Executive Order, June 24, 2007. 


\section{APPENDIX B}
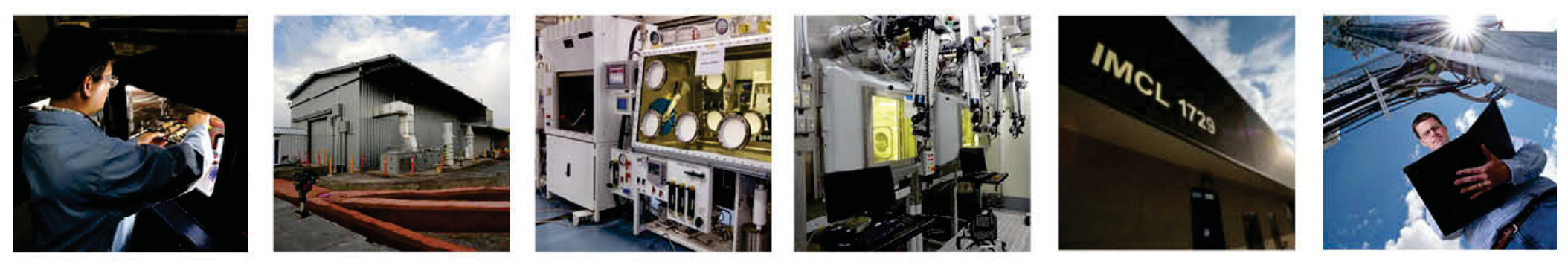

Prioritized Resource Needs 



\section{CONTENTS}

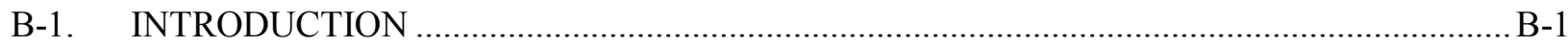

B-2. INSTITUTIONAL GENERAL PLANT PROJECTS..................................................................

B-3. PROGRAMMATIC GENERAL PLANT PROJECTS …...................................................... B-1

B-4. LINE-ITEM CONSTRUCTION PROJECTS ….................................................................. B-1

B-5. OTHER INFRASTRUCTURE ACTIVITIES …...................................................................

\section{TABLES}

Table B-1. Institutional General Plant Projects (actual or planned budget total estimated cost $[\mathrm{TEC}]-\$ \mathrm{k})$.

Table B-2. Programmatic General Plant Projects (actual or planned Budget Authority [BA] TEC - \$k)

Table B-3. Line-item construction projects (actual or planned BA total project cost $[\mathrm{TPC}]-\$ \mathrm{~K})$

Table B-4. Other infrastructure activities (actual or planned budget TPC $-\$ K$ ). B-4 


\section{Appendix B \\ Prioritized Resource Needs}

\section{B-1. INTRODUCTION}

Achieving the 10-year infrastructure vision requires INL to align its infrastructure priorities with both its critical mission goals and a reasonably forecasted funding profile. INL has refined its planning for major capital improvements, both acquisitions and enhancements, by prioritizing its core capabilities and outlining an approach for capital improvements based on program strategies and recognition of current funding outlooks. Appendix B outlines the investments directed toward addressing the gaps identified in Table 5-1 of this TYSP.

\section{B-2. INSTITUTIONAL GENERAL PLANT PROJECTS}

Small, general-purpose construction efforts are primarily accomplished via INL's IGPP process. INL prioritizes qualifying infrastructure needs for this strategic investment at the executive leadership level and implements projects according to funding availability. If planned acquisitions lag behind identified need dates due to constrained strategic investments, INL actively seeks appropriate funding alternatives (i.e., program investment). IGPP plans are delineated in Table B-1.

\section{B-3. PROGRAMMATIC GENERAL PLANT PROJECTS}

INL identifies program-funded infrastructure projects through the annual program planning and budget formulation process. GPP infrastructure acquisition and recapitalization plans are listed in Table B-2. The table reflects the interval addressed by the laboratory's annual program planning process (FY 2013 FY 2019).

\section{B-4. LINE-ITEM CONSTRUCTION PROJECTS}

Congressional line-item funding is used to accomplish construction projects that have capital costs in excess of $\$ 10$ million. INL is currently executing one line-item construction project listed in Table B-3. One potential project is also listed.

\section{B-5. OTHER INFRASTRUCTURE ACTIVITIES}

Additional infrastructure activities necessary to support continued execution of mission objectives are presented in Table B-4. Three types of investments are captured in this table:

1. The ESL and REL leasehold improvements are funded with INL strategic investment funding

2. The expansion of the Space and Security Power Systems Facility will be funded by NASA

3. The remaining investment needs have undetermined sponsors and funding mechanisms. 


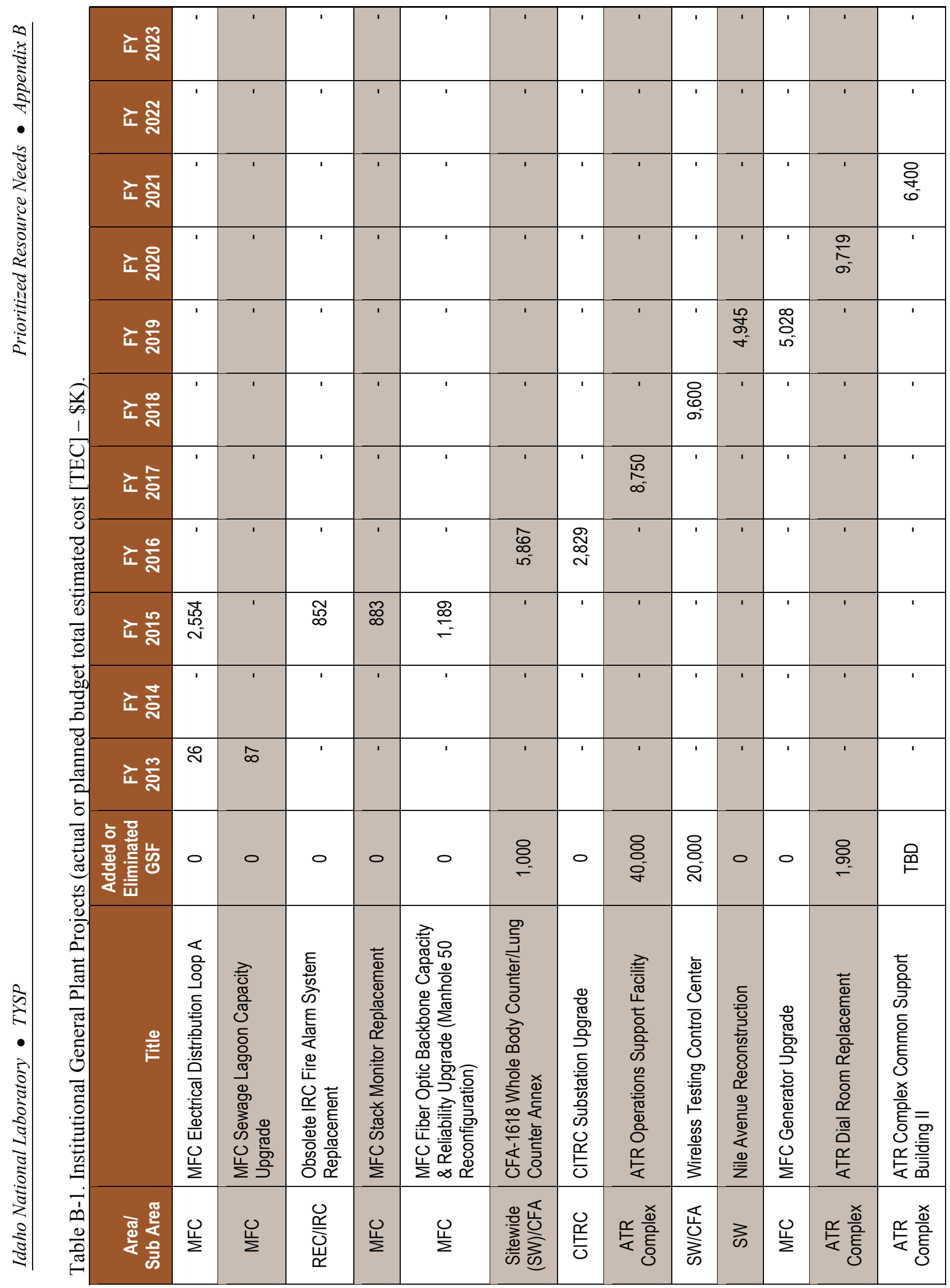




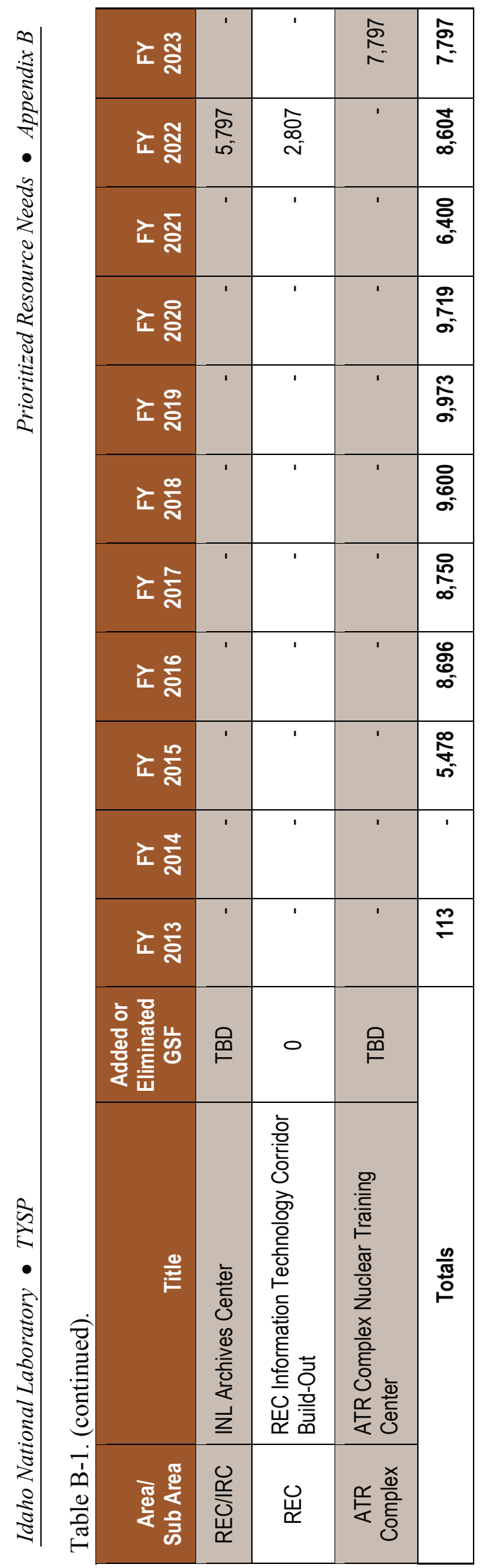

\begin{tabular}{|c|c|c|c|c|c|c|c|}
\hline 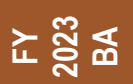 & & & & & & & \\
\hline 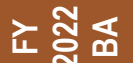 & & & & & & & \\
\hline خ文 & & & & & & & \\
\hline 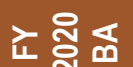 & & & & & & & \\
\hline 市送芯 & & & & & & $\begin{array}{l}\text { O্ } \\
\text { O্ } \\
\infty\end{array}$ & 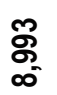 \\
\hline خ্் & & & & & $\begin{array}{l}\text { 유 } \\
\text { m } \\
\text { m. }\end{array}$ & & 怘 \\
\hline خ돓 & & & & 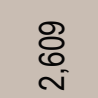 & & & : \\
\hline 乙্ণ & & ৪ & 足 & & & & 告 \\
\hline 는 올 & & & & & & & ' \\
\hline 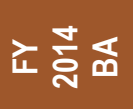 & & & & & & & ' \\
\hline 立离更 & $\stackrel{0}{0}$ & & & & & & $\stackrel{0}{\circ}$ \\
\hline 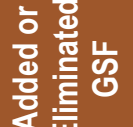 & 0 & 0 & ষ্ণ & 0 & 0 & $\begin{array}{l}8 \\
\text { బั }\end{array}$ & \\
\hline$\stackrel{0}{\underline{E}}$ & 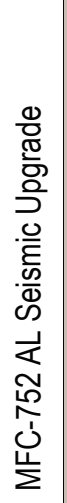 & 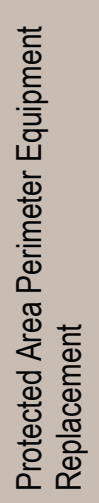 & 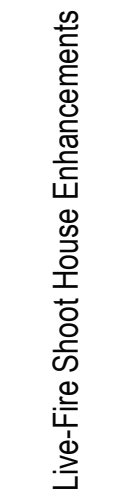 & 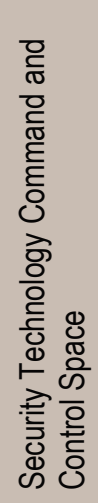 & 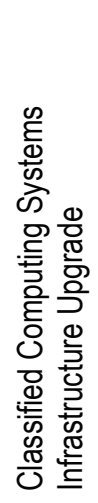 & 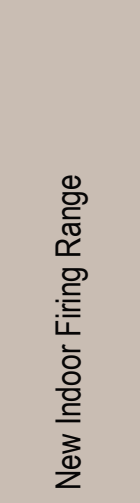 & $\frac{\frac{\infty}{0}}{\stackrel{5}{0}}$ \\
\hline$\frac{\mathbb{\$}}{\frac{1}{\alpha}}$ & $\stackrel{u}{亡}$ & के & 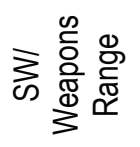 & 㞱 & 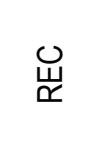 & 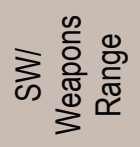 & \\
\hline 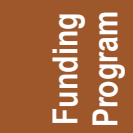 & 㞱 & ळ & $\begin{array}{l}\mathscr{D} \\
\infty\end{array}$ & మ & ஜ & ஜ & \\
\hline
\end{tabular}




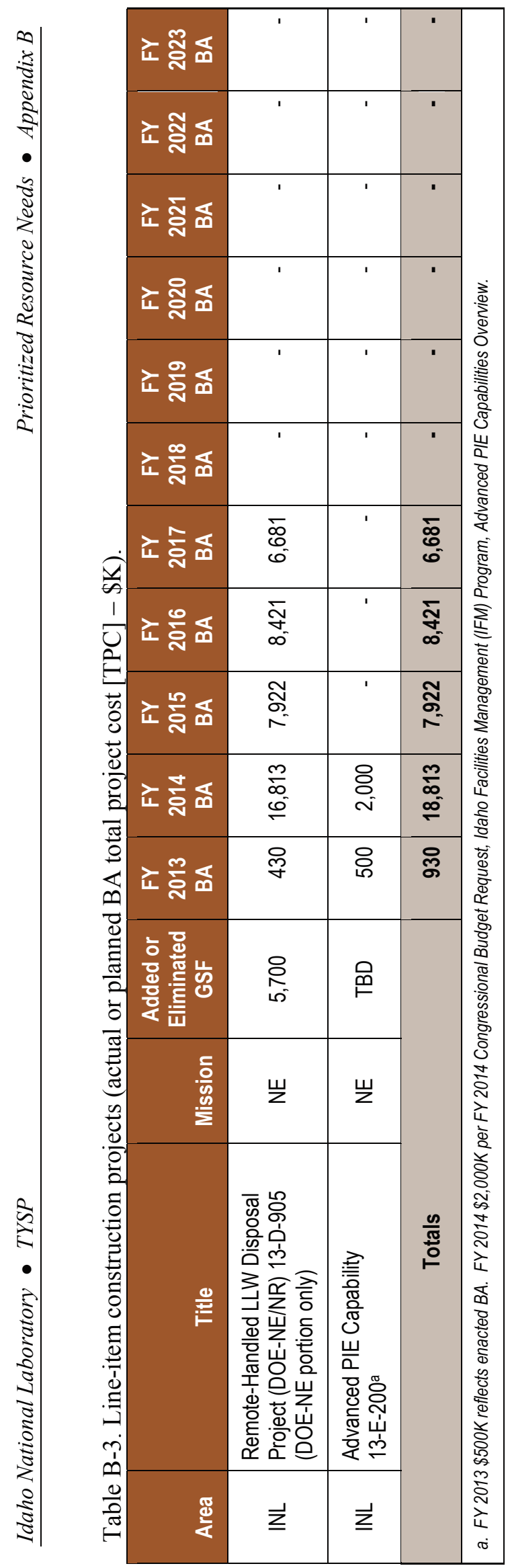

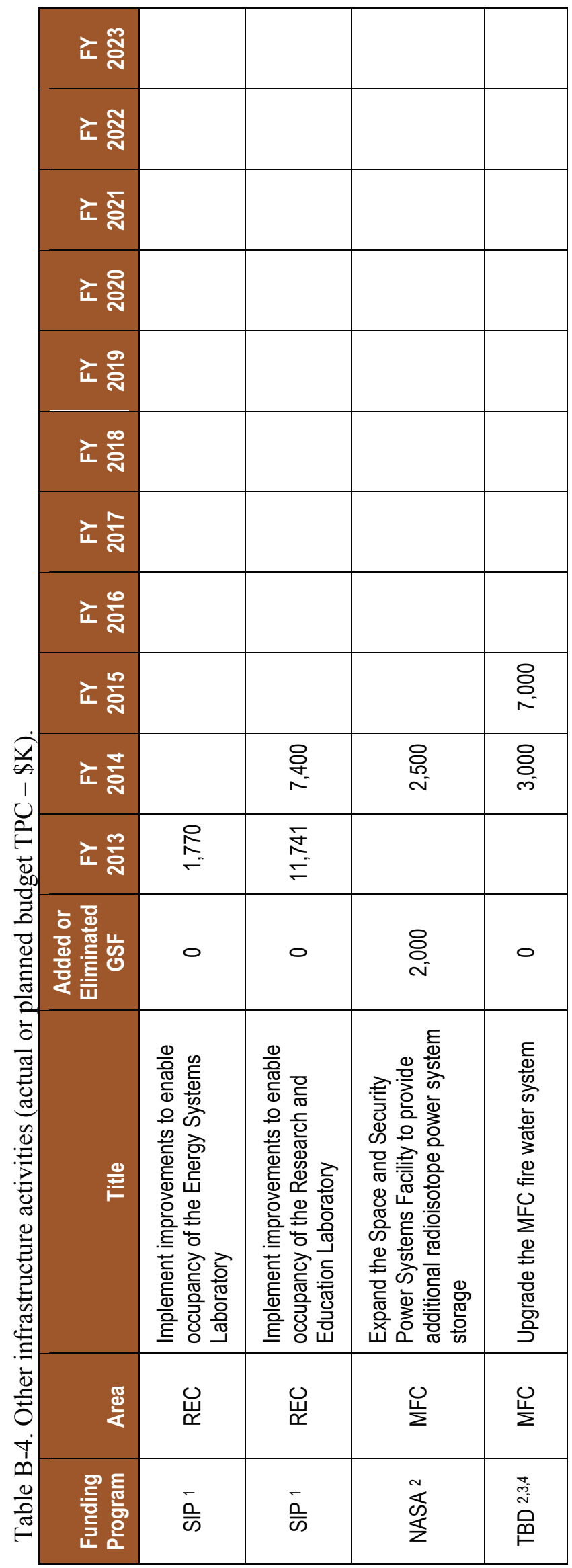




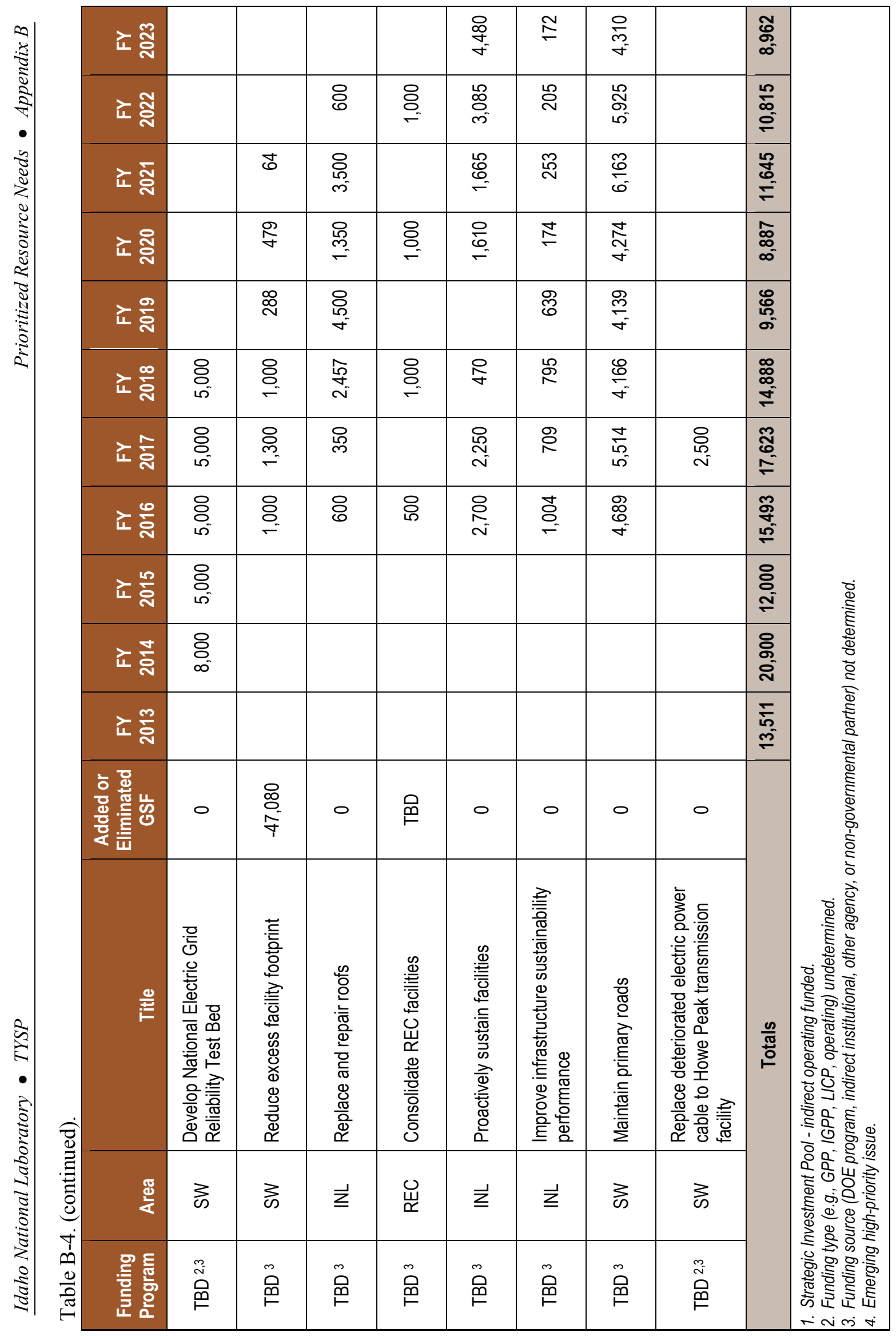




\section{APPENDIXC}
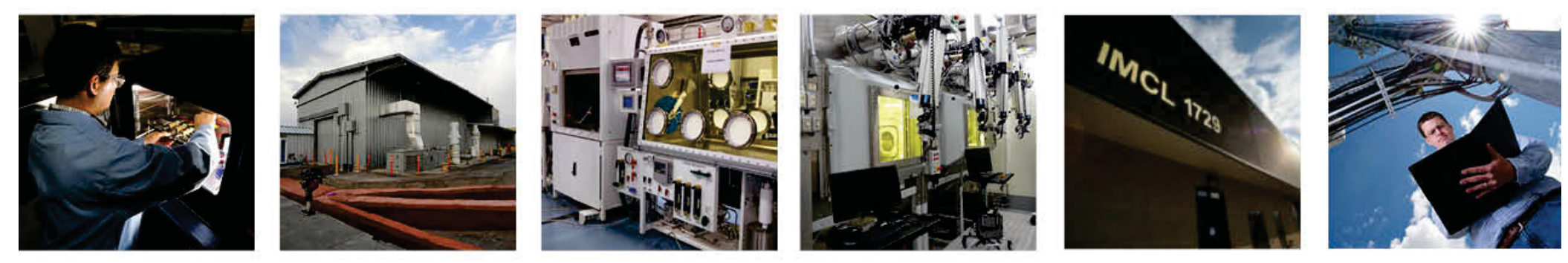

\section{Cognizant Secretarial Offices, Program Secretarial Offices, and Non-DOE Site Programs}





\section{CONTENTS}

\section{C-1. IDAHO CLEANUP PROJECT AND ADVANCED MIXED WASTE TREATMENT PROJECT OVERVIEW}

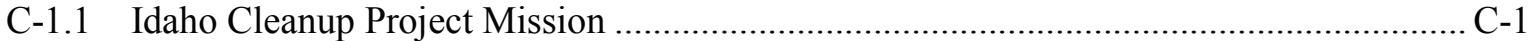

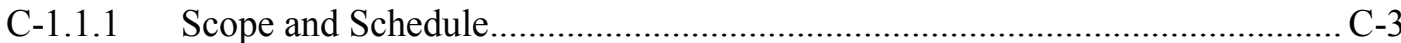

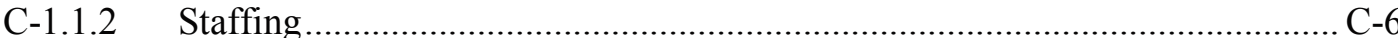

C-1.1.3 Facilities and Infrastructure Overview ....................................................... C-7

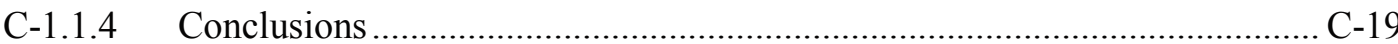

C-1.2 Advanced Mixed Waste Treatment Project Mission ...................................................... C-20

C-1.2.1 Advanced Mixed Waste Treatment Project Facility Status............................ C-21

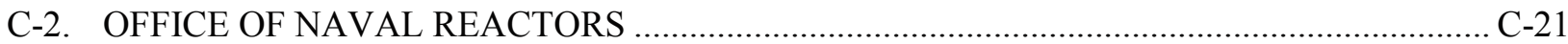

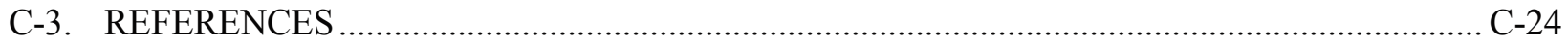

\section{FIGURES}

Figure C-1. Idaho Cleanup Project life-cycle schedule.

Figure C-2. Projected Idaho Cleanup Project staffing for full-time equivalents averaged over the fiscal year

Figure C-3. Fiscal Year 2012 Facility Information Management System Conditions of Department of Energy Office of Environmental Management buildings assigned to the Idaho Cleanup Project.

\section{TABLES}

Table C-1. Department of Energy Idaho Operations Office of Environmental Management profile (Fiscal Year 2013 to Fiscal Year 2024)

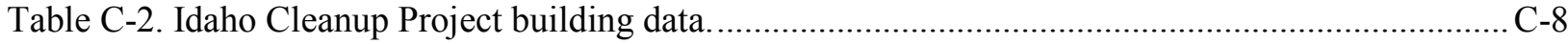

Table C-3. Idaho Cleanup Project proposed recapitalization projects.................................................. C-15

Table C-4. Idaho Cleanup Project building deactivation...................................................................... C-19

Table C-5. Advanced Mixed Waste Treatment Project proposed capitalization projects....................... C-22 


\section{APPENDIX C \\ COGNIZANT SECRETARIAL OFFICES, PROGRAM SECRETARIAL OFFICES, AND NON-DOE SITE PROGRAMS}

Under DOE Order 430.1B, Chg. 2, Real Property Asset Management, the landlord of a site has the responsibility to act as a host landlord for its resident Cognizant Secretarial Offices (CSOs) or Program Secretarial Offices (PSOs), including coordinating all CSO/Lead PSO programmatic needs and presenting a single coordinated TYSP, which includes any tenant-specific TYSPs. The site landlord also has the responsibility to ensure that the TYSP reflects infrastructure agreements between the Lead PSOs and CSOs, that projected programmatic needs and potential growth are analyzed and reviewed with the programs, and that their infrastructure support requirements are integrated into the planning process.

DOE-EM and Office of Naval Reactors are the two largest non-DOE-NE organizations at the INL Site. DOE-EM, which is a CSO, owns most facilities at INTEC and RWMC, and manages ICP and AMWTP. The Office of Naval Reactors owns NRF.

This appendix describes the facilities occupied, work performed, and recapitalization projects planned for implementation by DOE-EM. A brief overview of INL's support service interactions with the NRF is also provided.

\section{C-1. IDAHO CLEANUP PROJECT AND ADVANCED MIXED WASTE TREATMENT PROJECT OVERVIEW}

DOE-EM's cleanup mission at the INL Site is to safely accomplish as much of DOE-EM's cleanup mission as possible within available funding, while meeting regulatory requirements through the contract completion date.

\section{C-1.1 Idaho Cleanup Project Mission}

The DOE-ID INL mission is to develop and deliver cost-effective solutions to both fundamental and advanced challenges in nuclear energy (and other energy resources), national security, and environmental management. The DOE-ID cleanup mission for the INL Site is to complete the environmental cleanup in a safe, cost-effective manner, consistent with the DOE-EM objectives and regulatory agreements. The objectives include:

- Objective DOE-EM 1: Complete efforts to safely accelerate risk reduction, footprint reduction, and continued protection of the Snake River Aquifer

- Objective DOE-EM 2: Complete shipment of TRU waste offsite and meet commitments in the Idaho Settlement Agreement

- Objective DOE-EM 3: Identify innovative approaches to post-2012 work scope, such as calcine, spent fuel, D\&D, and institutional control

- Objective DOE-EM 4: Maintain federal baseline management and government-furnished services and items-delivery systems, and apply to administration of new contracts. 
DOE-ID accomplishes its cleanup mission through two primary contractors. The ICP contractor is CWI and the AMWTP contractor is ITG. The DOE-ID/ICP planned work activities for the next 10 years, which support the DOE-NE mission at INL, are structured to meet the milestones specified in the Idaho 1995 Settlement Agreement, Site Treatment Plan, and Federal Facility Agreement and Consent Order. DOE-ID/ICP implements a Life-Cycle Baseline (LCB) planning process designed to describe DOEID/ICP's vision to satisfy its regulatory commitments. The LCB describes the programmatic objectives and the resources to complete the ICP mission. The TYSP is updated as the LCB matures and as the nearterm programmatic objectives are accomplished. The DOE-ID/ICP environmental management funding profile for FY 2013 through FY 2024 is shown in Table C-1.

Table C-1. Department of Energy Idaho Operations Office of Environmental Management profile (Fiscal Year 2013 to Fiscal Year 2024).

\section{Environmental Management Funding (\$M)}

\begin{tabular}{|l|l|l|l|l|l|l|l|l|l|l|l|l|}
\hline Fiscal Year & $\mathbf{2 0 1 3}$ & $\mathbf{2 0 1 4}$ & $\mathbf{2 0 1 5}$ & $\mathbf{2 0 1 6}$ & $\mathbf{2 0 1 7}$ & $\mathbf{2 0 1 8}$ & $\mathbf{2 0 1 9}$ & $\mathbf{2 0 2 0}$ & $\mathbf{2 0 2 1}$ & $\mathbf{2 0 2 2}$ & $\mathbf{2 0 2 3}$ & $\mathbf{2 0 2 4}$ \\
\hline Funding & $\$ 360$ & $\$ 370$ & $\$ 370$ & $\$ 370$ & $\$ 370$ & $\$ 370$ & $\$ 370$ & $\$ 398$ & $\$ 408$ & $\$ 418$ & $\$ 428$ & $\$ 439$ \\
\hline
\end{tabular}

The significant work activities and milestones are summarized below:

- Complete transfer of UNF from wet storage facilities by December 31, 2023. The UNF storage pool at INTEC CPP-666 is the only remaining DOE-managed wet storage facility on the INL Site.

- Complete removal of $65,000 \mathrm{~m}^{3}$ of TRU waste from Idaho to the Waste Isolation Plant (WIPP) no later than December 31, 2018.

- Continue targeted TRU waste exhumation of 2.58 acres in the SDA at RWMC; completion anticipated by FY 2024.

- Complete calcination (steam reforming treatment) of sodium bearing waste by end of Calendar Year 2014.

- Complete closure of the four remaining high-level waste tanks at INTEC.

- Complete Resource Conservation and Recovery Act (RCRA) closure of the INTEC tank farm.

- Install an interim cover on the INTEC tank farm by 2017.

- Continue remediation of contaminated groundwater at TAN.

- Position DOE-ID/ICP for the repackaging and disposition of UNF by 2035.

- Complete design and initiate construction of a calcine treatment facility to support retrieving, treating, packaging, and storing approximately $4,400 \mathrm{~m}^{3}$ of calcine.

- Continue receipt of domestic research reactor (DRR) and foreign research reactor (FRR) fuel and ATR fuel at INTEC.

- Maintain remote-handled TRU waste characterization, treatment, packaging, and shipment in support of the Idaho Settlement Agreement requirements. 
- Maintain safe and compliant storage of UNF at INL and Fort St. Vrain (FSV).

- Renew the NRC license for the Three-Mile Island (TMI) Independent Spent Fuel Storage Installation (ISFSI).

- Continue with decommissioning, deactivation, and demolition of nuclear, radiological, and industrial facilities that no longer have an environmental management mission.

- Maintain and implement Comprehensive Environmental Response, Compensation, and Liability Act (CERCLA) program and associated institutional controls.

A high-level summary schedule forecast (as of February 2013) for completion of this scope of work is shown in Figure C-1. Specific near-term work activities projected in the ICP and AMWTP contracts are summarized in the following sections.

\section{C-1.1.1 Scope and Schedule}

Section C.8 of the ICP contract, as amended by contract modifications, defines the "target" scope of work planned to be completed by September 30, 2015. In addition to the target scope, ICP work is being conducted under Section B.16 (items not included in target cost) of the contract. The projected work scope to be completed by the ICP contractor under the current contract is summarized below.

\section{Spent Nuclear Fuel (PBS ID-0012)}

- Maintain all ICP-assigned UNF, UNF facilities, and UNF records

- Maintain the CPP-666 fuel storage basin and the non-DOE-EM assigned UNF currently stored in the basin

- Complete transport of the two West Valley UNF casks from the railroad siding to CPP-2707, Dry Spent Fuel Cask Storage Pad

- Provide management of the NRC licensed facilities, in accordance with the license basis documents, including commitments made to the NRC for the TMI ISFSI, ISFF at INTEC, and the FSV ISFSI in Colorado

- Support DOE in actions with NRC, such as preparation of technical evidence to support license renewal and an aging management program for the TMI ISFSI, NRC inspections, and resolution to requests for information

- Provide surveillance and monitoring, and implement a comprehensive preventative maintenance program for all INTEC UNF storage facilities through the duration of the contract

- Maintain the capability to receive DRR/FRR Program UNF.

\section{Solid Waste Disposition (PBS ID-0013)}

- Perform all work necessary to place Idaho Settlement Agreement remote- and contact-handled TRU waste into a configuration that meets WIPP waste acceptance criteria and complete final disposition. 


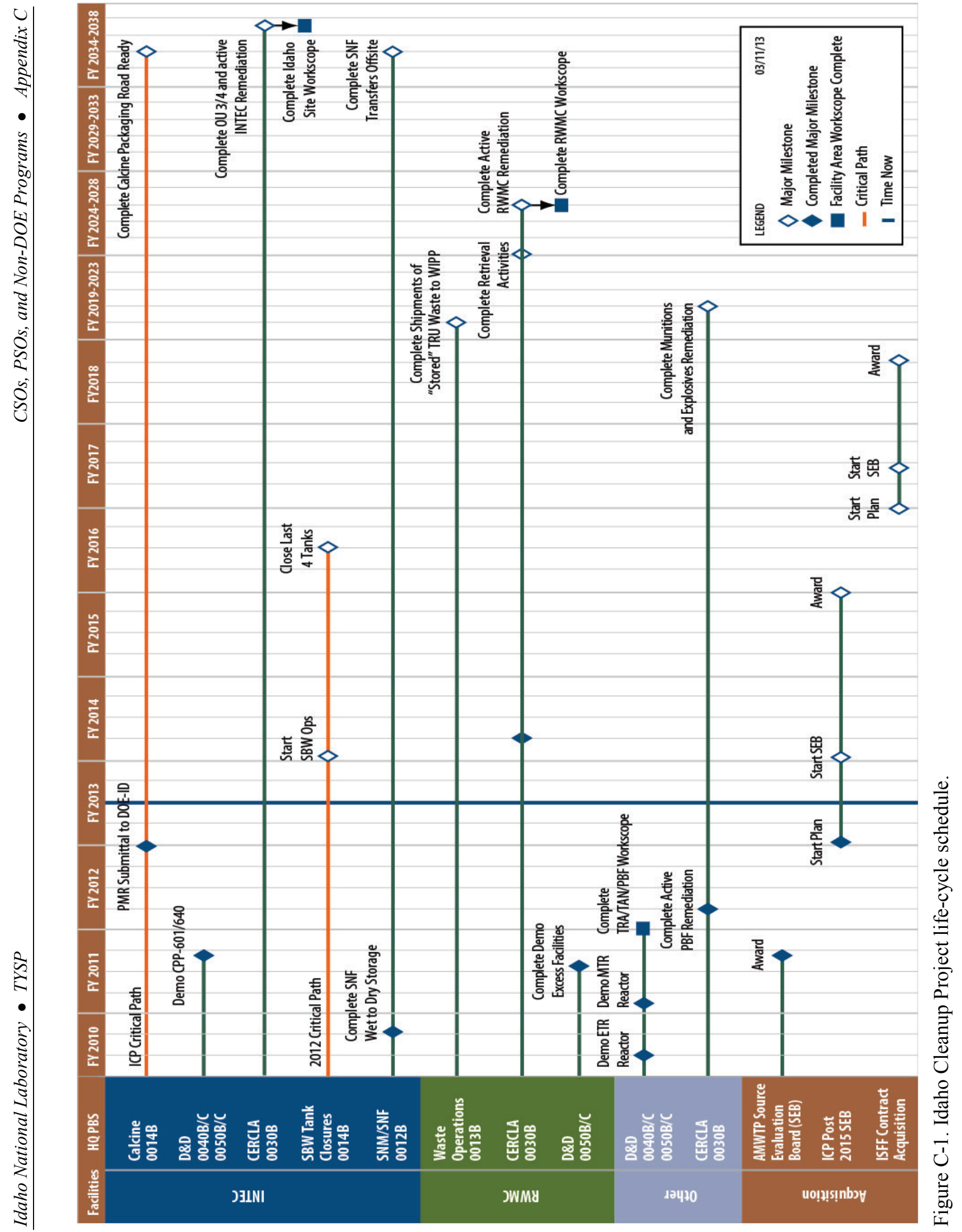




\section{General Waste Management}

- Comply with RCRA post closure requirements for CPP-601/627/640 and the Waste Calcine Facility

- Perform sampling and report results for the drinking water systems at INTEC and RWMC

- Dispose of solid waste generated as a result of cleanup activities

- Prepare and package DOE-EM-owned and generated hazardous waste and ship to an appropriate treatment or disposal facility

- Safely manage and disposition contact-handled and remote-handled LLW waste generated by on-site DOE-EM generators

- Dispose of DOE-EM-owned MLLW that is stored on-site and/or generated by DOE-EM activities at either a commercial or government disposal facility

- Dispose out of the State of Idaho all targeted waste retrieved and packaged from SDA that is assayed as LLW or MLLW.

\section{RWMC Infrastructure}

- Maintain building WMF-658 and physical and utility interfaces with the AMWTP site

- Maintain RCRA permit and Toxic Substances Control Act (TSCA) disposal approval for Accelerated Retrieval Project (ARP) V and treat 6,000 drums of AMWTP waste.

\section{Liquid Waste Disposition (PBS ID-0014) \\ INTEC Programs}

- Provide RCRA closure of the entire INTEC Tank Farm as per the approved RCRA closure plan

- Maintain INTEC facilities and infrastructure systems

- Maintain calcine bin sets and RCRA storage permits.

\section{Integrated Waste Treatment Unit (IWTU) Operations/Sodium Bearing Waste (SBW) Disposition}

- Finish the necessary plant testing and achieve "cease use" milestone for SBW

- Remove and treat residual liquids (i.e., heel, rinse, and newly generated liquid waste) and support the transition of the IWTU facility to a safe and secure configuration after SBW treatment is complete, and perform final turnover to the Calcine Disposition Project.

\section{Non-Target (B.16) Scope}

- Transfer Navy fuel stored at INTEC to dry storage at NRF. 


\section{Soil and Groundwater Remediation (PBS ID-0030)}

- Maintain compliance with the CERCLA signed Records of Decision for Waste Area Groups (WAGs), as listed in the ICP contract Statement of Work

- Complete exhumation of targeted waste of 0.51 acres of the 2.58 acres that remain at SDA

- Dispose of contact-handled TRU waste generated by packaging and delivering waste to the AMWTP contractor

- Maintain existing ARP structures

- Perform groundwater monitoring and operation and maintenance (O\&M) of the monitoring wells

- Maintain the functions of the existing vacuum vapor extraction system to remove organic contaminants from the vadose zone

- Plan, conduct, and document groundwater, perched water, vapor gas, and soil moisture monitoring for WAGs 1, 2, 3, 4, 7, and 10 and the Idaho CERCLA Disposal Facility (ICDF) in accordance with approved WAG specific monitoring plans

- Maintain the current CERCLA well monitoring network

- Maintain CERCLA institutional controls and O\&M for WAGs 1, 2, 3, 4, 5, 6, 7, 9, and 10 and ICDF in accordance with the INEEL Site-wide Institutional Controls and Plan (DOE-ID 2004).

\section{C-1.1.2 Staffing}

ICP staffing will be aligned with project work scope, as necessary, throughout the course of the contract. Figure C-2 shows currently projected ICP staffing through the year 2015.

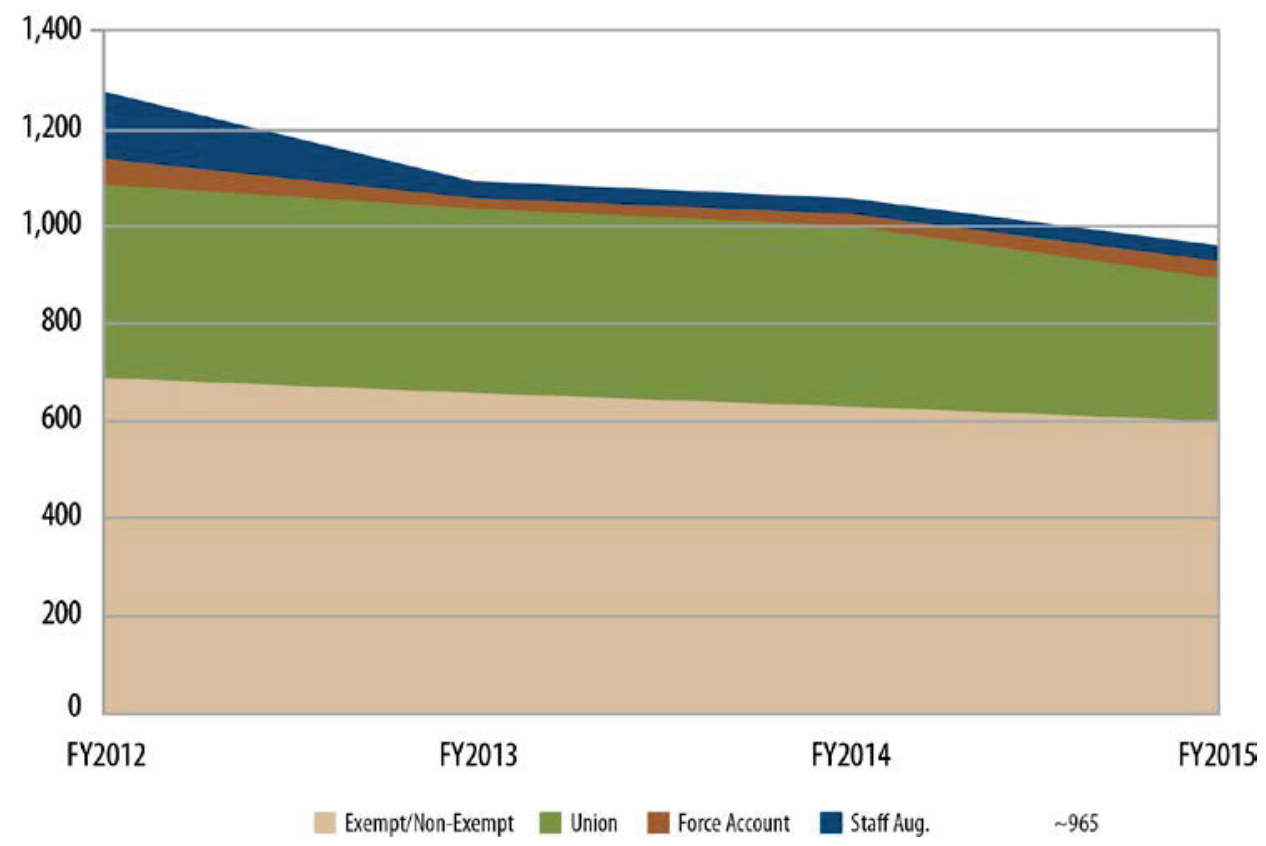

Figure C-2. Projected Idaho Cleanup Project staffing for full-time equivalents averaged over the fiscal year. 


\section{C-1.1.3 Facilities and Infrastructure Overview}

A breakdown of building ownership showing DOE-EM-owned buildings assigned to ICP versus DOE-NE-owned buildings is available in the FIMS database. As of March 2013, the FIMS database showed 123 DOE-EM-owned buildings and trailers at INL assigned to ICP, with a total area of $1,279,717 \mathrm{ft}^{2}$. DOE-EM owned facilities that are candidates for transfer to support DOE-NE's multiprogram mission needs are discussed in Section 2.4.4.

Table C-2 provides a description of the buildings assigned to ICP and their overall operating status, size, age, usage, and hazard description.

The current conditions of existing DOE-EM buildings assigned to ICP are illustrated in Figure C-3.

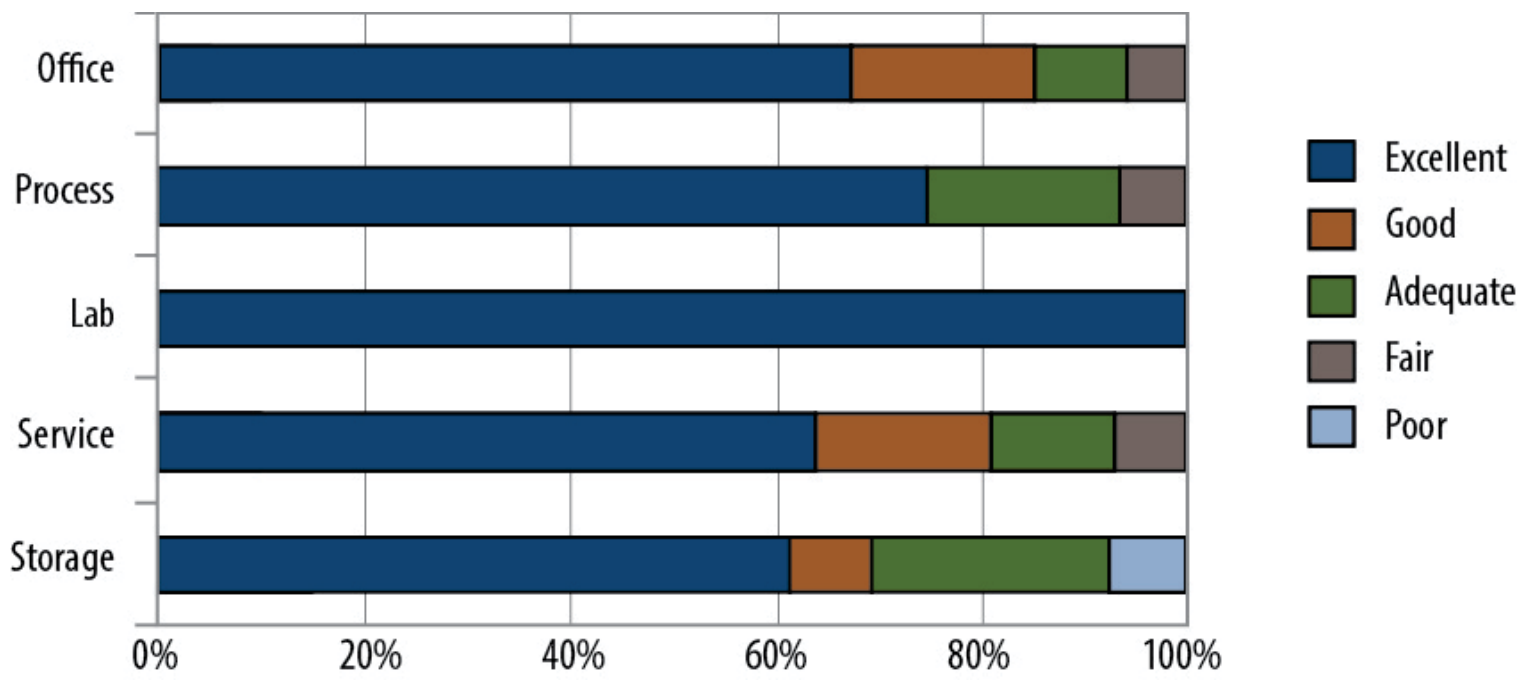

Figure C-3. Fiscal Year 2012 Facility Information Management System Conditions of Department of Energy Office of Environmental Management buildings assigned to the Idaho Cleanup Project.

\section{C-1.1.3.1 Maintenance}

ICP will continue to maintain mission essential facilities/utility systems in accordance with DOE Order 430.1B, Chg. 2. Facilities/utility systems that no longer have a defined mission, and are considered candidates for decommissioning, will continue to undergo surveillance and maintenance adjustment according to DOE Guide 430.1-2, Implementation Guide for Surveillance and Maintenance during Facility Transition and Disposition.

A graded approach is implemented for surveillance and maintenance by ICP. The graded approach being used is commensurate with the facility/utility system's condition, mission need, and schedule for demolition.

Maintenance, whether preventive, predictive, or corrective, is performed at a level to sustain property in a condition suitable for the property to be used for its designated purpose.

Surveillance is the scheduled periodic inspection of facilities, utility systems, equipment, or structures to demonstrate compliance, identify problems requiring corrective action, and determine the facility's present environmental, radiological, and physical condition. Facility/utility systems will be considered for recommendation of recapitalization based on facility/utility system conditions established by scheduled surveillance/inspections and the estimated remaining duration of the facility/utility system's mission. 


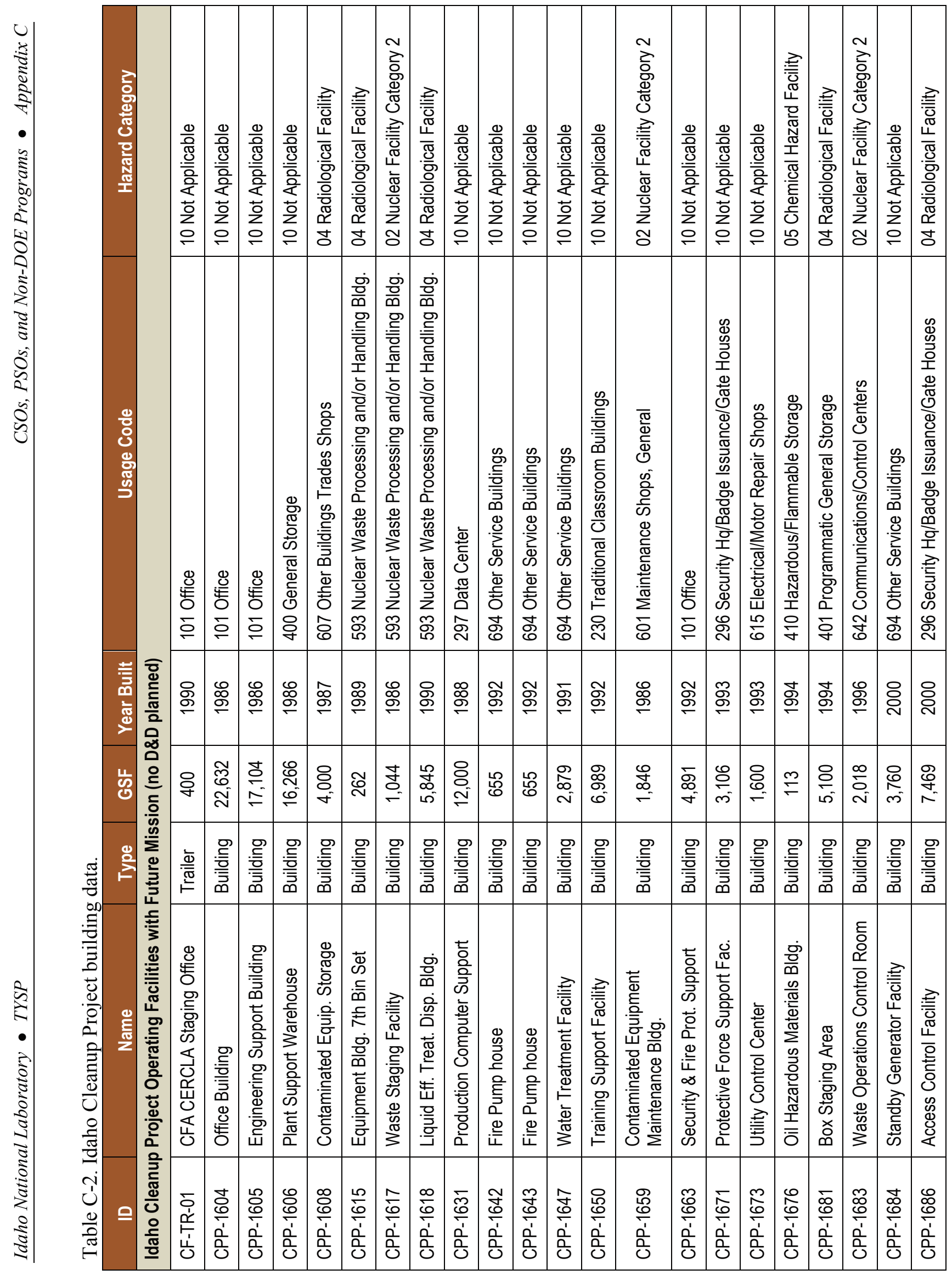




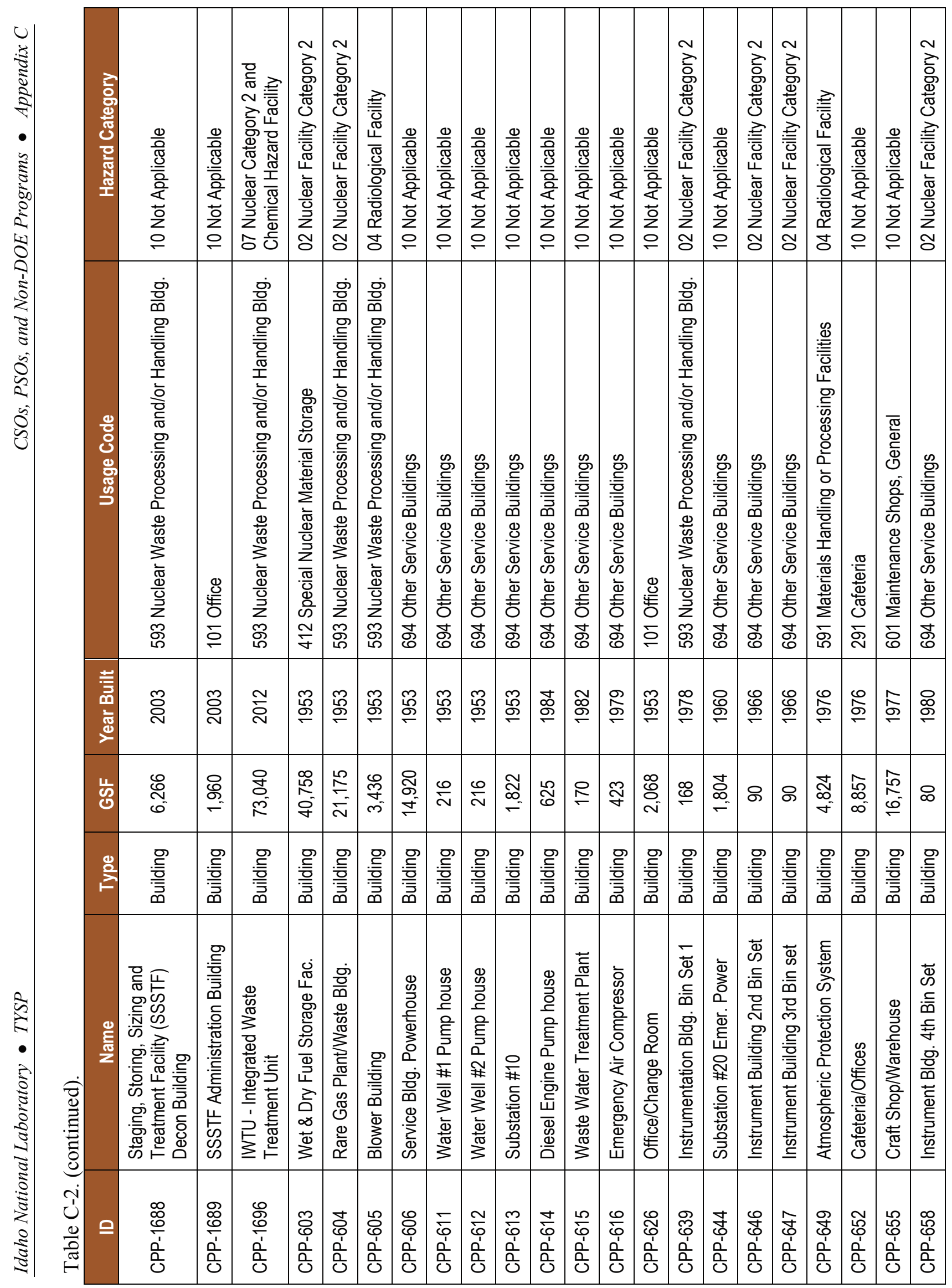




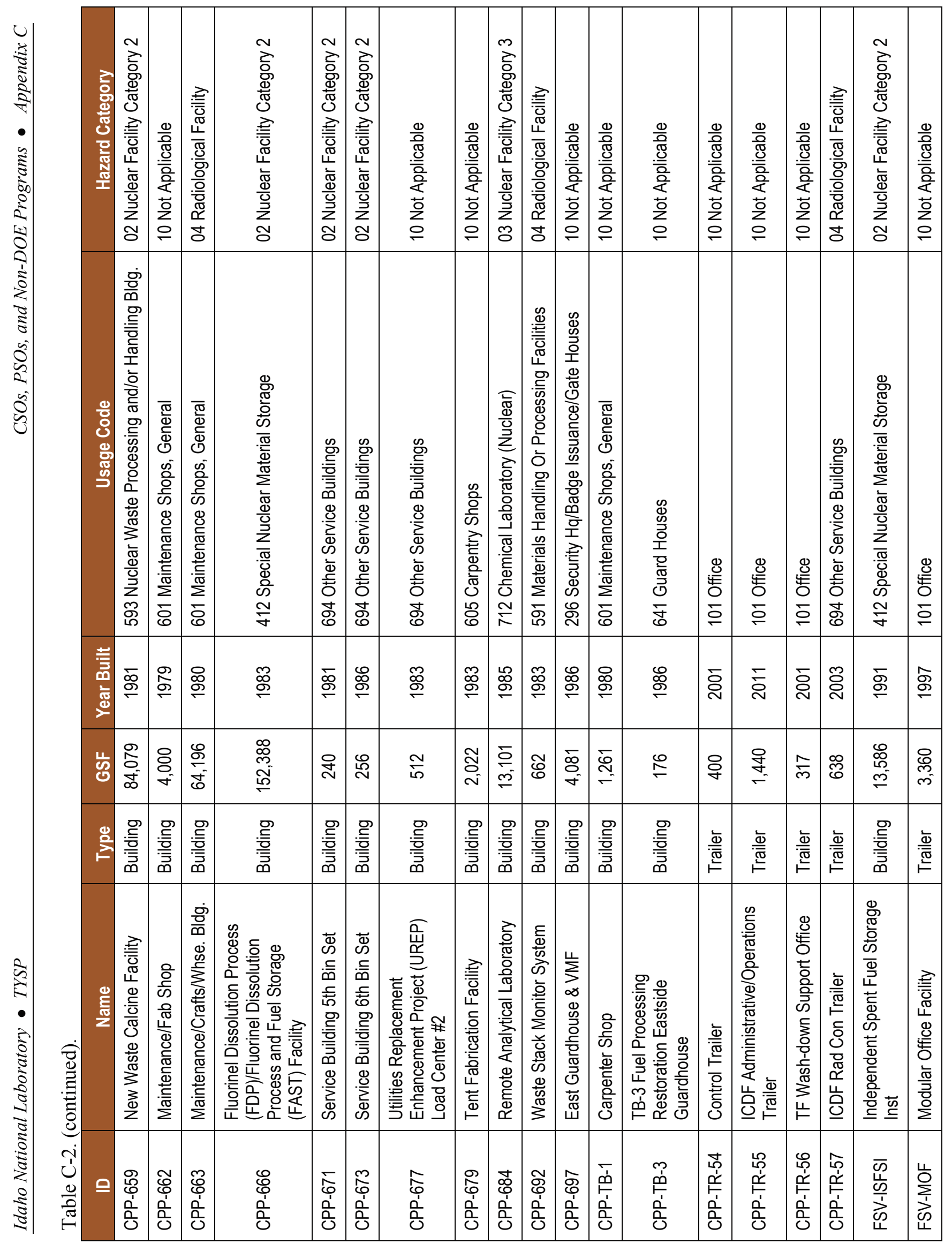




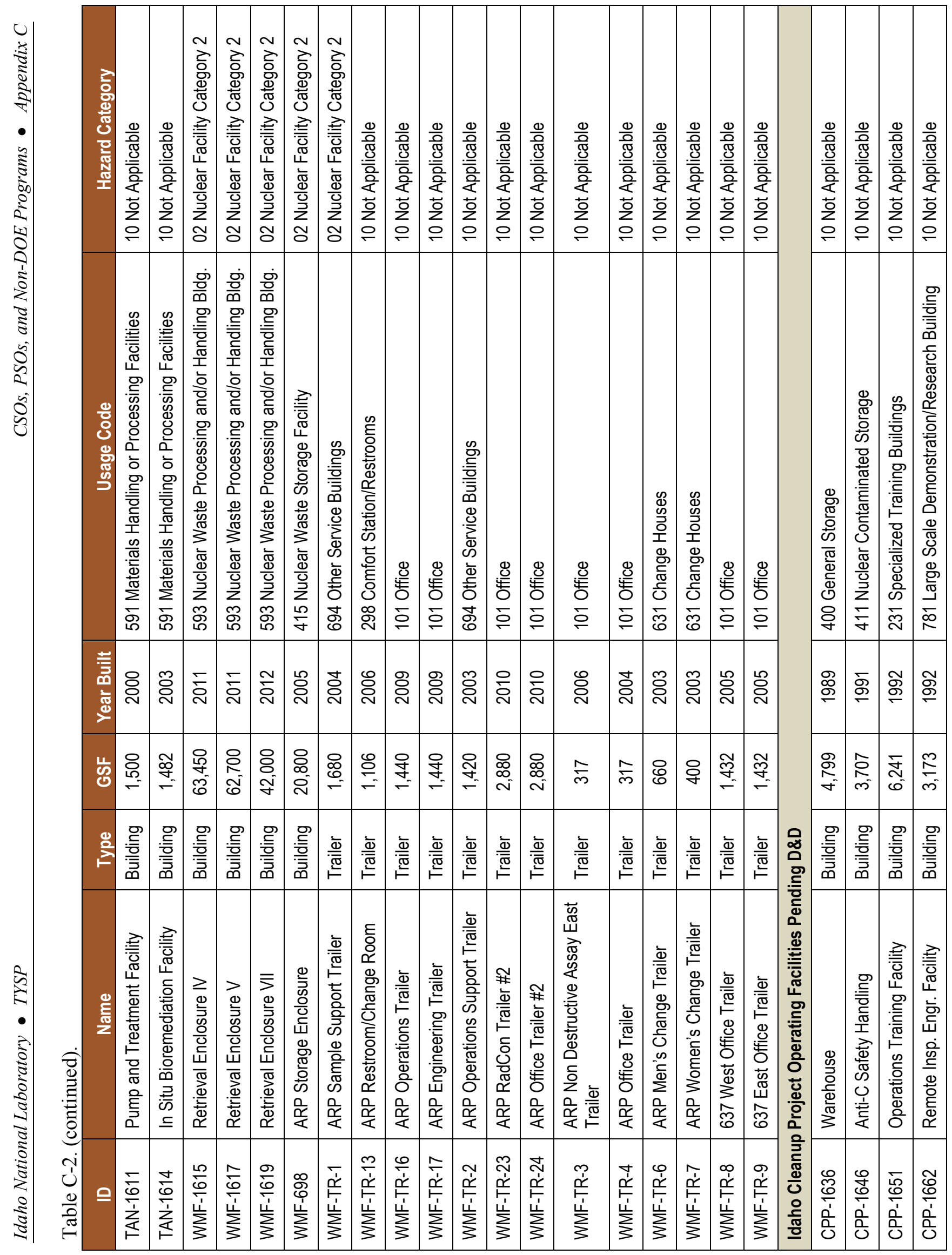




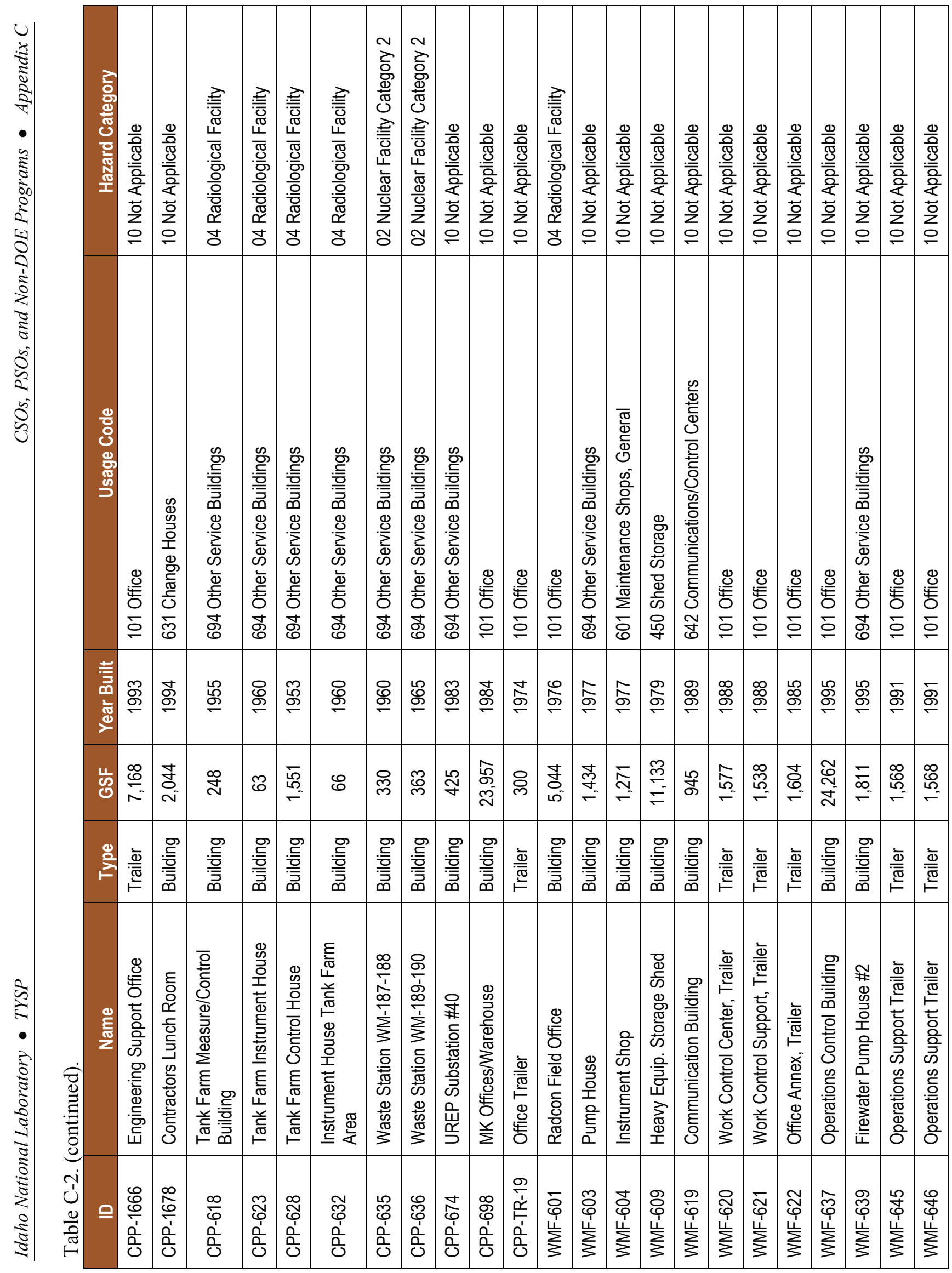




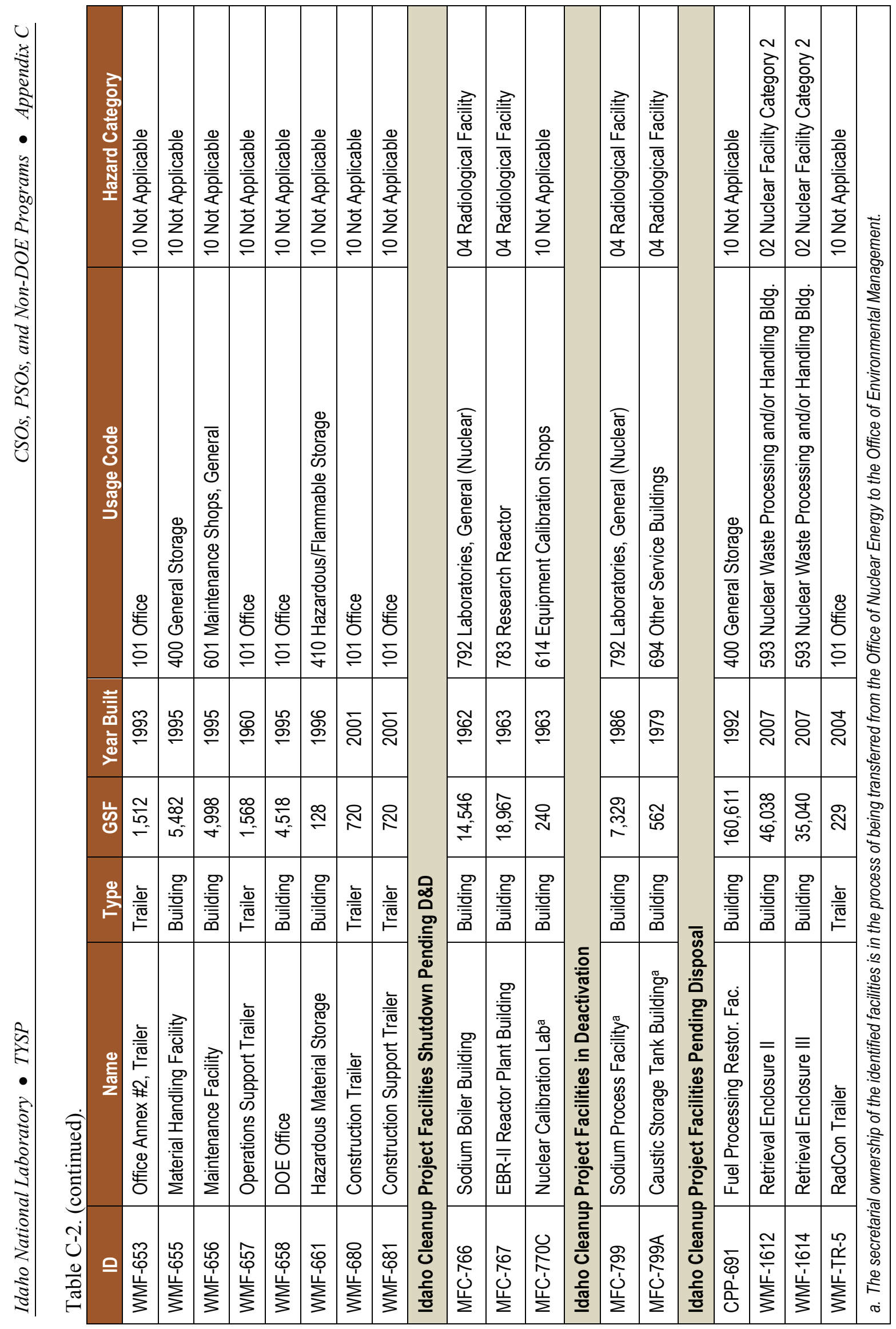


Table C-3 is a list of the proposed ICP recapitalization projects for facilities, structures, systems, and equipment. Recapitalization recommendations will be described in the CAIS database section for the identified facility/utility system. Surveillance will be performed in a manner that ensures protection of the worker, the public, and the environment.

Facility management, with assistance from designated experts in each discipline, will identify facilityspecific surveillance and maintenance activities. The source of any such surveillance requirements and the end points at which the surveillance and maintenance activities can be stopped for facilities and structures slated for D\&D also will be identified.

Any reduction in surveillance and maintenance will be justified and documented in accordance with company procedures.

ICP also is responsible for over 115 small support structures (e.g., septic tanks, fuel storage tanks, and concrete pads). These structures are identified in the FIMS database as OSFs and are not specifically addressed in this discussion. They include facilities such as CPP-749 (underground storage vaults for Peach Bottom fuel), CPP-1774 (TMI 2 dry storage modules), and CPP-2707 (dry UNF cask storage pad).

\section{C-1.1.3.2 Utilities}

Utilities and operations DOE-EM funds directly support site area missions. Utilities services and funding outside the site areas are maintained and operated by the Lead PSO (DOE-NE).

The ICP cleanup mission covers four areas - INTEC, RWMC, TAN, and MFC. The RWMC utility systems are structurally sound and are expected to sustain operations until mission completion without major upgrades. The utility systems will be maintained as described in Section C-1.1.3.1.

The INTEC electrical distribution system received a major upgrade (completed in FY 2003) using lineitem construction project funding. The underground water systems are old (i.e., over 40 years of service) and may require upgrades. Utility systems that are considered part of the Vital Safety Systems will be maintained as priorities, and the remaining utilities will have maintenance conducted and recapitalization projects as described in Section C.1.1.3.1. Utility maintenance and upgrades undergo continual evaluation to ensure successful completion of the ICP mission. Utility deficiencies are evaluated in conjunction with facility mission needs, sustainability objectives, D\&D plans, and potential transfer to DOE-NE.

The TAN and MFC utilities are maintained through DOE-NE funding.

Utility systems will be considered for recommendation of recapitalization based on utility conditions established by scheduled surveillance/inspections and the estimated remaining duration of the utility mission. Recapitalization recommendations will be described in the CAIS database section for the identified utility system. 


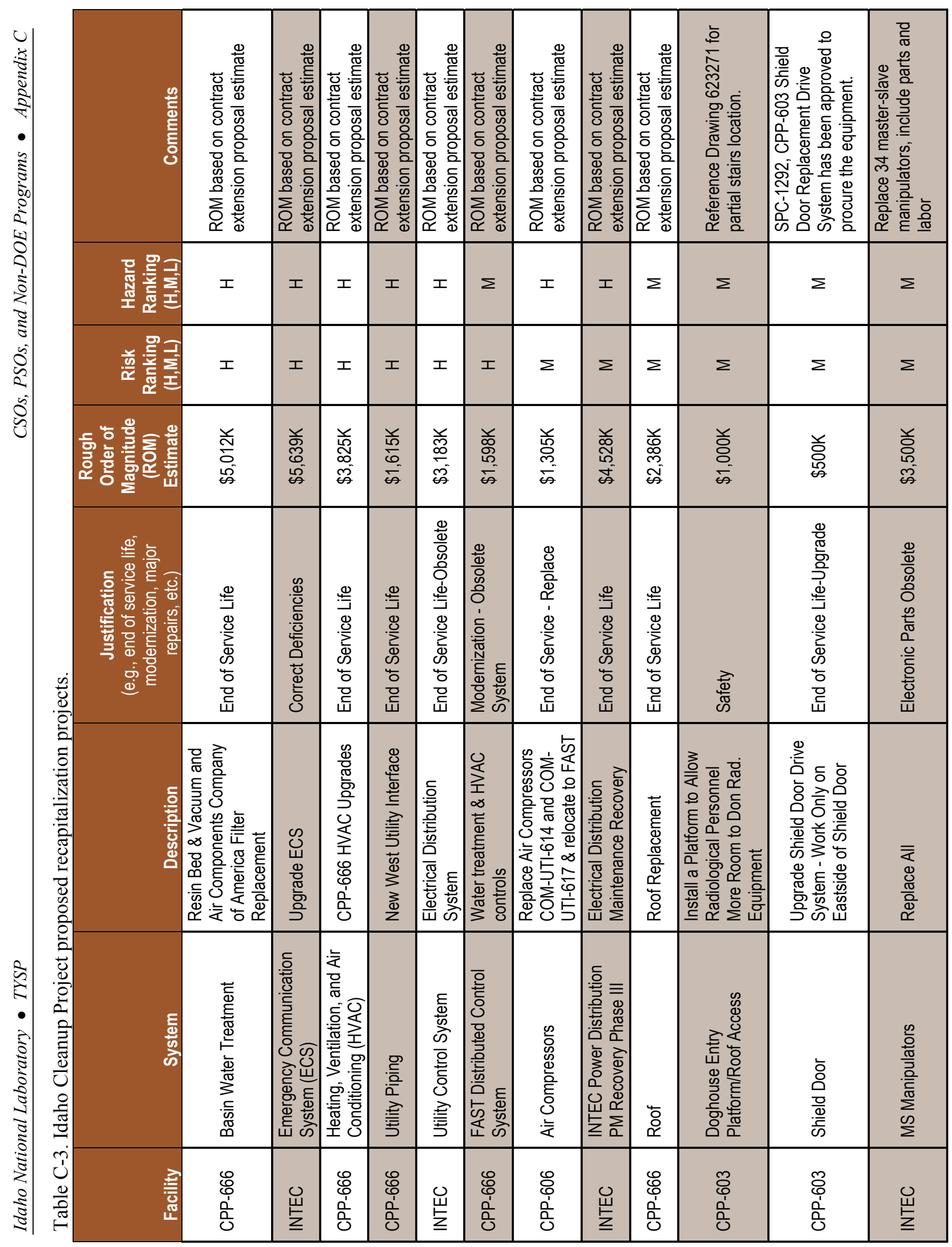




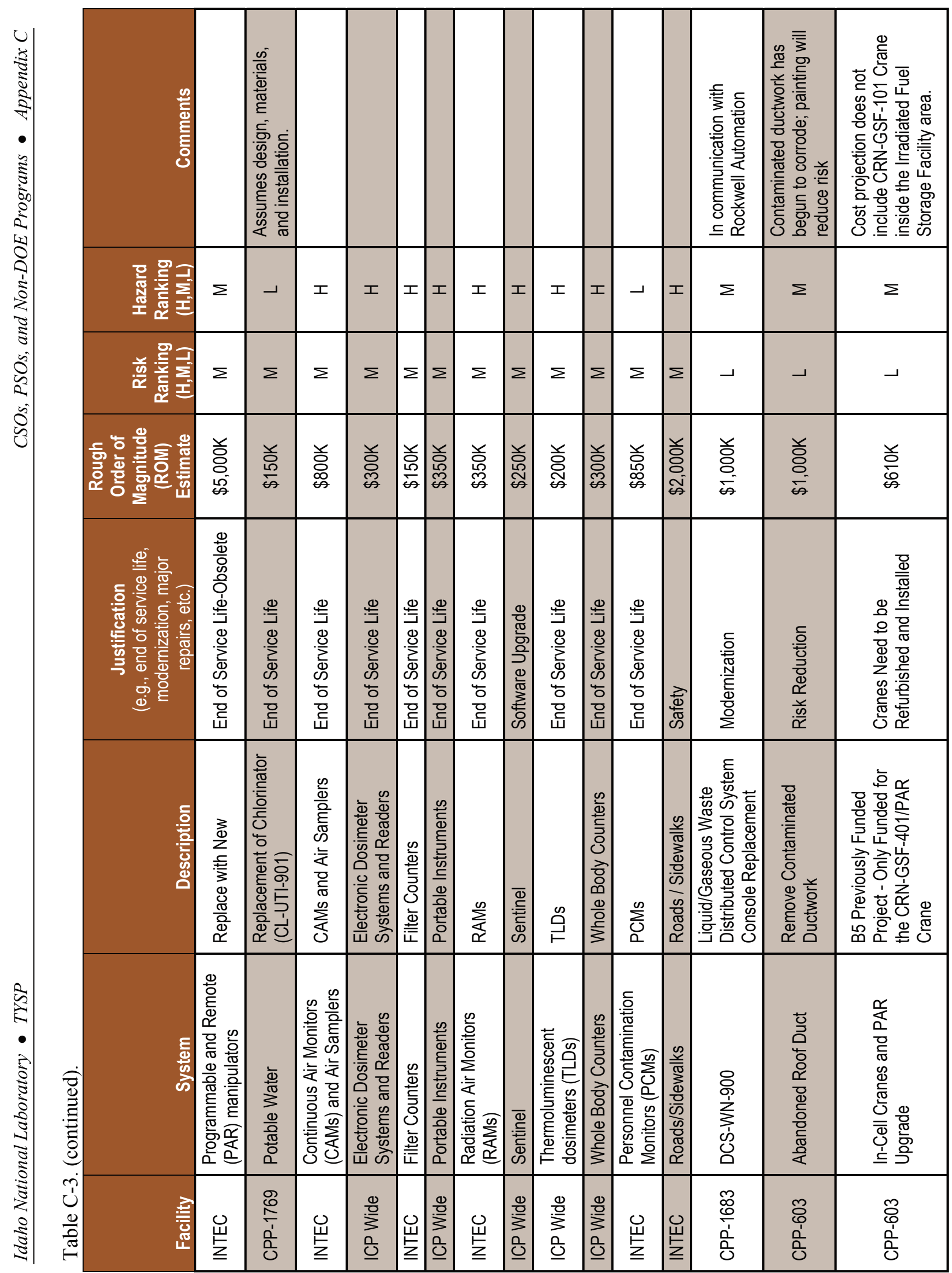




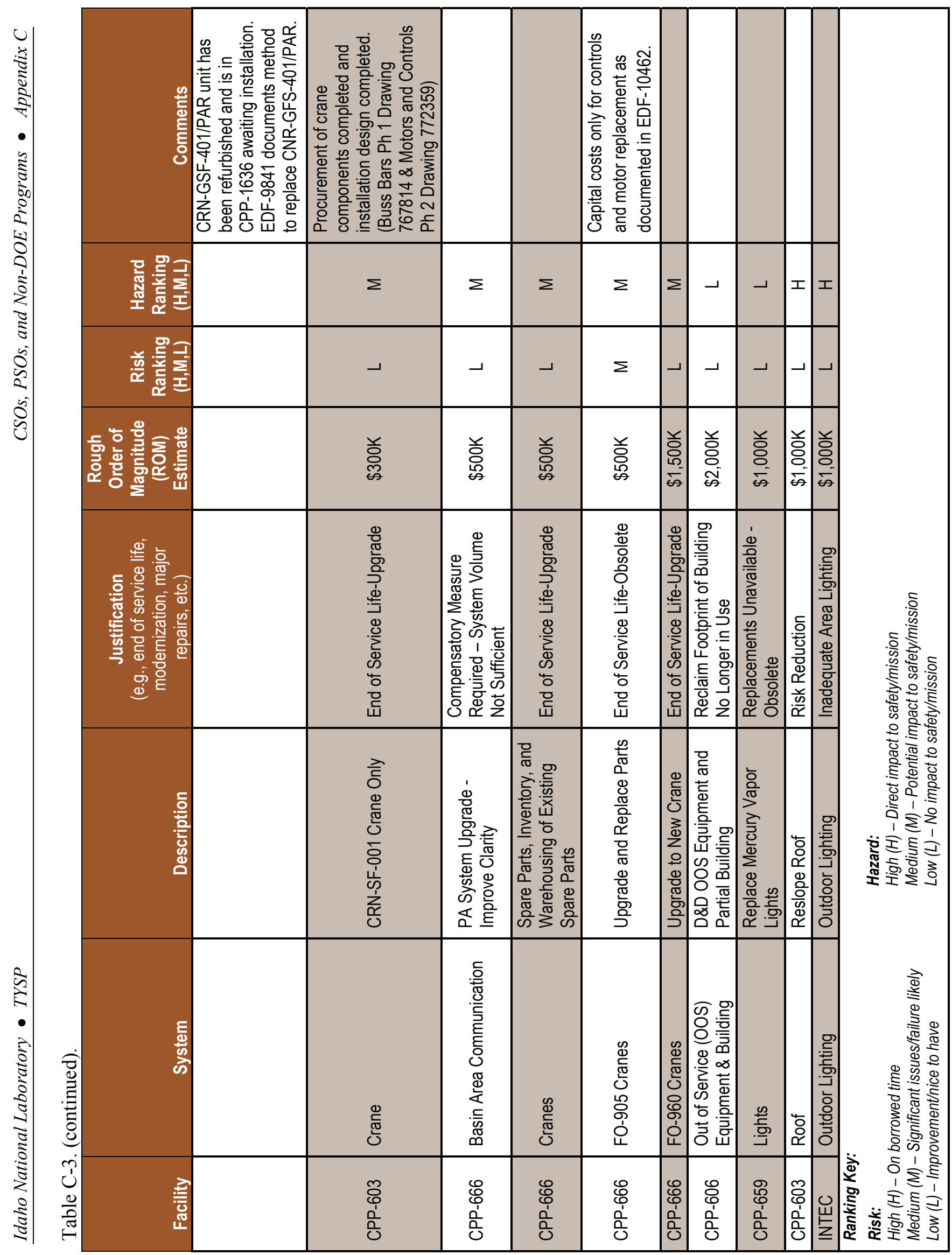




\section{C-1.1.3.3 Sustainability Management}

With regard to sustainability management, ICP is focusing its efforts on strategies and activities that will lead to continual greenhouse gas, energy, water, and transportation fuels efficiency to aid the INL Site toward meeting the goals and requirements of the DOE Strategic Sustainability Performance Plan (SSPP; DOE 2012), Executive Order (EO) 13514, "Federal Leadership in Environmental, Energy, and Economic Performance," and DOE Order 436.1, Departmental Sustainability before the end of FY 2020. For ICP, the INL SSP (DOE-ID 2012) identifies the company environmental management system (EMS) as the process to identify and review associated company level sustainability goals, objectives, and actions to aid DOE in meeting these goals. The plans' identified ICP EMS activities to support the INL Site in achieving these currently funded goals are:

- Continuation of pre-existing work scope sustainability tracking/reporting activities

- Establishment of new annual energy and water conservation objectives and targets at INTEC

- Continuation of ICP existing practices to optimize the use of alternative fuel vehicles and hybrids using General Services Administration (GSA) vehicle sources

- Continuation of ICP existing practices for electronic stewardship, chemical substitution, and sustainable material acquisition

- Continuation of waste diversion practices to reduce nonhazardous/nonradioactive solid waste (excluding construction and demolition debris) and construction and demolition debris from disposal in landfills.

Additional identified potential ICP EMS sustainability activities that remain subject to equitable adjustment approvals and availability of priority funding are based upon recently added DOE Order 436.1, five federal and DOE acquisition clauses, related specific sustainability contract directions provided in the ICP contract extension, and related DOE-ID proposed sustainability directions currently under contract discussion. These sustainability activities include:

- Implementation of additional sustainability-related acquisition tracking/reporting actions.

- Implementation of additional electronic equipment power reduction actions (e.g., default duplex copy/printing, workstation power down mode, etc.).

- Implementation of additional GSA-directed practices for disposition of excess/surplus electronic equipment.

- Facility support for DOE-ID direct subcontract activities for advanced energy/water/steam meter installation at up to 12 INTEC buildings.

- Evaluation of potential cool roof installation at CPP-666.

- $\quad$ Energy management training for ICP facility managers by September 2013.

- Performance of building energy surveys of ICP managed enduring (active, post 2020) buildings.

- For waste diversion, tracking/reporting of waste quantity diversion rates for nonhazardous/ nonradioactive solid waste. This includes identifying and implementing actions to support increased diversion rates toward the goal of 50\% diversion or providing DOE-ID analysis to demonstrate unsatisfactory cost-benefit impact on accomplishing scope or non-availability of diversion availability. 


\section{C-1.1.3.4 Operating Facilities with Ongoing Missions (no D\&D planned under ICP contract)}

The ICP is responsible for 117 facilities ( 87 buildings and 30 trailers) with ongoing missions (i.e., facilities needed to complete the cleanup mission that are currently operating and not scheduled for D\&D under the ICP contract). These include facilities for UNF storage, waste storage and processing, and for fire protection and security installations.

\section{C-1.1.3.5 Facilities Scheduled for D\&D}

The portion of the ICP extension contract work scope involving D\&D of excess facilities has been reserved as additional work scope to be added pending availability of funding. Completion of RCRA closure and deactivation of MFC-799, and deactivation and demolition of MFC-799A, are planned by September 30, 2015. Longer term D\&D planning of ICP facilities beyond 2015 takes into consideration mission completion at Site areas (e.g., RWMC), future use of significant infrastructure assets (e.g., INTEC boilers), potential transfer to DOE-NE, and deliberate planning to avoid a large number of facilities undergoing D\&D in a short period of time.

\section{C-1.1.3.6 Deactivated Facilities}

As noted above, two facilities (MFC-799 and -799A) are in the deactivation stage (Table C-4). Following operational shutdown and transition, the first disposition activity for these facilities is usually to deactivate the facility. The purpose of deactivation is to place a facility in a safe shutdown condition that is cost effective to monitor and maintain for an extended period until the eventual decommissioning of the facility. Deactivation places the facility in a low-risk state with minimum surveillance and maintenance requirements.

Table C-4. Idaho Cleanup Project building deactivation.

\begin{tabular}{|c|l|l|r|r|l|l|l|}
\hline \multicolumn{1}{|c|}{ ID } & \multicolumn{1}{|c|}{ Name } & \multicolumn{1}{c|}{ Type } & GSF & $\begin{array}{r}\text { Year } \\
\text { Built }\end{array}$ & \multicolumn{1}{c|}{ Usage Code } & Hazard Category \\
\hline \multicolumn{2}{|c|}{ Idaho Cleanup Project Facilities in Deactivation } \\
\hline MFC-799 & Sodium Process Facility & Building & 7,329 & 1986 & $\begin{array}{l}792 \text { Laboratories, } \\
\text { General (Nuclear) }\end{array}$ & 04 Radiological Facility \\
\hline MFC-799A & $\begin{array}{l}\text { Caustic Storage Tank } \\
\text { Building }\end{array}$ & Building & 562 & 1979 & $\begin{array}{l}\text { 694 Other Service } \\
\text { Buildings }\end{array}$ & 04 Radiological Facility \\
\hline
\end{tabular}

\section{C-1.1.3.7 Deferred Maintenance}

DM will be reported in FIMS for those DOE-EM buildings with a designation of "Operating" (i.e., no D\&D under the ICP contract). Reported DM will be based on existing values for DM and information resulting from scheduled facility-condition-assessment survey inspections. Should facility inspections or surveillance activities identify the need to perform maintenance that has been deferred, ICP engineering and cost estimating will help establish that cost, and it will be reported accordingly. However, because the ICP life-cycle baseline does not include any specific capital projects for the reduction of DM, baseline changes will be pursued as necessary to address the issue.

\section{C-1.1.4 Conclusions}

By the completion of the ICP extension contract, the following ICP achievements will have resulted in significant risk reduction at INL: 
- Shipping a large quantity of the stored TRU waste to WIPP for final disposition

- Treatment of the liquid SBW

- Exhumation of a large majority of the targeted waste at SDA.

While the ICP contract ends in the year 2015, there will be substantial DOE-EM scope to complete beyond that date. That scope includes:

- Shipping the remaining TRU waste to WIPP

- Completing RCRA Closure of INTEC Tank Farm (empty and grout the last four tanks)

- Completing the Calcine Disposition Project

- Continuing to operate the vapor vacuum extraction units at RWMC

- Cleaning up soils under INTEC buildings

- Finishing capping the INTEC Tank Farm area

- Continuing the packaging and final disposition of UNF

- Capping the SDA at RWMC.

By the year 2035, the DOE-EM cleanup mission at INL will be complete.

\section{C-1.2 Advanced Mixed Waste Treatment Project Mission}

The AMWTP mission is to retrieve, characterize, treat, certify, and ship from Idaho legacy TRU and MLLW stored at the RWMC TSA. AMWTP is a DOE-EM-funded project managed and operated by ITG.

Beginning in 1970, approximately $65,000 \mathrm{~m}^{3}$ of legacy waste in 55-gallon drums, boxes, and bins were placed on asphalt pads for interim storage at TSA. Waste consists of solid debris, paper, cloth, plastic, rubber, glass, graphite, bricks, concrete, metals, nitrate salts, process sludges, miscellaneous equipment, and residual liquids. Approximately $91 \%$ of the stored waste came from the Rocky Flats Plant, 5\% from the Mound site, and 3\% from Argonne National Laboratories. Nearly all of the stored waste is contacthandled. Waste containers on the pads eventually were covered with tarps and an earthen berm.

Under the Idaho Settlement Agreement (State of Idaho 1995), DOE is required to ship TSA stored waste out of the State of Idaho by a target date of December 31, 2015, but no later than December 31, 2018. DOE and ITG are currently on schedule to meet the agreement.

In the mid-1990s, WMF-636, a 315,000- $\mathrm{ft}^{2}$ enclosure with a ventilation system, was constructed over TSA. Seven storage facilities of $29,000 \mathrm{ft}^{2}$ each were also constructed to stage and characterize waste retrieved from WMF-636. WMF-676, a remotely-operated waste treatment and super-compaction facility was completed in December, 2002.

Approximately $90 \%$ of the waste has been retrieved from WMF-636, and 60\% has been shipped from Idaho. Waste containers remaining to be retrieved include fiberglass reinforced plywood boxes, deteriorated plywood boxes, and 55-gallon drums that were among the first containers placed at TSA. 
Retrieved wastes are undergoing characterization, treatment, certification, and payload assembly for shipping. Characterization activities include an acceptable knowledge evaluation; an investigation of waste container contents using available documentation; various sampling activities; Real Time Radiography, which produces a two-dimensional image of a container's contents; and Non-Destructive Assay, which determines waste's isotopic content. Waste includes both radioactive and RCRA hazardous constituents such as lead and mercury. Some waste also contains TSCA-regulated constituents such as polychlorinated biphenyls and asbestos.

Several waste treatment processes are conducted at AMTWP. They include drum liquids draining and over-packing and manual sludge solidification and repackaging. In the WMF-676 treatment facility, boxed waste is remotely segregated, size-reduced, and super-compacted. Qualifying drums are directly fed into the super-compactor for size-reduction. Compacted drums are loaded into 100-gallon drums for certification, payload assembly, and shipping.

\section{C-1.2.1 Advanced Mixed Waste Treatment Project Facility Status}

WMF-676 was constructed by British Nuclear Fuels, PLC. In April, 2005, all AMWTP facilities and equipment, which were owned by British Nuclear Fuels, PLC, were purchased by DOE. DOE contracted with Bechtel BWXT Idaho, LLC to process and ship waste, and maintain the facilities from 2005 through September 2011. In October 2011, ITG assumed the same responsibilities.

DOE required the WMF-676 design to allow treating INL and/or DOE waste streams from other sites. AMWTP features an advanced, remotely-operated waste sorting, size-reduction and super-compaction facility that could be used to safely process new waste streams from other DOE sites. DOE currently is evaluating options for future AMWTP missions with new waste streams as ITG and DOE-ID continue shipping waste toward meeting the Idaho Settlement Agreement ahead of the December, 2018 commitment.

AMWTP facilities are currently operational and require normal maintenance and repairs. Some facility upgrades may be required through FY 2015 to accommodate the more difficult waste streams. Routine upgrades and facility modifications are expected to continue. Proposed AMWTP recapitalization projects are delineated in Table C-5.

\section{C-2. OFFICE OF NAVAL REACTORS}

Established in 1950 to support development of naval nuclear propulsion, NRF continues to provide support to the U.S. Navy's nuclear powered fleet.

NRF is one of the INL Site's primary facility areas that will continue to fulfill its currently assigned missions for the foreseeable future. NRF is operated by Bechtel Marine Propulsion Corporation, under contract with and direct supervision of the Naval Nuclear Propulsion Program. NRF is not under the purview of DOE-ID; therefore, NRF real property assets information is not available in this plan.

INL provides support services to NRF, including, but not limited to, bus transportation, motor vehicle and equipment use, electrical power, electrical distribution system management, fire department services and firefighter training, telephone and other communications services, roads and grounds maintenance (outside NRF boundaries), medical support services, railroad operations, and specialized machine shop services.

Additionally, ICP routinely dispositions MLLW generated at NRF and has contract instruments in place to treat remote-handled TRU waste and disposition hazardous waste. Remote-handled LLW (via 55-ton scrap casks) is dispositioned at RWMC for NRF. The NRF disposes some of its CERCLA waste at ICDF. 


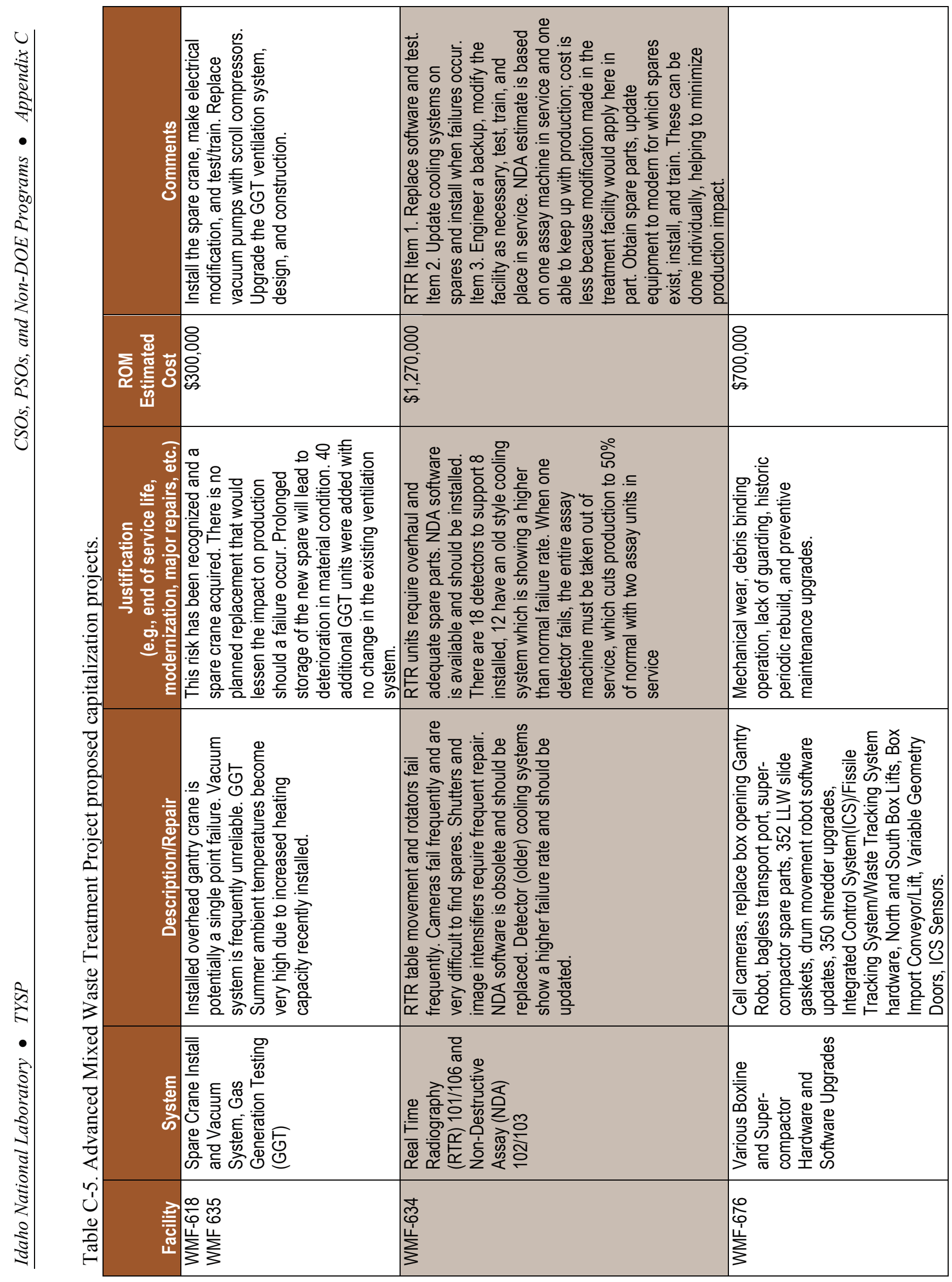




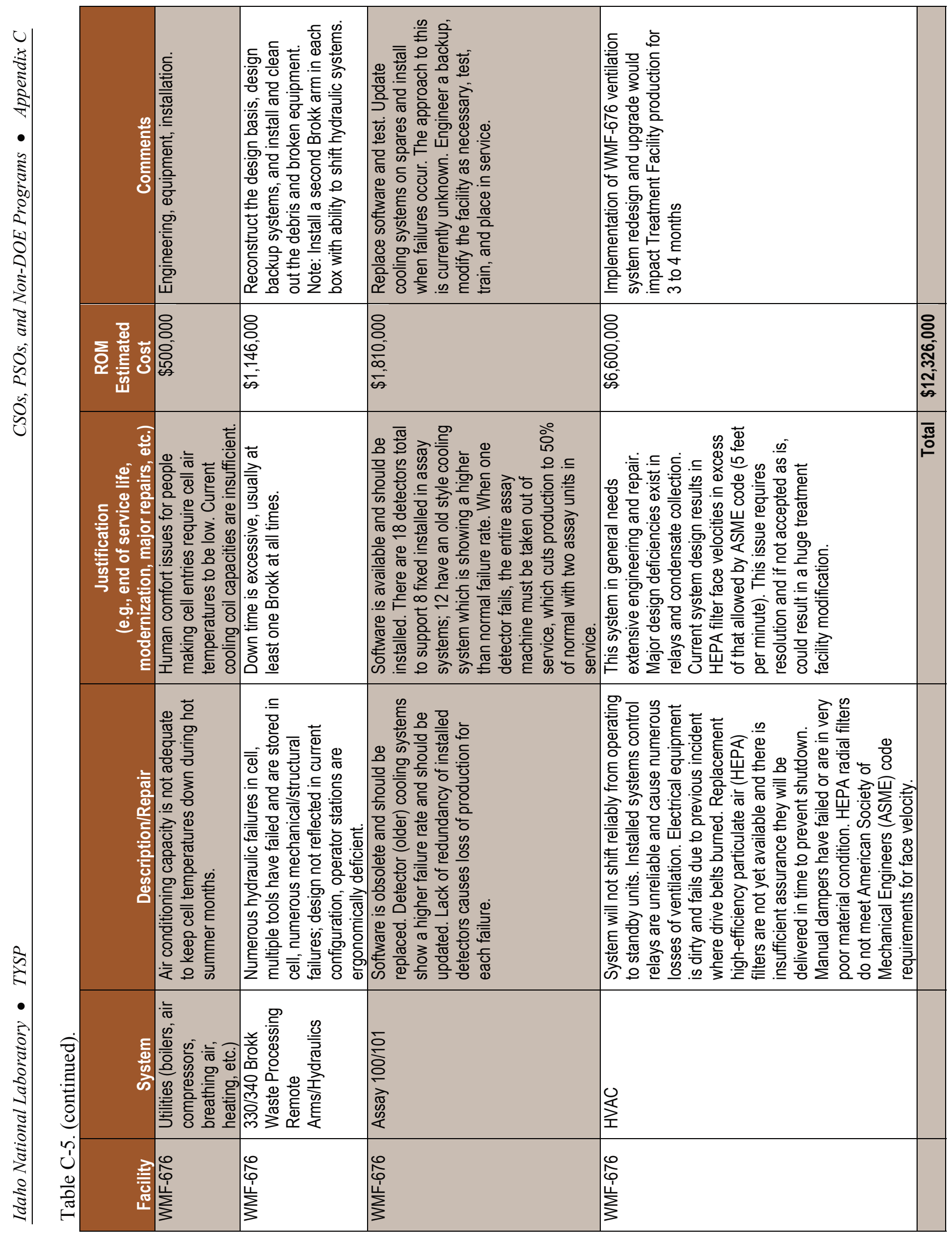




\section{C-3. REFERENCES}

DOE, 2012, DOE Strategic Sustainability Performance Plan, Report to The White House Council on Environmental Quality, Department of Energy, June 2012.

DOE Guide 430.1-2, Implementation Guide for Surveillance and Maintenance during Facility Transition and Disposition, U.S. Department of Energy, September 29, 1999.

DOE Order 430.1B, Real Property Asset Management, Chg. 2, U.S. Department of Energy, September 2003.

DOE Order 436.1, Departmental Sustainability, U.S. Department of Energy, May 2011.

DOE-ID, 2004, INEEL Sitewide Institutional Controls Plan, DOE/ID-11042, Rev. 1, U.S. Department of Energy Idaho Operations Office, June 2004.

DOE-ID, 2012, FY 2013 INL Site Sustainability Plan with the FY 2011 Annual Report, DOE/ID-11383, Rev. 4, Department of Energy Idaho Operations Office, December 2012.

EO 13514, "Federal Leadership in Environmental, Energy, and Economic Performance," Executive Order, October 5, 2009.

State of Idaho, 1995, "Settlement Agreement and Consent Order to fully resolve all issues in the actions Public Service Co. of Colorado v. Batt, No. CV 91-0035-S-EJL (D. Id.) and United States v. Batt, No. CV-91-0065-S-EJL (D. Id.)," Executed October 16, 1995. 


\section{APPENDIX D}
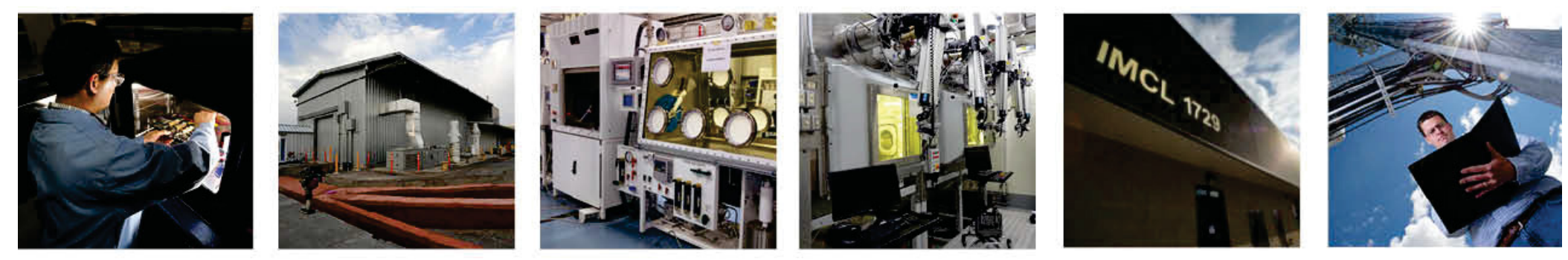

Strategic Sustainability Program 



\section{CONTENTS}

\section{D-1. IDAHO NATIONAL LABORATORY STRATEGY FOR GLOBAL SUSTAINABILITY} LEADERSHIP

D-1.1 Idaho National Laboratory Site Sustainability Plan D-3

D-1.2 Funding D-3

D-1.3 Sustainability Goals D-6

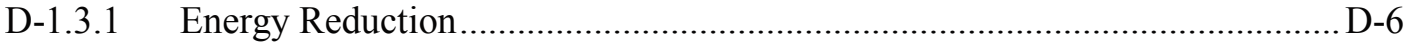

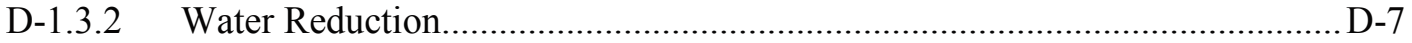

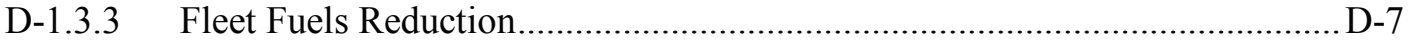

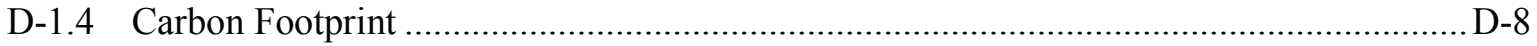

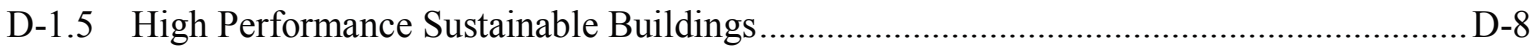

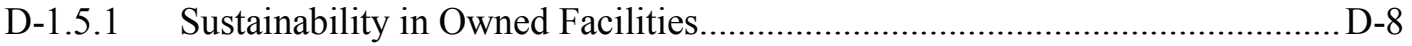

D-1.5.2 Sustainability in Leasing ...................................................................... D-10

D-1.6 Regional and Local Integrated Planning ................................................................. D-10

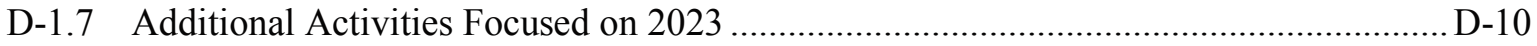

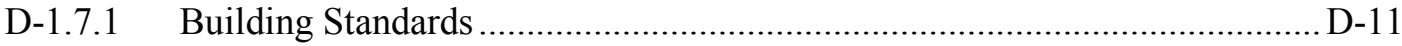

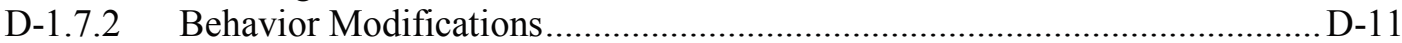

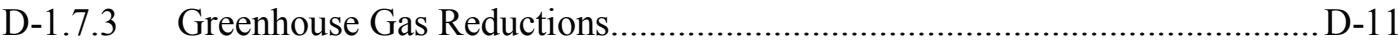

D-2. SUSTAINABILITY PROGRAM BARRIER AND GAP ANALYSIS .................................... D-12

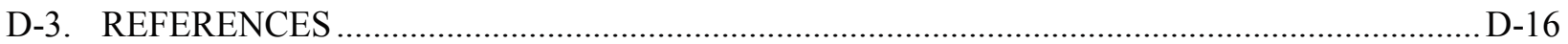

\section{FIGURES}

Figure D-1. Simultaneous excellence and sustainability principles

D-2

\section{TABLES}

Table D-1. Energy and resource efficiency project summary..............................................................

Table D-2. Buildings planned to meet Executive Order 13423 Guiding Principles................................ D-9

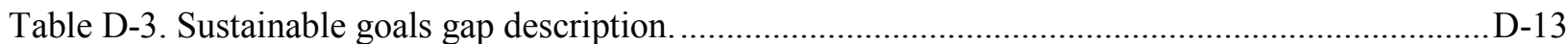




\section{APPENDIX D STRATEGIC SUSTAINABILITY PROGRAM}

\section{D-1. IDAHO NATIONAL LABORATORY STRATEGY FOR GLOBAL SUSTAINABILITY LEADERSHIP}

The DOE-NE, DOE-ID, and DOE Sustainability Performance Office (SPO) identified sustainability as a high-priority initiative with an emphasis on meeting federal energy, water, and greenhouse gas (GHG) reduction goals. INL institutionalized a strategy to implement sustainable practices in facility design and operation, procurement, and program operations that incorporate information from the following documents:

- EO 13514, Federal Leadership in Environmental, Energy, and Economic Performance

\author{
Sustainable INL
}

INL will carry out its mission of ensuring

the nation's energy security with safe,

competitive, and sustainable energy

systems without compromising the ability

of future generations to meet their own

needs.

- $\quad$ EO 13423, Strengthening Federal Environment, Energy, and Economic Performance

- DOE Order 436.1, Departmental Sustainability

- $\quad \operatorname{SSPP}(\mathrm{DOE} 2012)$

- $\quad$ SSP (DOE-ID 2012).

INL's vision for FY 2024 is to be a leading laboratory for sustainability performance in the United States and globally. Achieving sustainability means simultaneous consideration of economic prosperity, environmental quality, and social equity.

The sustainability strategy supports the long-term objective to ensure the efficient and appropriate use of laboratory lands, energy, water, and materials, as well as the services that rely upon them. INL will move beyond compliance-oriented initiatives to sustainability as the key strategy for achieving both a competitive advantage and meaningful change. This transformation sharpens INL's focus on new designs, building upgrades, and scientific research.

Sustainability principles (Figure D-1) are consistent with BEA's Strategy Roadmap approach to laboratory management, as found in the Idaho National Laboratory Policies and Standards of Performance (POL-111).

The challenge of implementing sustainability is to minimize the impact to operations while increasing the health and viability of the laboratory. INL is integrating sustainability performance improvements in the areas that matter most to its stakeholders, including minimizing the environmental footprint, taking a progressive approach to mitigating climate change, and championing energy conservation. 

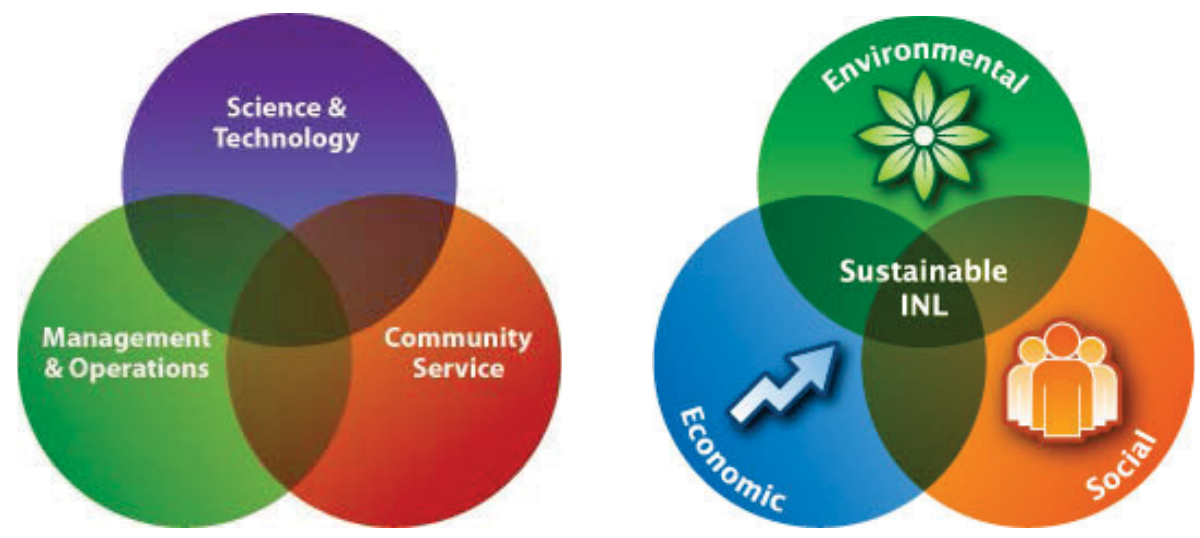

Figure D-1. Simultaneous excellence and sustainability principles.

The first step toward sustainability is to educate managers and staff about the physical, cultural, socioeconomic, and ethical dimensions of sustainability. The second step is to empower INL employees to understand and apply sustainable practices in their work activities.

To achieve this, INL is fully implementing sustainability into its culture through thoughtful consideration of all aspects of sustainable design, facility operation, and process modifications to establish sustainability as central to ongoing success as a premier national laboratory.

To meet the sustainability challenges, INL has formulated the following comprehensive strategy to address the immediate needs of its staff and facility users:

- Employ new business models to fund sustainability projects

- Ensure flexible facility design and operations meet the needs of a world-class sustainable laboratory

- Advance GHG emissions reduction efforts and adopt comprehensive policies to reduce INL's carbon footprint

- Leverage planning teams to identify and recommend strategies for maintaining sustainable reliability at minimum cost

- Synchronize world-class vehicle fueling infrastructure for government and private fueling

- $\quad$ Fully implement the SSP (DOE-ID 2012)

- Establish realistic sustainability goals and metrics that are based on legal requirements and adapted to our geographic region

- Maintain quality workplaces for employees and users through rehabilitating, renovating, and upgrading those enduring buildings that can readily support current and future missions

- Improve the energy and resource efficiency of new and existing leased facilities

- Integrate campus development with responsible regional and local planning. 
The INL Sustainability Program will continue to promote economic, environmental, and social sustainability for INL, helping to ensure its long-term success and viability. The Sustainability Program seeks to achieve measurable and verifiable energy, water, and GHG reductions. The Program is also responsible for providing strategic leadership for the entire INL Site; advancing sustainable building designs; exploring the potential use of renewable energy; reducing utility costs across INL; and supporting cost-effective facilities, services, and program management.

\section{D-1.1 Idaho National Laboratory Site Sustainability Plan}

The DOE SSPP (DOE 2012) addresses how DOE will meet the goals of the applicable "greening the government" executive orders and statutes. The SSP (DOE-ID 2012) outlines how INL will implement continual efficiency improvements directed at meeting the goals and requirements included in the SSPP. The SSP also summarizes energy and fuel use reporting requirements and references criteria for performing sustainable design. BEA, as the primary INL contractor, annually updates the SSP, adding specificity as projects are developed and requirements change.

The SSP encompasses all contractors and activities at the INL Site under the control of DOE-ID, including DOE-EM. NRF operations are excluded because NRF planning and reporting occur through the DOD. This appendix focuses on the DOE-NE/INL activities and plans from the SSP.

The SSP provides the strategy and tactics to achieve progress towards meeting the required goals but does not, on its own, guarantee success. As noted in this section, goals for fleet fuel use and GHG emissions reductions should be met or exceeded; however, additional significant resources will still be needed to develop and implement energy and water reduction projects and to increase waste diversion activities to secure success for INL in meeting all its Sustainability Program goals.

\section{D-1.2 Funding}

As a government entity, INL is limited in funding acquisition pathways. There is no standard formula for funding sustainability initiatives. However, realistic funding strategies reflect four main sources:

1. Energy Savings Performance Contracts (ESPCs)

2. Utility Energy Savings Contracts (UESCs) and utility incentive programs

3. Direct and indirect funding and reinvesting cost savings from sustainable actions

4. Special funding requests (third party, DOE-NE, line item).

A practical hybrid approach is achievable where all stakeholders participate with funding. Each of the four sources has merits and drawbacks. For example, ESPC projects can provide significant upgrades at a lower initial cost to the agency but are comprehensive and time consuming to develop. Typically, an ESPC project can take over 12 months for project development, followed by 18 months or more for design and construction.

To supplement the four sources listed, INL will request strategic investment funding to accomplish energy and resource efficiency projects that are not readily implemented with alternative funding sources (ESPC and UESC). These projects will focus on facilities that can be updated to meet the EO 13423 Guiding Principles (http://www.wbdg.org/references/mou.php). Table D-1 provides a snapshot of the projects identified for implementation to be prioritized against laboratory resources over a minimum of three fiscal years. 


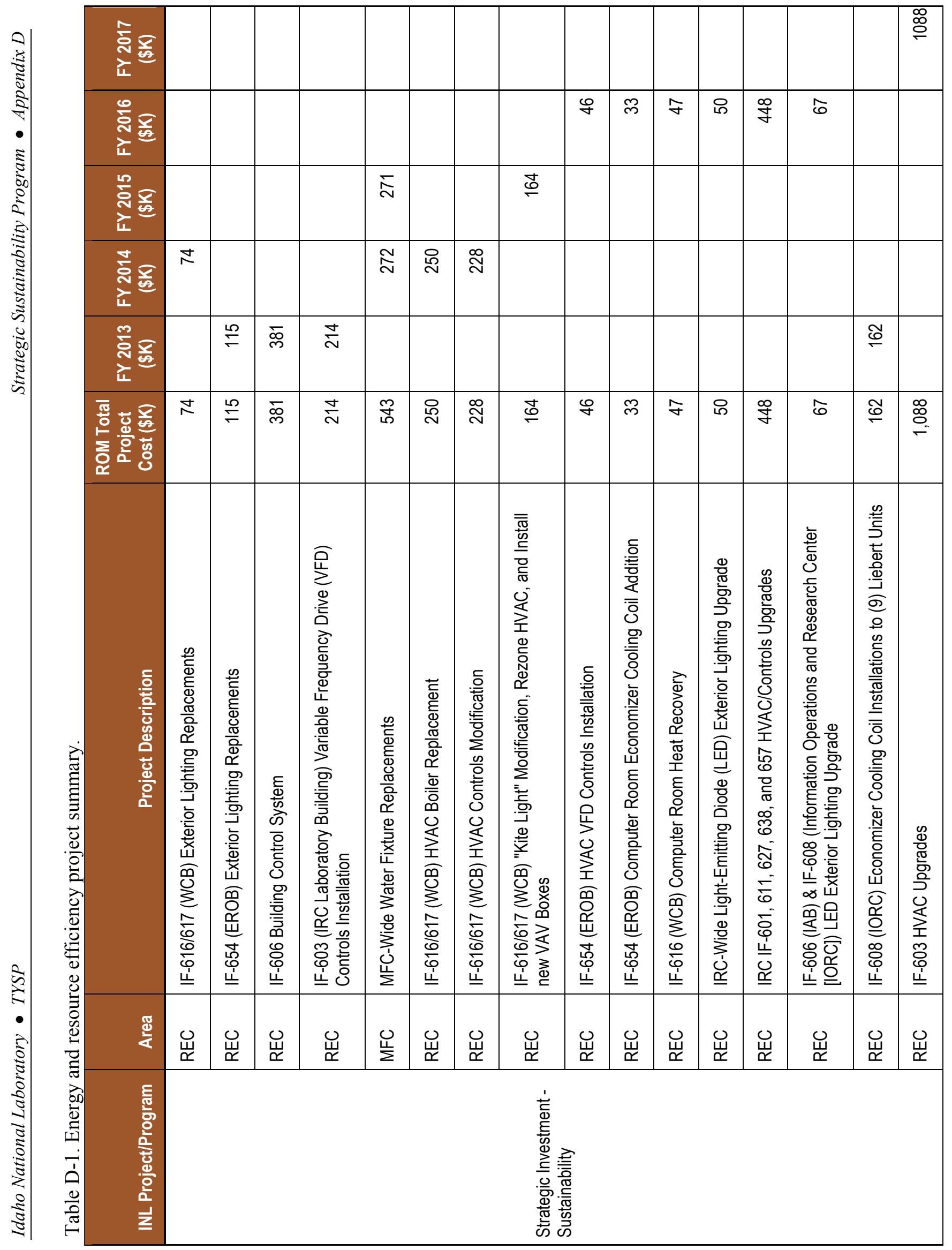




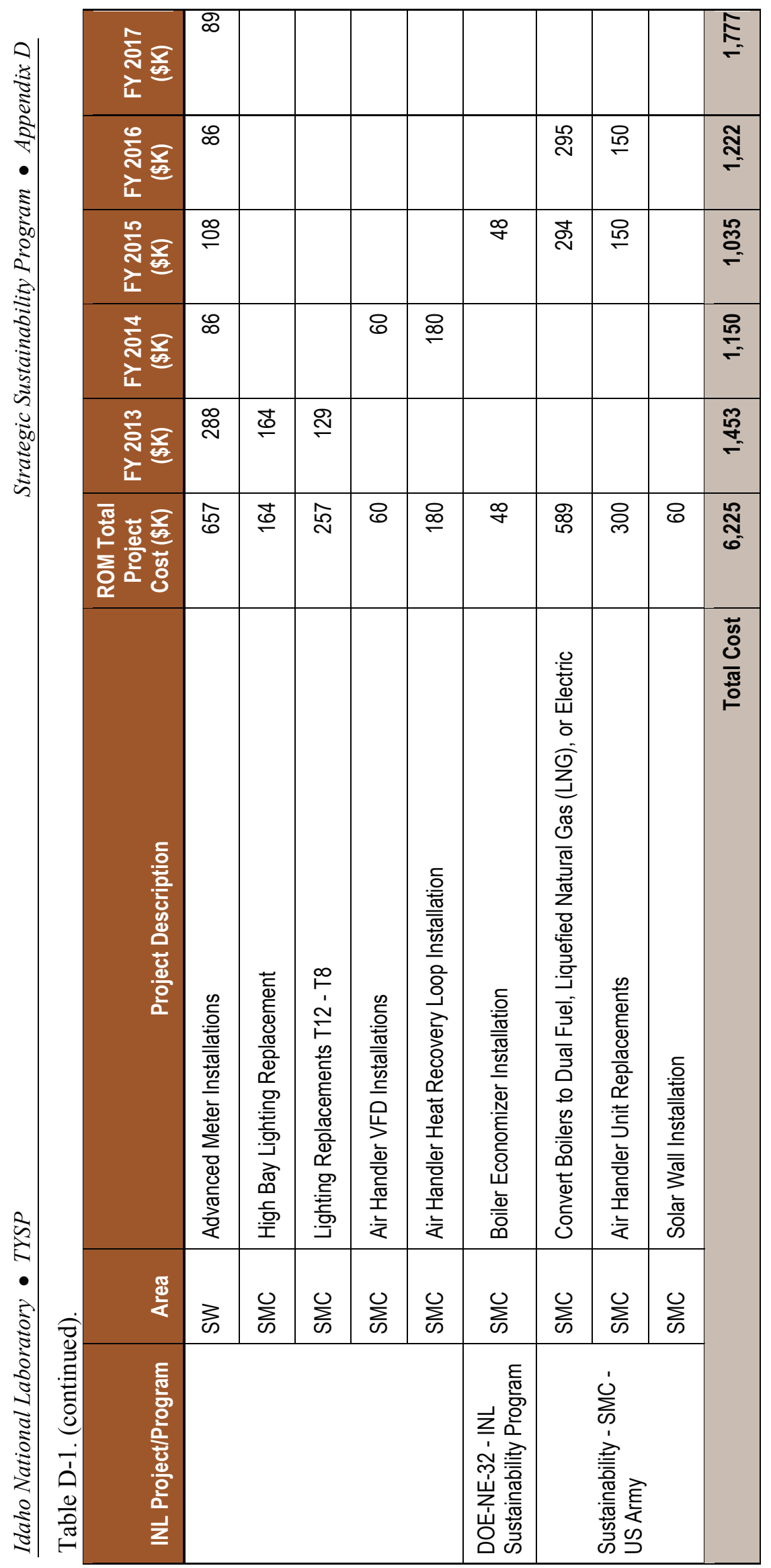




\section{D-1.3 Sustainability Goals}

INL adopted the major programmatic sustainability goals contained in the Executive and DOE Orders and the SSPP. Sustainability is a performance improvement strategy that is readily validated through performance measurement and reporting. The following subsections discuss in greater detail the primary energy, water, and fuels usage goals that are the basis for validating the performance of INL sustainability.

\section{D-1.3.1 Energy Reduction}

The INL goal for energy efficiency is a $30 \%$ reduction in energy intensity by FY 2015 as compared to the FY 2003 energy intensity baseline. On average, an annual energy use reduction goal of 3\% supports meeting the overall goal and provides a means to measure and trend progress Energy sources affected by this goal include electricity, natural gas, fuel oil, LNG, and propane. Energy intensive loads that are mission-specific are excluded from the goal, including ATR and its support facilities, but are not exempted from the responsibility to reduce energy use, where practicable. In some cases, planned facility removal has resulted in an increase in energy intensity by decreasing the total building square footage, while only minimally impacting the overall energy use. INL expects this trend to diminish as facility removal efforts end and as ESPC and strategic investment projects are completed.

Methods to reduce energy use include capital project upgrades, operational modifications, and behavior changes by the INL workforce.

The MFC ESPC project included $\$ 33$ million in energy and water saving upgrades that will provide overall energy reductions for the INL Site of 5\%. Data are being validated and systems optimized to maximize the investment.

Additional energy reductions will be obtained through implementation of strategic investment funded projects, projects funded by the Office of Facilities Management, and projects funded by the U.S. Army at SMC. These projects are listed in Table D-1.

The City of Idaho Falls upgraded all of its electrical power meters to advanced smart-meter technology. INL facilities were upgraded during the summer of FY 2012 as part of the city's initial upgrade project. INL will work to gain access to this data-collection system, which will support improved demand management capabilities.

Metering is also planned for all buildings upgraded during ESPC projects and as identified by the INL Metering Plan (PLN-3911). This Plan provides a spreadsheet for Idaho Falls and INL Site locations where metering is cost effective and will result in $90 \%$ of the total electricity at the INL Site being metered at the building level. Metering provides additional data compilation and utility management benefits. 
In addition to providing a means of trending and validating energy savings, metering also provides proactive space management opportunities. Energy and water usage information assists with electrical demand management, enhanced resource utilization, and transfer or assignment of energy costs to the user in a more accurate manner. Advanced metering provides a method to encourage and validate employee behavior change and provides a dependable tool for facility managers to optimize building systems and controls.

The critical constraint to goal accomplishment is how well INL is able to create sustained change in behavior. The strategy for behavior change was adapted from private industry and includes:

- Elevating sustainability in company governance, including Leadership Management Team oversight and accountability over environmental and social issues, and linking executive and other employee compensation to sustainability goals

- Robust regular dialogues with key laboratory stakeholders on sustainability challenges, including employees, managers, and suppliers

- Open reporting on sustainability strategies, goals, and accomplishments

- Systematic operations and performance improvements to achieve environmental neutrality and other sustainability goals across the entire INL portfolio.

\section{D-1.3.2 Water Reduction}

The INL goal for water usage is a $26 \%$ reduction of usage intensity by FY 2020, or $2 \%$ each year, as compared to the FY 2007 water-usage intensity baseline measured in gal/ $\mathrm{ft}^{2}$.

INL reports water consumption as all water pumped from the ground onsite and all water procured from the City of Idaho Falls. Water reduction opportunities are continually evaluated on a complex by complex basis each fiscal year. Additionally, water reduction opportunities (i.e., wholesale water fixture upgrades at MFC) will continue to be evaluated to increase water efficiency while addressing ongoing water waste processing issues.

In all cases, water metering will be required for installation during ESPC projects (providing for enhanced project validation) in addition to operational and maintenance tools.

\section{D-1.3.3 Fleet Fuels Reduction}

INL is developing diversified strategies for reducing fossil fuel use and carbon emissions associated with light- and heavy-duty vehicles. The DOE sustainability goals for transportation fuels include a 30\% reduction of petroleum fuel use by FY 2020 and a 100\% increase of alternative fuels by FY 2015, both as compared to the FY 2005 usage baseline.

There are many opportunities to affect DOE's petroleum fuel usage by implementing fuel reduction and fuel switching activities at INL. INL continues to meet and exceed the transportation fuel goals by actively pursuing increased E- 85 and biodiesel fuel usage. These increases are facilitated by mandating the use of alternative fuels in all flex-fuel vehicles, and by increasing the quality of biodiesel fuel while implementing the use of B20 biodiesel blend in the INL bus fleet throughout the winter season. Other strategies include continuing to right size the INL fleet, obtaining higher-efficiency hybrid and flex-fuel vehicles, and researching natural gas/biodiesel blended fueling for the INL bus fleet. 


\section{D-1.4 Carbon Footprint}

In addition to sustainability goals for energy, water, and fleet fuel reduction, DOE has committed to reduce Scope 1 (direct emissions from sources owned or controlled by INL) and Scope 2 (indirect emissions from consumption of purchased electricity, heat, or steam) GHG emissions by $28 \%$ before the end of FY 2020 as compared to the FY 2008 baseline. INL has calculated the initial FY 2008 Carbon Footprint and the FY 2012 GHG inventory annual update. Both of these calculations are found in Idaho National Laboratory's FY12 Greenhouse Gas Report (INL 2013). The GHG inventory and report support the INL initiative to lead GHG emissions-reduction efforts and is an accepted method of identifying environmental impacts by methods to reduce them.

INL will continue to implement projects that reduce electricity and fuel usage while at the same time reduce corresponding GHG emissions. Activities to reduce INL's Carbon Footprint include increasing infrastructure efficiency and switching to fuel with less GHG-intensive emissions.

The INL strategy to reduce GHG emissions also includes:

- Reduce mobile combustion from INL fleet vehicles and equipment

- Identify increased waste diversion opportunities

- Reduce the amount of direct purchased electricity

- Increase the amount of direct purchased renewable or green energy

- Reduce or eliminate fuel oil use for onsite stationary electricity and heat generation.

By FY 2013, INL will track and allocate GHG emissions on a program-by-program basis to incorporate accountability. INL updates GHG emissions reports annually.

\section{D-1.5 High Performance Sustainable Buildings}

All new construction, major renovations, and alterations of buildings greater than $5,000 \mathrm{ft}^{2}$ must comply with the EO 13423 Guiding Principles. The INL strategy for new construction is certification as LEED Gold for New Construction to document equivalency to the Guiding Principles. INL has developed a High Performance Building Strategy to assist with achieving these goals in both DOE-owned facilities and leased facilities.

At least $15 \%$ of the INL building inventory over 5,000 $\mathrm{ft}^{2}$ must meet the EO 13423 Guiding Principles by FY 2015. The Environmental Protection Agency Portfolio Manager database is the accepted tool to document and demonstrate compliance with the Guiding Principles. INL has identified 27 buildings best positioned to meet the Guiding Principles and is targeting these facilities for metering and efficiency upgrades that will help to document and meet the associated requirements. Table D-2 outlines these facilities.

\section{D-1.5.1 Sustainability in Owned Facilities}

INL addresses sustainability in both new and existing owned facilities by ensuring that the EO 13423

Guiding Principles are implemented through new building designs and through the evaluation of existing buildings for physical and operational modifications to meet the requirements. 
Table D-2. Buildings planned to meet Executive Order 13423 Guiding Principles.

\begin{tabular}{|c|c|c|c|c|c|}
\hline $\begin{array}{c}\text { Buildings } \\
\text { Planned to Meet } \\
\text { Guiding } \\
\text { Principles }\end{array}$ & Metered & $\begin{array}{l}\text { Connected to } \\
\text { the Carrier iVue } \\
\text { Building } \\
\text { Control System }\end{array}$ & $\begin{array}{l}\text { Water } \\
\text { Metered }\end{array}$ & $\begin{array}{l}\text { Guiding } \\
\text { Principle } \\
\text { Compliant }\end{array}$ & Comments \\
\hline REL & 2014 & 2014 & 2014 & 2014 & LEED Gold in FY 2014 \\
\hline ESL & Yes & Yes & Yes & 2013 & LEED Gold in FY 2013 \\
\hline IMCL & Yes & Yes & Yes & 2014 & LEED Gold in FY 2013 \\
\hline IF-665 (CAES) & Yes & No & Yes & Yes & LEED Gold \\
\hline IF-683 (RESL) & Yes & Yes & No & 2013 & LEED Gold \\
\hline TRA-1608 (TSB) & No & No & No & Yes & LEED Certified \\
\hline TRA-1626 (TTAF) & Yes & Yes & No & 2014 & LEED Certification Pending Energy Use Reductions \\
\hline IF-601 & Yes & Yes & No & 2013 & \\
\hline IF-602 & Yes & Yes & No & 2013 & \\
\hline IF-616 & Yes & Yes & Yes & 2013 & \\
\hline IF-654 & Yes & Yes & Yes & 2013 & \\
\hline IF-663 & Yes & Yes & No & 2013 & \\
\hline IF-680 & Yes & 2012 & 2013 & 2014 & Water Meter by City of Idaho Falls \\
\hline IF-684 & Yes & 2012 & 2013 & 2014 & Water Meter by City of Idaho Falls \\
\hline CF-1611 & Yes & Yes & No & 2013 & \\
\hline CF-1612 & Yes & Yes & No & 2013 & \\
\hline CF-1618 & Yes & Yes & No & 2013 & \\
\hline CF-612 & 2013 & 2013 & No & 2015 & \\
\hline CF-621 & Yes & Yes & No & 2015 & \\
\hline CF-623 & Yes & Yes & No & 2015 & \\
\hline CF-615 & 2013 & 2013 & No & 2015 & \\
\hline CF-1608 & 2013 & 2013 & No & 2015 & \\
\hline MFC-710 & Yes & 2012 & No & 2014 & \\
\hline MFC-725 & Yes & 2012 & No & 2014 & \\
\hline MFC-782 & Yes & 2012 & No & 2014 & \\
\hline TRA-628 & 2013 & 2013 & No & 2014 & \\
\hline TRA-679 & 2013 & 2013 & No & 2015 & \\
\hline
\end{tabular}


All new building projects are designed to meet the EO 13423 Guiding Principles. The INL strategy for new construction is certification as LEED Gold for New Construction to document equivalency to the Guiding Principles. The existing building inventory at INL was evaluated using DOE's Metering Guidance (DOE 2006) to determine the best candidates for building level advanced metering. Buildings meeting the criteria will have advanced meters installed and will be further evaluated for updates to meet the Guiding Principles by FY 2015. The Guiding Principles will be primarily met through documenting INL supporting processes and procedures and through planned facility upgrades.

\section{D-1.5.2 Sustainability in Leasing}

Leased buildings will be obtained that provide the best value to government; that maximize employee comfort, health, and productivity; and minimize operating and utility costs. Certification to LEED Gold for New Construction is the INL standard for design and construction of new building leases or build-tosuit leases. New leases on existing buildings will include provisions to evaluate the facility prior to occupancy for energy efficiency and the ability of the building systems to provide the appropriate indoor environmental quality. When leases on existing buildings are renewed, negotiations will include energy updates to maximize energy efficiency and employee productivity by incorporating the EO 13423 Guiding Principles. For leases intended to be very short-term temporary occupancies, the buildings will be evaluated and updated on a case-by-case basis, with a preference for a facility that demonstrates better energy efficiency and indoor environmental quality.

INL has demonstrated its commitment to these essential goals through recent building space acquisitions, including the build-to-suit ESL and REL. The ESL obtained LEED Gold certification in early FY 2013 and REL is planned for LEED Gold certification in FY 2014.

\section{D-1.6 Regional and Local Integrated Planning}

INL will seek to advance regional and local integrated planning by first incorporating LEED for New Construction into all new building designs and by seeking certification credits in areas associated with site selection and transportation planning. In addition, INL will continue active involvement with local planning organizations, including:

- Idaho Strategic Energy Alliance

- Yellowstone Business Partnership

- Yellowstone-Teton Clean Cities Coalition

- Bonneville County Transportation Committee

- City of Idaho Falls

- Targhee Regional Public Transportation Authority.

\section{D-1.7 Additional Activities Focused on 2023}

INL will continue to support energy and water efficiency reductions, transportation fuel efficiency, and GHG reductions through creative and proactive sustainable activities, which include, but are not limited to, building standards, behavior modifications, and GHG reductions. 


\section{D-1.7.1 Building Standards}

- Ensuring that all new construction and new infrastructure leases include provisions to obtain the U.S. Green Building Council LEED Gold certification, at a minimum.

- Applying the EO 13423 Guiding Principles to operations and renovations of all appropriate enduring INL infrastructure.

- Incorporating new EO 13514 requirements for net-zero facilities into design and construction of all new facility projects by FY 2020. Net-zero means that the facility generates at least as much renewable energy as the total energy it consumes.

- Providing INL campus development and planning to address effective space management, facility utilization and disposal, and operations consolidation through trending and analyzing facility utilization and utility usage data.

- Incorporating cool roof principles and technologies into all roof replacement and new construction projects.

\section{D-1.7.2 Behavior Modifications}

- Evaluating and updating INL engineering standards; the INL High-Performance Building Strategy; and other internal plans, goals, and documentation of sustainability-related activities to remain current with federal requirements and to provide engineers with practical tools to implement sustainability.

- Reviewing and analyzing new building designs, proposed changes to existing buildings, and requests for new-leased facilities to ensure the acceptance and integration of sustainable concepts.

- Actively leading and contributing to federal, Battelle Corporate, and INL working groups and communities of practice, as well as the Energy Facility Contractors Group, to influence future goals and requirements that will lead to increased efficiency, reduced emissions, and more productive infrastructure environments.

- Actively pursuing advanced metering to provide central "real-time" energy and water usage evaluation, utility-level demand-side management, and measurement tools to assist with facility management, process operation, and employee involvement.

\section{D-1.7.3 Greenhouse Gas Reductions}

- Evaluating and supporting potential onsite renewable energy construction opportunities, purchasing locally generated renewable energy, and purchasing renewable energy credits to support the growth and success of renewable energy generation industries and to reduce GHG emissions.

- Increasing the overall efficiency of the INL fleet, while focusing on increased opportunities to use alternative fuels.

- Achieving carbon neutrality for all infrastructure activities by FY 2025. 


\section{D-2. SUSTAINABILITY PROGRAM BARRIER AND GAP ANALYSIS}

Table D-3 provides a barrier and gap analysis illustrating areas where the INL Sustainability Program needs to focus efforts to ensure that goals are met.

As discussed in Section D-1.2, four primary sources of funding exist. The primary INL method of funding project opportunities remains ESPC and UESC mechanisms; however, all funding options will be pursued to reduce the gap between the various DOE SSPP (DOE 2012) requirements and the potential to meet or exceed those requirements. 


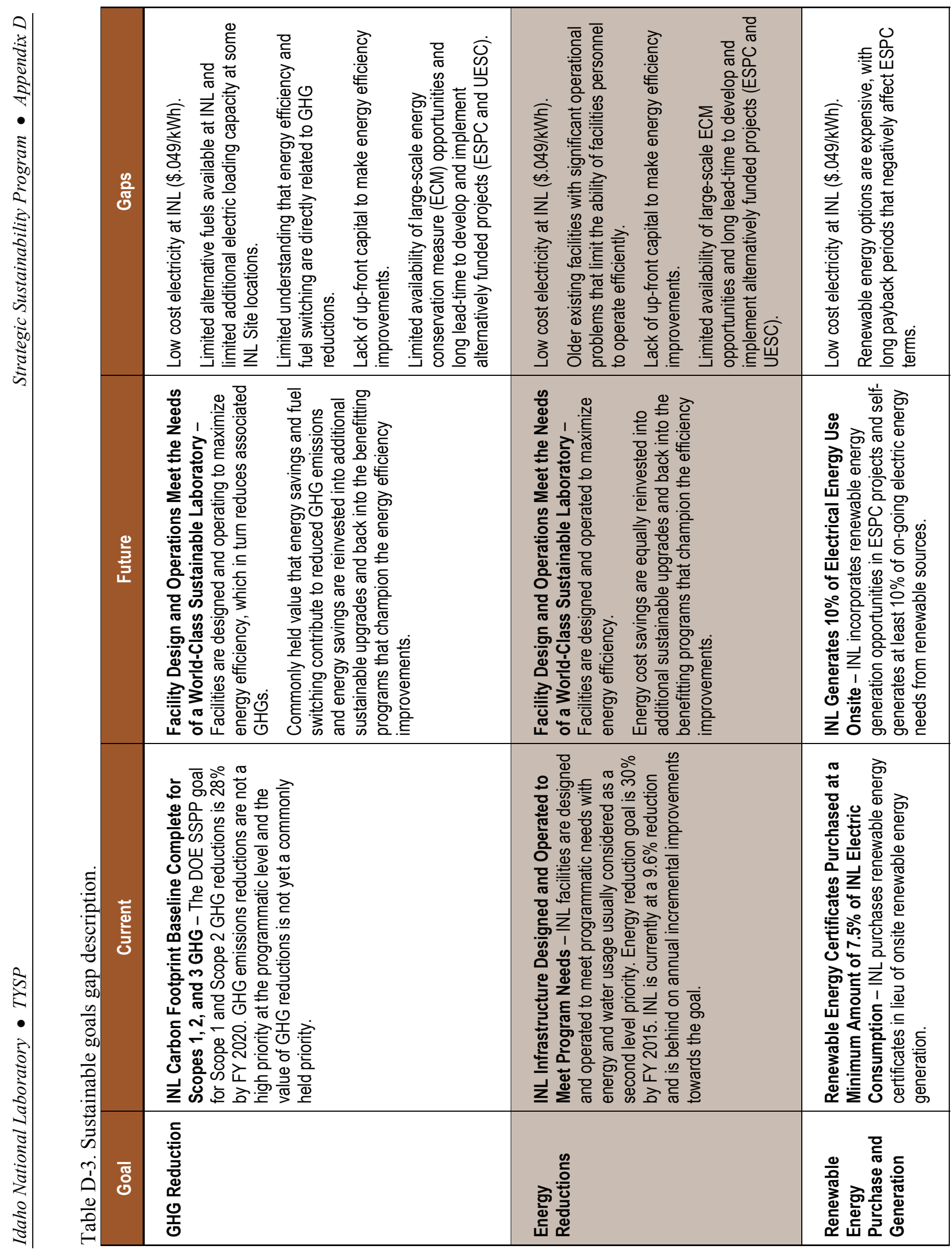




\begin{tabular}{|c|c|c|c|c|}
\hline & 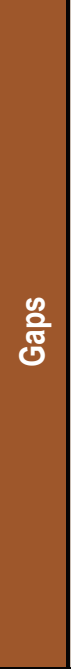 & 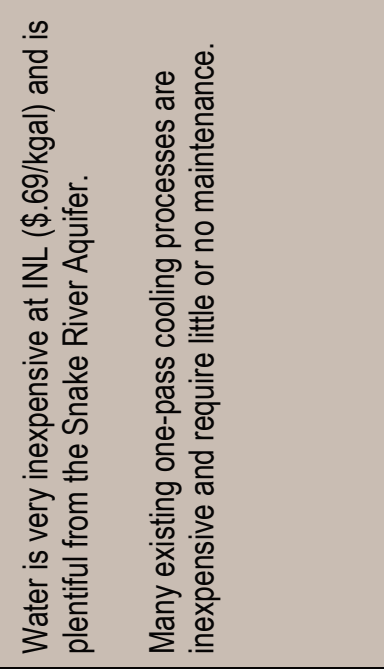 & 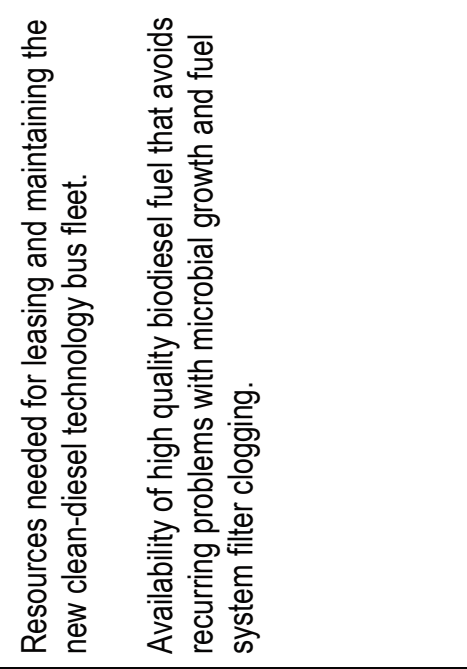 & 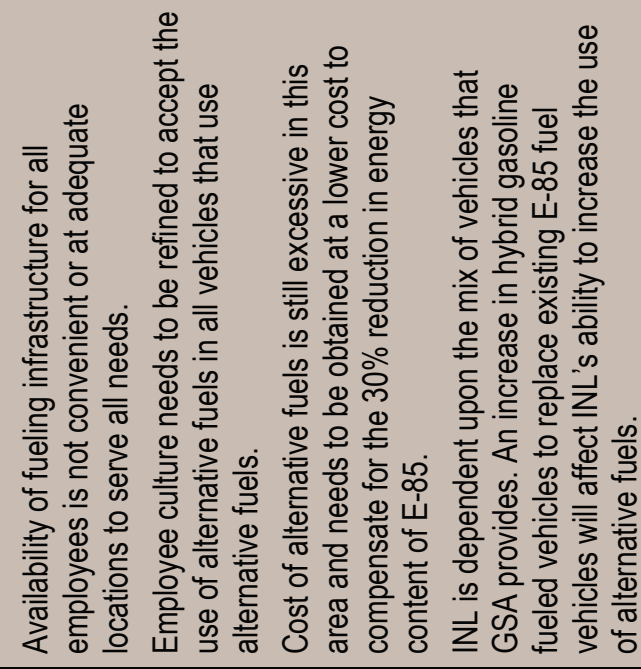 \\
\hline & 递 & 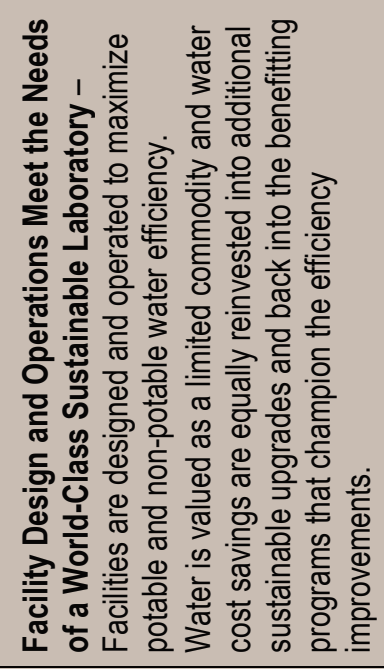 & 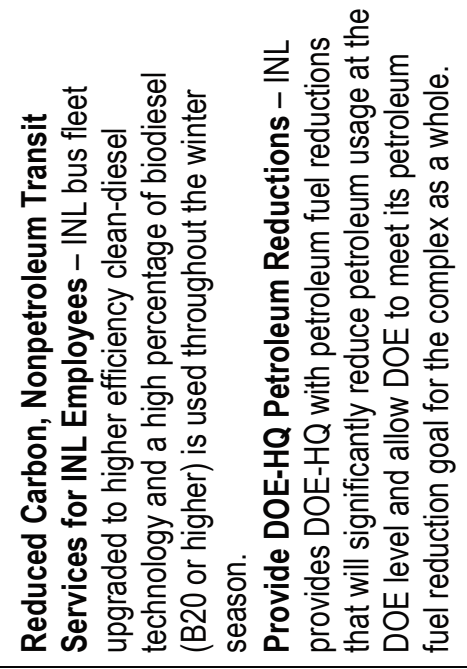 & 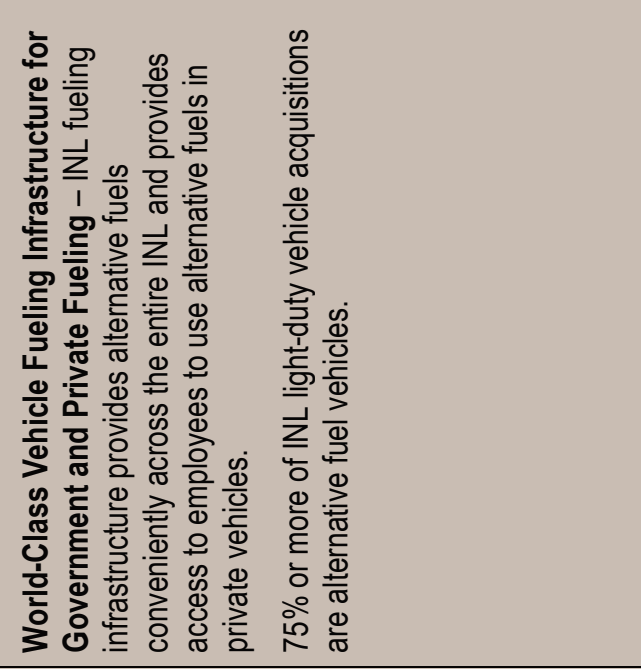 \\
\hline 兽 & 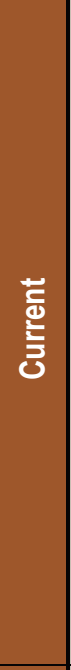 & 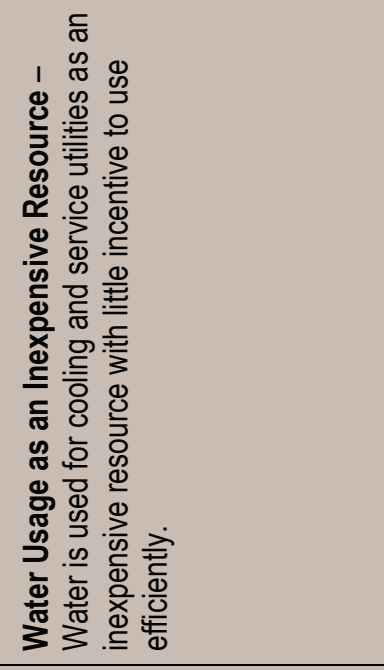 & 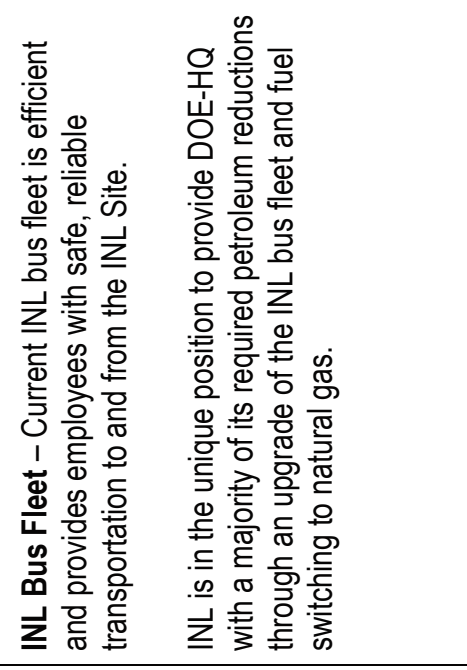 & 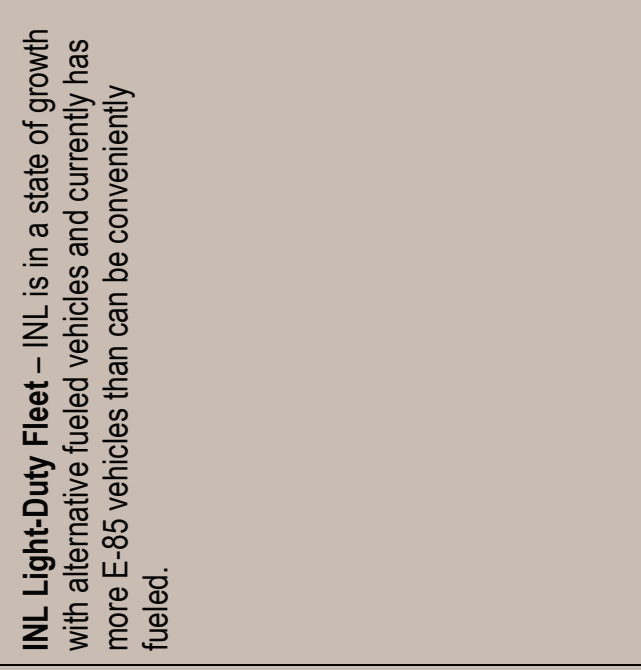 \\
\hline 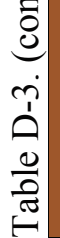 & 8̊ㅇ & 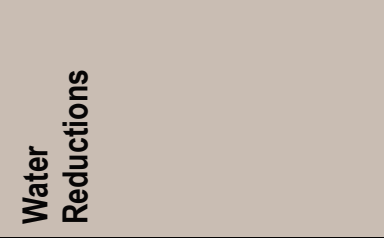 & 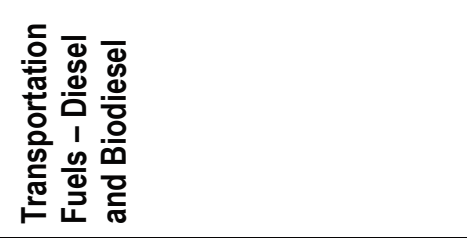 & 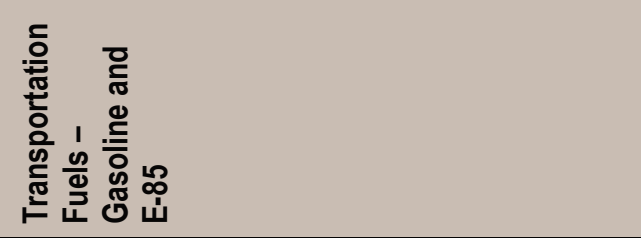 \\
\hline
\end{tabular}




\begin{tabular}{|c|c|c|c|}
\hline & 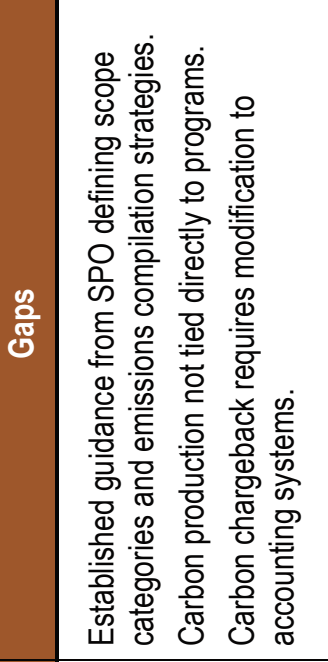 & 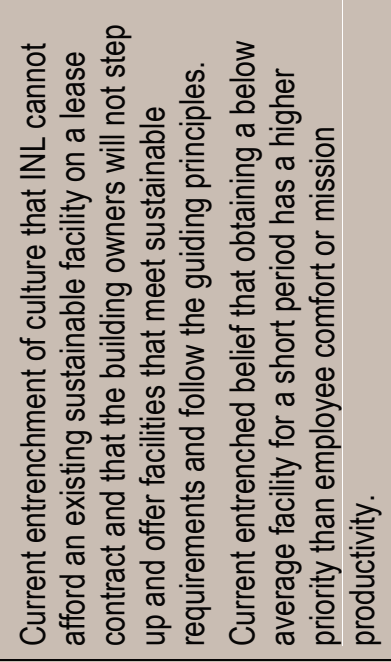 & 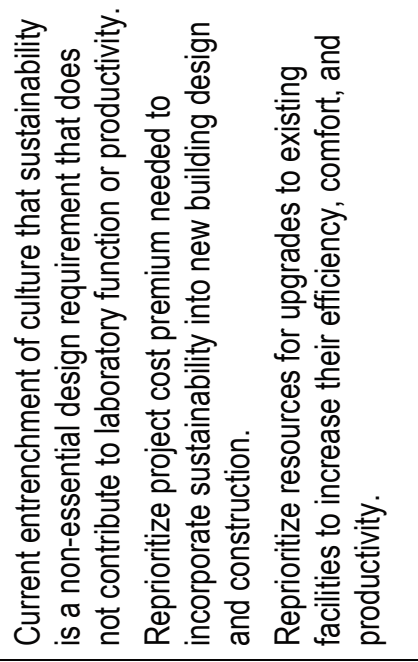 \\
\hline & 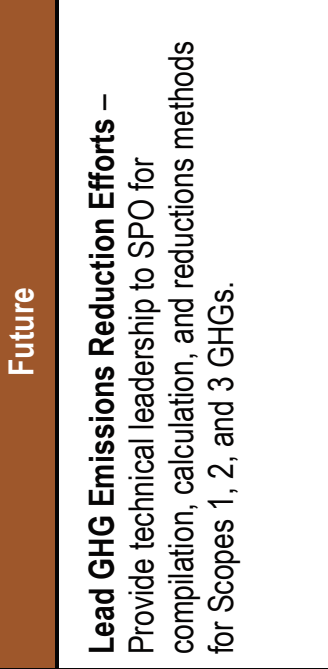 & 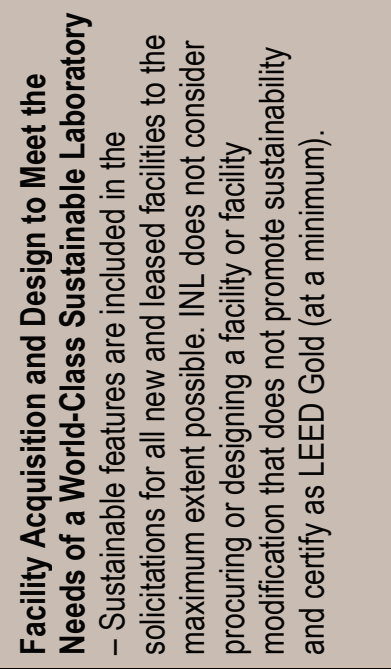 & 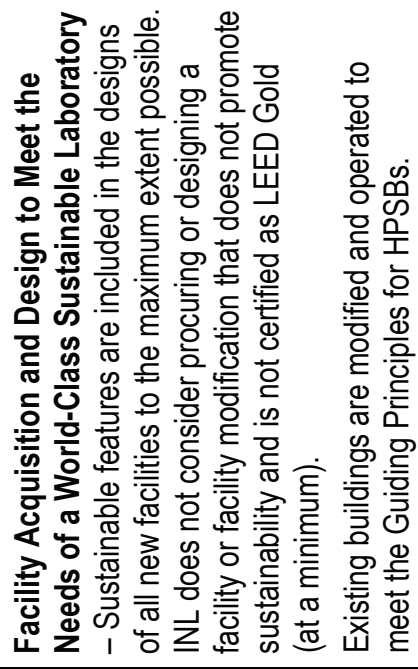 \\
\hline 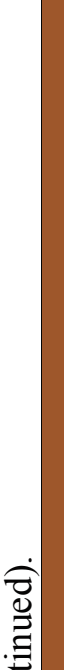 & 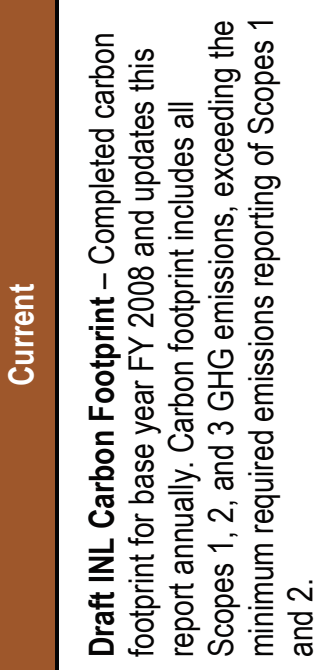 & 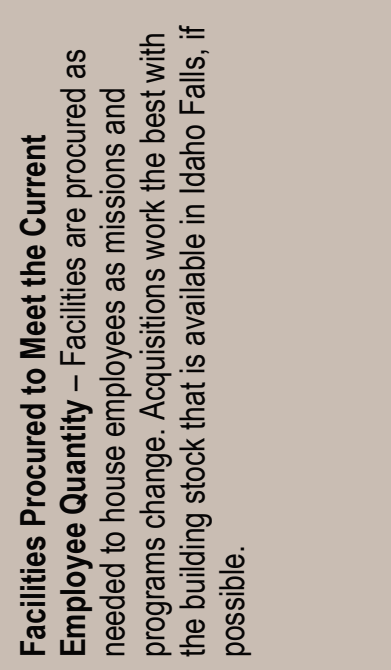 & 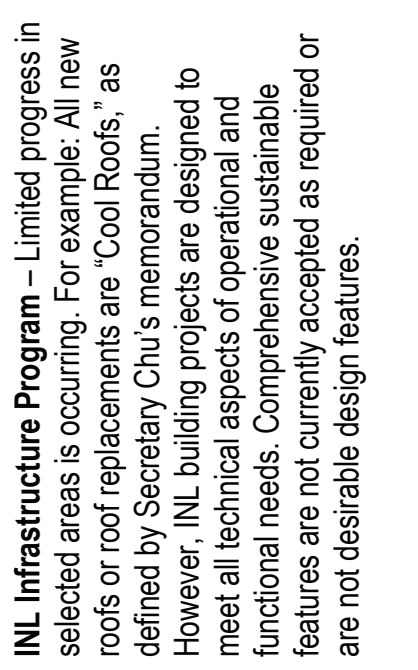 \\
\hline 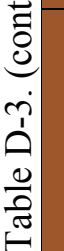 & 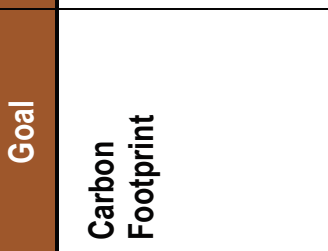 & 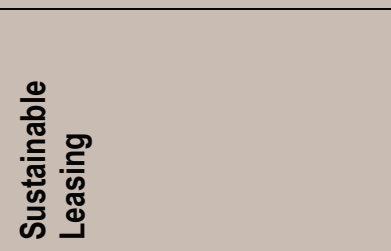 & 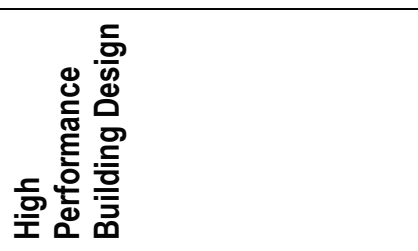 \\
\hline
\end{tabular}




\section{D-3. REFERENCES}

DOE, 2006, Guidance for Electric Metering in Federal Buildings, DOE/EE-302, Federal Energy Management Program (FEMP) and US DOE Energy Efficiency and Renewable Energy (EERE), http://www1.eere.energy.gov/femp/pdfs/adv metering.pdf, February 3, 2006.

DOE, 2012, DOE Strategic Sustainability Performance Plan, Report to The White House Council on Environmental Quality, Department of Energy, June 2012.

DOE Order 436.1, Departmental Sustainability, U.S. Department of Energy, May 2011.

DOE-ID, 2012, FY 2013 INL Site Sustainability Plan with the FY 2011 Annual Report, DOE/ID-11383, Rev. 4, Department of Energy Idaho Operations Office, December 2012.

EO 13423, Strengthening Federal Environmental, Energy, and Transportation Management, Executive Order, June 24, 2007.

EO 13514, Federal Leadership in Environmental, Energy, and Economic Performance, Executive Order, October 5, 2009.

INL, 2013, Idaho National Laboratory's FY12 Greenhouse Gas Report, INL/EXT-13-28602, Idaho National Laboratory, March 2013.

PLN-3911, INL Metering Plan, Revision 0, Idaho National Laboratory, August 1, 2011.

POL-111, Idaho National Laboratory Policies and Standards of Performance, Revision 5, Idaho National Laboratory, August 16, 2010. 


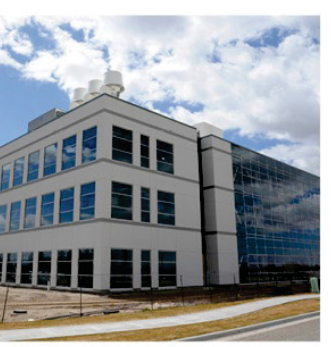

The Research Education Laboratory (REL), slated for completion in 2014, will be the research and development and National Scientific User Facility high-performance gateway to INL, supporting nudear fuel cycle research, site stewardship, research involving industrial processes, and advanced energy generation.

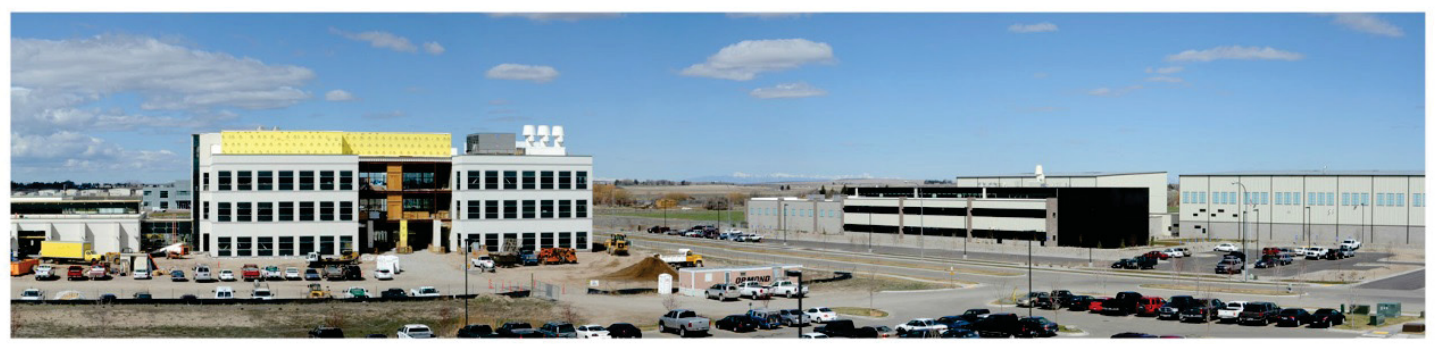

The Research and Education Campus (REC) is the collective name for INL's administrative, educational, laboratory, technical support, and computer facilities in Idaho Falls. INL is transforming infrastructure at the REC to support its mission by providing robust science and engineering capabilities.

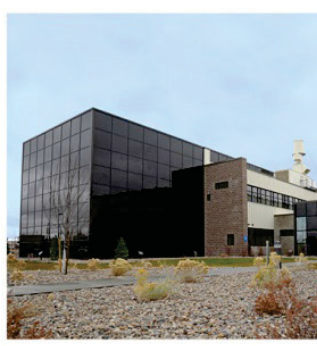

The Energy Systems Laboratory (ESL), dedicated in April 2013, provides support infrastructure to enhance the nation's global competitiveness by advancing energy security through integration of clean energy systems, advancement of energy storage technologies, and biomass design and analysis. 
